Boise State University

ScholarWorks

\title{
Tectono-Metamorphic History of the Eastern Taureau Shear Zone, Mauricie Area, Québec: Implications for the Exhumation of the Mid-Crust in the Grenville Province
}

\author{
Renaud Soucy La Roche \\ Université du Québec à Montréal \\ Félix Gervais \\ École Polytechnique de Montréal \\ Alain Tremblay \\ Université du Québec à Montréal \\ James L. Crowley \\ Boise State University \\ Gilles Ruffet \\ Université de Rennes 1
}

\section{Publication Information}

Soucy La Roche, Renaud; Gervais, Félix; Tremblay, Alain; Crowley, James L.; and Ruffet, Gilles. (2015). "Tectono-Metamorphic History of the Eastern Taureau Shear Zone, Mauricie Area, Québec: Implications for the Exhumation of the Mid-Crust in the Grenville Province". Precambrian Research, 257, 22-46.

https://doi.org/10.1016/j.precamres.2014.11.012

This is the author's version of a work that was accepted for publication in Precambrian Research. Changes resulting from the publishing process, such as peer review, editing, corrections, structural formatting, and other quality control mechanisms may not be reflected in this document. Changes may have been made to this work since it was submitted for publication. A definitive version was subsequently published in Precambrian Research, 257 (Feb 2015) doi: 10.1016/j.precamres.2014.11.012 
TECTONO-METAMORPHIC HISTORY OF THE EASTERN TAUREAU SHEAR ZONE, MAURICIE AREA, QUÉBEC: IMPLICATIONS FOR THE EXHUMATION OF THE MID-CRUST IN THE GRENVILLE PROVINCE

SOUCY LA ROCHE, Renaud ${ }^{a 1}$, GERVAIS, Félix ${ }^{b}$, TREMBLAY, Alain ${ }^{c}$, CROWLEY, James L. ${ }^{d}$, RUFFET, Gilles ${ }^{e}$

Corresponding author:

a Département des Sciences de la Terre et de l'Atmosphère and GEOTOP, Université du Québec à Montréal, C.P. 8888, succursale Centre-Ville, Montréal, Québec, Canada, H3C 3 P8. soucy_la_roche.renaud@courrier.uqam.ca, +1 438-391-2923.

${ }^{b}$ Département des Génies Civil, Géologique et des Mines, École Polytechnique de Montréal, C.P. 6079, succursale Centre-Ville, Montréal, Québec, Canada, H3C 3A7. felix.gervais@polymtl.ca

' Département des Sciences de la Terre et de l'Atmosphère and GEOTOP, Université du Québec à Montréal, C.P. 8888, succursale Centre-Ville, Montréal, Québec, Canada, H3C 3P8. tremblay.a@uqam.ca

d Department of Geosciences, Boise State University, 1910 University Drive, Boise, Idaho, USA , 837251535. jimcrowley@boisestate.edu

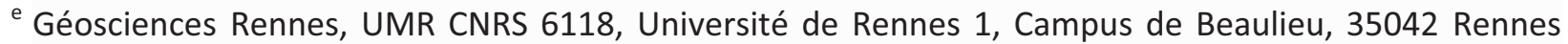
Cedex, France. gilles.ruffet@univ-rennes1.fr

Present address:

1 Department of Geological Sciences \& Geological Engineering, 36 Union Street, Queen's University, Kingston, Ontario, Canada, K7L 3N6. 13rsIr@queensu.ca. +1 438-391-2923. 


\section{Abstract}

This study investigates the tectono-metamorphic history and exhumation mechanisms of the midcrustal Mékinac-Taureau domain of the Mauricie area, central Grenville Province. Macro- and microstructural analyses reveal the top-down-to-the-ESE sense of shear on the eastern Taureau shear zone, a major extensional structure that exhumed the mid-crustal Mékinac-Taureau domain and juxtaposed it against the lower grade rocks of the Shawinigan domain. Peak metamorphism in the Mékinac-Taureau domain, inferred to be the result of northwestward thrusting and regional crustal thickening, took place under P-T conditions of $1000-1100 \mathrm{MPa}$ and $820-880^{\circ} \mathrm{C}$ prior to $1082 \pm 20 \mathrm{Ma}$. Retrograde conditions varying from 775 to $675{ }^{\circ} \mathrm{C}$ and from 800 to $650 \mathrm{MPa}$ were registered in its upper structural levels prior to and/or during shearing along the the eastern Taureau shear zone that was active at $1064 \pm 15 \mathrm{Ma}$. The Shawinigan domain records P-T conditions ranging from 850 to $625 \mathrm{MPa}$ and from 775 to $700{ }^{\circ} \mathrm{C}, \mathrm{P}-\mathrm{T}$ values that are similar to or slightly lower than those for retrogressed samples from the upper structural levels of the Mékinac-Taureau domain, but clearly lower than the peak metamorphism values of the latter domain. Finally, the area cooled below $550-600{ }^{\circ} \mathrm{C}$ at $1000-1030 \mathrm{Ma}$ and below $450{ }^{\circ} \mathrm{C}$ at $~ 900-$ $970 \mathrm{Ma}$ on the basis of ${ }^{40} \mathrm{Ar} /{ }^{39} \mathrm{Ar}$ geochronology on amphibole and biotite. Structural and metamorphic characteristics of the Mauricie area are similar to those expected from a metamorphic core complex formed during post-convergence orogenic collapse in a gravity-driven fixed-boundary mode. The Mékinac-Taureau and Shawinigan domains were thus probably exhumed by a similar process, which supports the orogenic collapse model recently proposed to explain the exhumation of mid-crustal metamorphic core complexes in the Grenville Province.

Keywords: Grenville Province; Eastern Taureau shear zone; Middle crust exhumation; Geochronology; Thermobarometry 


\section{Introduction}

In collisional orogens, the mechanisms by which high-grade metamorphic rocks are exhumed (i.e. displaced towards Earth's surface; England and Molnar, 1990) by mechanisms are central to many debates (e.g. Gapais et al., 2009; Gervais and Brown, 2011; Ring et al., 1999). For instance, mid-crustal units can be exhumed by syn-convergent channel flow coupled to focused erosion (e.g. Beaumont et al., 2001, 2006), by post-convergent orogenic collapse (e.g. Dewey, 1988; Rey et al., 2001) and associated metamorphic core complexes (MCC) development (e.g. Brun et al., 1994; Rey et al., 2009; Tirel, 2004; Tirel et al., 2004, 2006, 2008), by diapirism (e.g. Calvert et al., 1999; Teyssier and Whitney, 2002), and in orogenic wedges whose shape is described by the critical taper theory (e.g. Dahlen, 1990; Platt, 1986).

These mechanisms have all been proposed to explain the exhumation of mid-crustal units during the late Mesoproterozoic to early Neoproterozoic Grenvillian orogeny. The Grenville Province represents the southeastern boundary of Proterozoic Laurentia and the Grenvillian orogeny is characterized by a $>100$ m.y. period of heating and crustal thickening that affected a wide area of reworked Laurentian orogenic crust (>600 km; Hynes and Rivers, 2010; Rivers, 2008, 2009, 2012; Rivers et al. 2012). Recent work demonstrated that the orogenic crust can be subdivided into lower, mid and upper crustal segments (Rivers, 2008, 2012 and references therein), contrasting with the long-lasting interpretation of this province as a homogeneous slice through the mid-crust, and thus promoting research on orogenic collapse mechanisms. Following the idea of Dewey (1988), Rivers (2008) suggested the presence of a Tibetan-type orogenic plateau in the hinterland of the orogeny that resulted from thickening of the continental crust. In such a setting, the mid-crust is typically weakened by partial melting at depth (Rosenberg and Handy, 2005) and may flow laterally (Rey et al., 2001; Royden, 1996; Vanderhaeghe et al., 2003). The importance of ductile flow in the mid-crust of the Grenville orogen was assessed recently (Jamieson et al., 2007, 2010; Rivers, 2008, 2009), and a heterogeneous channel flow model, in which the weak ductile layer is thrust above a strong indentor, was proposed (Jamieson et al., 2007, 2010). A complementary model of exhumation (Rivers, 2008, 2012) presents the Grenville Province as a series of high-grade mid-crustal core complexes overlaid by fragments of the upper crust resulting from the collapse of the orogenic plateau, following crustal thickening and mid-crustal flow. Multiple regions of the Grenville Province that exhibit normal-sense faults and shear zones juxtaposing 
the potential mid-crustal core complexes with upper crustal segments were recognized by Rivers (2008, 2009, 2012). These regions include large parts of the northeastern Grenville Province, the southeastern Composite Arc Belt, the northwestern Frontenac-Adirondack Belt and smaller areas such as the Natashquan domain and the Mauricie area (Fig. 1). Finally, in a few specific localities in the eastern Grenville Province, diapirism has been proposed to explain the exhumation of high grade gneiss domes

(e.g. Gervais et al., 2004), and the orogenic wedge model has been invoked to explain the formation and exhumation of a mid-crustal foreland fold-thrust belt (van Gool et al., 2008).

This contribution presents new data from the Mauricie area to further investigate the exhumation of a mid-crustal high-grade gneiss dome known as the Mékinac-Taureau domain (Nadeau and Brouillette, 1994, 1995). Detailed macro- and micro-structural analyses reveal the kinematic history of the eastern Taureau shear zone (TSZ), a major regional structure responsible for the exhumation of the Mékinac-Taureau domain. Thermobarometry was applied to six selected samples in order to evaluate the peak pressure and temperature (P-T) conditions and the retrograde path of the Mékinac-Taureau and overlying Shawinigan domains. Both the timing of peak metamorphism and exhumation were constrained by U-Pb geochronology on zircon from two pegmatite dykes. ${ }^{40} \mathrm{Ar} /{ }^{39} \mathrm{Ar}$ thermochronology on amphibole and biotite separates from six samples was undertaken to provide precise timing constraints for the cooling of this area through the closure temperatures of these minerals. These structural, thermobarometric and geochronologic constraints were then compared with equivalent data determined from type localities in well-known orogenic belts or predicted by analog/numerical modeling of different exhumation processes to constrain the most likely process for the Mauricie area.

\section{Geological setting}

The Grenville Province comprises rocks of southeastern Laurentia that were affected by multiple orogenic events from late Paleoproterozoic until early Neoproterozoic (Hynes and Rivers, 2010; Rivers, 1997; Rivers et al. 2012). The Grenvillian orogeny is the youngest of these and can be separated into two main phases according to their age and spatial extent (Rivers, 1997, 2008; Rivers et al. 2012). The Ottawan phase affected the hinterland of the Grenville Province during a first pulse of compression from 1090 to $1020 \mathrm{Ma}$. The rocks affected by this orogenic phase are far-travelled with respect to the Laurentian margin and are referred to as allochthonous belts. This contrasts with the structurally underlying parautochthonous belt, located to the northwest, which comprises rocks of the Laurentian 
NOTICE: this is the author's version of a work that was accepted for publication in Precambrian Research. Changes resulting from the publishing process, such as peer review, editing, corrections, structural formatting, and other quality control mechanisms may not be reflected in this document. Changes may have been made to this work since it was submitted for publication. A definitive version was subsequently published in Precambrian Research, 257, (Feb 2015). doi: 10.1016/j.precamres.2014.11.012

margin that can be correlated with the Grenvillian foreland in the adjacent Archean and Proterozoic Superior provinces. The latter belt was deformed and metamorphosed during a second phase of compression, known as the Rigolet, between 1000 and 980 Ma. Rivers $(2008,2012)$ subdivided the allochthonous hinterland affected by the Ottawan orogeny into four belts according to their relative positions in the crust (Fig. 1). From base to top, (1) the allochthonous high-pressure belt (aHP Belt) comprises nappes of relict eclogitic material overprinted by granulite-facies metamorphism. The aHP belt is directly underlain by the Allochthon Boundary Thrust in two areas of the western and central Grenville Province. The aHP belt represents remnants of the base of the doubly-thickened orogenic crust that have been incorporated into the mid crust during their exhumation. (2) The allochthonous mediumpressure belt (aMP Belt) is the most extensive belt, extending along the whole length of the Grenville Province. It is composed of upper amphibolite- to granulite-facies mid-crustal units of various compositions that are commonly migmatitic. The upper crust is preserved as two distinct levels, (3) the allochthonous low-pressure belt (aLP Belt) and (4) the Ottawan Orogenic Lid (OOL). The aLP Belt is exposed only in small areas of the southeastern, central and western Grenville Province. It consists of greenschist to amphibolite-facies rocks that were juxtaposed to the aMP Belt via extensional shear zones. Finally, the structurally overlying $\mathrm{OOL}$ occupies large zones of the northeast and southwest Grenville Province. It comprises units that escaped penetrative Ottawan metamorphism and deformation, although they may have been subjected to older tectono-metamorphic episodes.

\section{Regional geology}

The present study is located in the Mauricie area, central Grenville Province, comprising rocks of the aMP and aLP belts that have been subdivided into three main lithotectonic domains (Figs. 1 and 2; Nadeau and Brouillette, 1994, 1995; Nadeau and Corrigan, 1991). (1) The domal-shaped MékinacTaureau domain is the structurally lowest domain that extends for more than $80 \mathrm{~km}$ from the St. Maurice River to the Taureau Reservoir. Its northern boundary is not yet recognized, but it is in tectonic contact to the west, south and south-east with the overlying Morin Terrane along the TSZ. (2) The Morin Terrane is principally exposed on the western side of the Mékinac-Taureau domain, but a thin slice of this terrane extends towards the east where it is referred to as the Shawinigan domain (e.g. Corrigan, 1995; Corrigan and van Breemen, 1997; Rivers, 2008). (3) To the east, the elongate, north-south striking Portneuf-Mauricie domain structurally overlies the two other lithotectonic domains along the 
NOTICE: this is the author's version of a work that was accepted for publication in Precambrian Research. Changes resulting from the publishing process, such as peer review, editing, corrections, structural formatting, and other quality control mechanisms may not be reflected in this document. Changes may have been made to this work since it was submitted for publication. A definitive version was subsequently published in Precambrian Research, 257, (Feb 2015). doi: 10.1016/j.precamres.2014.11.012

Tawachiche shear zone. These three lithotectonic domains can be distinguished according to their lithology, age, structural style and magnetic signature (Corrigan, 1995; Nadeau and Brouillette, 1994, 1995; Nadeau and Corrigan, 1991).

\subsection{Lithotectonic domains}

\subsubsection{Mékinac-Taureau domain}

The Mékinac-Taureau domain is mostly composed of 1370 Ma granodioritic orthogneiss (age from Nadeau and van Breemen, unpublished data, reported in Corrigan and van Breemen, 1997) that forms part of the aMP Belt of Rivers (2008). It is mostly at granulite facies, but upper amphibolite-facies gneiss occurs in the Reservoir Taureau area of the Mékinac-Taureau domain (Nadeau and Brouillette, 1995). According to Corrigan and van Breemen (1997), the metamorphism occurred from 1120 to 1090 Ma and was due to crustal thickening during northwestward thrusting structurally above the present exposure of units.

The Mékinac-Taureau domain orthogneiss is generally homogeneous on the map scale, but varies between granodioritic, granitic, dioritic and gabbroic compositions in any one outcrop (Nadeau and Brouillette, 1995). Felsic and intermediate gneiss is pervasively migmatitic, whereas migmatitic mafic gneiss is only locally present. Rare, discontinuous layers of quartzite, calc-silicate gneiss, marble and Sil$\mathrm{Kfs}$-Grt-bearing, migmatitic metapelite, commonly concordant to the regional foliation, are found close to the eastern margin of the Mékinac-Taureau domain (mineral abbreviations after Kretz, 1983).

Field observations in this study confirmed the general structural pattern outlined on Nadeau and Brouillette's $(1994,1995)$ compilation maps. A regional foliation $\left(S_{n}\right)$, defined by preferred orientation of minerals, ribbon quartz, gneissic compositional banding and stromatic layers of leucosome, gently dips towards the margins of the domain, although local variations occur (Fig. 2). In the interior of the domain, marble layers record high qualitative strain, as evidenced by numerous sheath folds and contorted to rounded fragments of country rocks. They were interpreted as tectonic breccias by Nadeau and Brouillette (1995). Hanmer (1988) attributed similar structures to the relatively low viscosity of marble at high temperature and pressure as compared to the surrounding gneiss. The stretching and mineral lineations $\left(L_{n}\right)$ are generally poorly developed in the interior of the domain (Fig. 2). On the southern and southeastern boundaries, a well-developed stretching lineation plunges gently to moderately $\left(10-35^{\circ}\right)$ to the ESE ( $\left.L_{n+1}\right)$ (Fig. 2). A third population of lineation $\left(L_{n+2}\right)$ plunging gently $\left(0-20^{\circ}\right)$ to the NE is recognized 
NOTICE: this is the author's version of a work that was accepted for publication in Precambrian Research. Changes resulting from the publishing process, such as peer review, editing, corrections, structural formatting, and other quality control mechanisms may not be reflected in this document. Changes may have been made to this work since it was submitted for publication. A definitive version was subsequently published in Precambrian Research, 257, (Feb 2015). doi: 10.1016/j.precamres.2014.11.012

on the eastern side along the Tawachiche shear zone (Fig. 2). Geochronological constraints suggest that $L_{n+1}$ is younger than $L_{n}$ (see section 6), whereas cross-cutting relationships imply that $L_{n+2}$ is younger than $L_{n}$ (Nadeau and Brouillette, 1994). However, there is no clear cross-cutting relationship between $L_{n+1}$ and $L_{n+2}$, thus this notation does not imply an age sequence.

\subsubsection{Morin Terrane (including the Shawinigan domain)}

The Morin Terrane comprises granulite-facies gneiss and plutonic complexes belonging to the aMP Belt (Rivers, 2008). The western side of the Morin Terrane comprises 1330 Ma orthogneiss (Peck, 2012), amphibolite, quartzofeldspathic gneiss, paragneiss, quartzite and marble (Martignole, 1975) metamorphosed at granulite-facies prior to the intrusion of the Morin and Lac Croche plutonic complexes (1165-1135 Ma; Barton and Doig, 1972; Doig, 1991; Friedman and Martignole, 1995). A second granulite-facies metamorphic event followed the intrusions, but is otherwise temporally unconstrained (Peck et al., 2005). In contrast to the granulite-facies west-side, the eastern side of the Morin Terrane, referred to as the Shawinigan domain, is characterized by the presence of upper amphibolite-facies rocks (Corrigan, 1995; Lévesque, 1995). The metamorphism is coeval with the 11201090 Ma metamorphism in the Mékinac-Taureau domain (Corrigan and van Breemen, 1997).

The Shawinigan domain is composed of two major rock units in tectonic contact: felsic to intermediate orthogneiss of the Jésuite complex and the overlying St. Boniface paragneiss. Orthogneiss of the Jésuite complex is mainly tonalitic in composition, with a crystallization age of $1370 \mathrm{Ma}$ (Corrigan and van Breemen, 1997), but granitic and rare gabbroic rocks are present locally. Stromatic migmatite is common, although not as pervasive as it is in the upper structural levels of the Mékinac-Taureau domain. The St. Boniface paragneiss comprises mainly Sil-Kfs-Grt-bearing, migmatitic metapelite with minor quartzite and marble that were deposited after $1180 \mathrm{Ma}$ on the basis of limited detrital zircon data (Corrigan and van Breemen, 1997).

Important masses of anorthosite-mangerite-charnockite-granite (AMCG), gabbro, porphyritic granite and monzonite intruded the Morin Terrane during two episodes of magmatism (Corrigan and van Breemen, 1997). The first episode includes the 1165-1135 Ma Morin anorthositic complex (Doig, 1991; Friedman and Martignole, 1995), the 1140 Ma Lac Croche complex (Barton and Doig, 1972) and the 1153 Ma Lake Paul granite (Corrigan and van Breemen, 1997). The second pulse of magmatism occurred from 1080 to $1056 \mathrm{Ma}$ and includes the Shawinigan norite, the Lejeune complex and the St. 
Didace complex (Corrigan and van Breemen, 1997; Nadeau and van Breemen, 2001).

The foliation in the Morin Terrane generally dips away from the contact with the MékinacTaureau domain. However, multiple folds described in Nadeau and Brouillette (1995) produce local variations to this trend. The regional structural pattern is also affected by pre-1135 Ma AMGC plutons that are wrapped by the foliation (Martignole, 1975; Nadeau and Brouillette, 1995). In the Shawinigan domain, the foliation $\left(S_{n}\right)$ defined by compositional banding dips shallowly to moderately $\left(0-45^{\circ}\right)$ to the SE (Fig. 2). The stretching and mineral lineations $\left(L_{n}\right)$ plunge sub-horizontally to gently $\left(0-15^{\circ}\right)$ to the $S$ and SE (Fig. 2).

\subsubsection{Portneuf-Mauricie domain}

The Portneuf-Mauricie domain comprises the 1450 Ma Montauban Group supracrustal rocks and the 1400-1370 Ma La Bostonnais calc-alkaline complex plutonic rocks (Corrigan and van Breemen, 1997; Nadeau and Brouillette, 1995; Nadeau and van Breemen, 1994). Rocks of the Portneuf-Mauricie domain are generally at a lower metamorphic grade than the other domains, with middle to upper amphibolitefacies recorded throughout most of the domain, except for the eastern strand where low- to medium-P granulite-facies is observed (Corrigan, 1995; Lévesque, 1995). Metamorphism of the Portneuf-Mauricie domain is associated with the $\sim 1400$ Ma pre-Grenvillian accretion of the Montauban Arc and was not overprinted by granulite facies metamorphism during the Grenvillian orogeny, as opposed to the adjacent Mékinac-Taureau and Shawinigan domains (Corrigan, 1995; Corrigan and van Breemen, 1997). Therefore, Rivers (2012) included the Portneuf-Mauricie domain in the aLP Belt.

The structure of the Portneuf-Mauricie domain is characterized by a planar fabric dipping gently to moderately to the SE or E and by two sets of mineral and stretching lineations (Nadeau and Brouillette, 1994, 1995). The first set is pervasive, plunges to the SE and has been attributed to regional NW-directed thrusting (Nadeau and Brouillette, 1995). The second set plunges to the NNE and was developed in discrete shear zones during oblique-sinistral extensional ductile shearing after the peak of metamorphism (Nadeau and Brouillette, 1995).

\subsection{Lithotectonic boundaries}

The contact between the Mékinac-Taureau domain and the Morin Terrane is known as the Taureau shear zone (TSZ; Fig. 1; Martignole and Friedman, 1998). On the western flank of the dome the 
NOTICE: this is the author's version of a work that was accepted for publication in Precambrian Research. Changes resulting from the publishing process, such as peer review, editing, corrections, structural formatting, and other quality control mechanisms may not be reflected in this document. Changes may have been made to this work since it was submitted for publication. A definitive version was subsequently published in Precambrian Research, 257, (Feb 2015). doi: 10.1016/j.precamres.2014.11.012

shear zone is presumed to be several hundred of meters wide and to gently dip away from the MékinacTaureau domain. Martignole and Friedman (1998) proposed oblique thrusting on the TSZ based on local dextral kinematic indicators observed on lineations shallowly plunging to the SE and because of the broad spatial coincidence between the trace of the shear zone and the Opx-in isograd (Schriver, 1973), delimiting granulite-facies rocks of the Morin Terrane from upper amphibolite-facies rocks of the western part of the Mékinac-Taureau domain. They constrained the minimum age of displacement on the TSZ by dating a late-kinematic dyke at $1074 \pm 4$ Ma. Further east, however, the eastern TSZ does not superpose granulite-facies rocks on top of amphibolite-facies rocks because the Opx-in isograd crosscuts the Mékinac-Taureau domain boundary (Fig 1; Hocq and Dufour, 1999, 2002). In the study area on the eastern flank of the dome, the metamorphic contrast across the TSZ is ambiguous, but previous qualitative observations of metamorphic mineral assemblages and textures, as well as quantitative thermobarometry studies, suggested higher grade in the footwall (Mékinac-Taureau domain) than in the hanging wall (Shawinigan domain) (Corrigan, 1995; Lévesque, 1995; Nadeau and Brouillette, 1995). If the suggested metamorphic contrast is real and if timing of metamorphism is the same for both the Mékinac-Taureau and Shawinigan domains, the two hypotheses are paradoxical: thrusting alone along the eastern TSZ could not explain the present configuration. One objective of the current study is, therefore, to test this hypothesis.

Away from the TSZ, the contact between the Portneuf-Mauricie domain and the Shawinigan domain is marked by an anastomosing array of E-dipping shear zones, collectively known as the Tawachiche shear zone (Fig. 1; Corrigan, 1995; Corrigan and van Breemen 1997; Lemieux, 1992). The total thickness of the area affected by these shear zones may be as wide as $25 \mathrm{~km}$, but most of the shearing occurred directly at the contact between the two domains, along a strand that has an average map width of $1 \mathrm{~km}$ (Corrigan, 1995). The Tawachiche shear zone is almost co-planar with the N to NE striking and gently dipping regional foliation of the Portneuf-Mauricie domain. The associated stretching lineation trends to the NNE with a shallow to moderate plunge $\left(L_{n+2}\right)$. Corrigan (1995) observed a paleopressure offset of 200 to $300 \mathrm{MPa}$ between footwall and hanging wall metamorphic mineral assemblages, with lower pressure in the hanging wall, and therefore suggested that the shear zone accommodated a vertical offset of 7-10 km by top-down-to-the-NNE oblique extensional shearing. Corrigan and van Breemen (1997) constrained the timing of movement along the Tawachiche shear zone between 1065 and $1035 \mathrm{Ma}$. 


\section{Structural geology of the eastern TSZ}

One of the main objectives of this study was to constrain the kinematic history the TSZ. Field work involved examination of over 200 outcrops from the Mékinac-Taureau domain and the Shawinigan domain, especially in the vicinity of the TSZ. Large (commonly $>500 \mathrm{~m}^{2}$ ) and well exposed key outcrops (e.g. Fig. 3A) were studied in detail to document complex structural relationships. Due to poor exposure on the western and south flank of the Mékinac-Taureau domain, the TSZ was only recognized on the eastern flank. Field observations show a general trend from S-tectonites dominant in the interior of the Mékinac-Taureau domain towards S-L and locally L-tectonites developed on its eastern boundary. The opposite variation, that is a transition from S-L-tectonites to S-tectonites, is observed from the boundary structurally up in the Shawinigan domain. As shown on Fig. 2, ESE-trending lineation is abundant and well clustered in the vicinity of the eastern TSZ (domain 3 on Fig. 2) whereas it is only rare and not clustered away from the TSZ. This clearly reveals the presence of the eastern TSZ, which separates the two domains.

The main shear zone is several hundred meters thick and is heterogeneously strained: rock from the TSZ is generally well-foliated and lineated, and locally shows well-developed mylonitic textures that may contain a pre-shearing relict foliation. In the latter case, the relict foliation $\left(S_{n}\right)$ is commonly crenulated and folded with axial planes parallel to the new foliation formed in the shear zone $\left(S_{n+1}\right.$, Fig. 3B). The stretching lineation associated with this shear fabric $\left(L_{n+1}\right)$ plunges gently $\left(10-35^{\circ}\right)$ towards the ESE (Fig. 2). Multiple shear-sense indicators such as $\sigma$-porphyroclast, $\delta$-porphyroclasts and asymmetric folds (Hanmer and Passchier, 1991) indicate a top-down-to-the-ESE tectonic displacement (Fig. 3C and D). Granitic pegmatites with pre- to syn-kinematic relationships are common in the TSZ. Information about the last increments of strain is provided by the relationship between the pegmatites and crosscutting marble layers of uncertain origin. These layers are of variable thickness $(5-200 \mathrm{~cm})$, present a high degree of qualitative strain, contain a foliation and a lineation parallel to those of the host gneiss, and contain clasts of host lithologic units, including pegmatites (Fig. 3A). At their margins, undeformed pegmatites become mylonitic and the entrainment of foliation of the host gneiss indicates a top-downto-the-ESE sense of shear (Fig. 3E). The marble layers thus accommodated the lasts strain increments of top-down-to-the-ESE sense of shear along the TSZ (Fig. 3E).

Kinematic indicators attesting to top-down-to-the-ESE sense of shear are also developed locally in 
NOTICE: this is the author's version of a work that was accepted for publication in Precambrian Research. Changes resulting from the publishing process, such as peer review, editing, corrections, structural formatting, and other quality control mechanisms may not be reflected in this document. Changes may have been made to this work since it was submitted for publication. A definitive version was subsequently published in Precambrian Research, 257, (Feb 2015). doi: 10.1016/j.precamres.2014.11.012

a metapelite layer of the Mékinac-Taureau domain three kilometers structurally below the eastern TSZ. At this locality, quartz ribbons are syn-kinematically recrystallized to form an oblique grain-shape fabric (Passchier and Trouw, 2005; Snoke et al., 1998) (Fig. 4A). This contrasts with the orthogneiss and structurally lower metapelites in which quartz forms fully annealed ribbons.

Finally, in the lower structural levels of the Shawinigan domain, there are multiple ductile-brittle extensional shear zones with a top-down-to-the-SE sense of shear (Fig. 4B). These shear zones probably accommodated only minor displacement because there is no metamorphic or lithological contrasts between the footwall and hanging wall. They may represent structurally higher equivalents of the eastern TSZ that were active during the waning stages of normal shearing.

\section{Thermobarometry}

\subsection{Qualitative interpretations}

Granulite-facies metapelite from both the Mékinac-Taureau and the Shawinigan domains have a similar mineral assemblage composed of Qtz $+\mathrm{Kfs}+\mathrm{Pl}+\mathrm{Grt}+\mathrm{Sil}+\mathrm{Bt} \pm \mathrm{Rt} \pm \mathrm{Ilm} \pm \mathrm{Zrn} \pm \mathrm{Mnz}$ (Fig. 5A). The presence of Kfs and the absence of Ms, Opx and Ky in the peak assemblage of metapelite constrain the conditions to temperatures higher than the Ms dehydration-melting reaction, below the Opx-in reaction and within the Sil stability field. In felsic to intermediate orthogneiss, the occurrence of migmatitic melt indicates conditions above the wet-solidus of granitic rocks.

There are several differences between the felsic to intermediate orthogneiss units of the Mékinac-Taureau and the Shawinigan domains. Based on our observations in the Mékinac-Taureau domain, the volume of leucosome in rock of felsic and intermediate composition increases structurally upward from only a few percent in the interior of the domain to $20-40 \%$ close to upper structural levels. Opx-bearing leucosome occurs in two structural settings. Pre- to syn-deformation leucosome is observed as stromatic layers parallel to the foliation and as pockets of leucosome trapped in boudin necks of more competent mafic layers or in hinges of isoclinal folds, whereas post-deformation leucosome is observed as undeformed, coarse patches that cross-cut the foliation. Because both types of leucosome contain the same mineralogy, and are locally intimately associated (i.e. stromatic leucosome merging into a cross-cutting pocket), our preferred interpretation is that migmatisation outlasted the deformation (e.g. Corrigan, 1995). Stromatic leucosome is also observed in the Shawinigan 
NOTICE: this is the author's version of a work that was accepted for publication in Precambrian Research. Changes resulting from the publishing process, such as peer review, editing, corrections, structural formatting, and other quality control mechanisms may not be reflected in this document. Changes may have been made to this work since it was submitted for publication. A definitive version was subsequently published in Precambrian Research, 257, (Feb 2015). doi: 10.1016/j.precamres.2014.11.012

domain, but to a lesser extent $(<20 \%)$. The most striking difference is the scarcity of orthopyroxene in Shawinigan domain intermediate orthogneiss (PI + Qtz $+\mathrm{Hbl}+\mathrm{Bt} \pm \mathrm{Kfs} \pm \mathrm{Cpx} \pm \mathrm{Opx}$ ) and, where present, orthopyroxene in this domain is typically partially retrogressed to hornblende. In the felsic to intermediate orthogneiss $(\mathrm{Pl}+\mathrm{Qtz}+\mathrm{Kfs}+\mathrm{Opx}+\mathrm{Bt}+\mathrm{Hbl})$ of the Mékinac-Taureau domain, on the other hand, orthopyroxene is abundant and unaltered, especially in the interior of the domain. The wider P-T stability field predicted for orthopyroxene in granodioritic orthogneiss compared to that predicted in metapelite by phase equilibria modeling (Gerya, 2004), most likely explain its presence and absence in the former and latter, respectively. Clinopyroxene is retrogressed to hornblende in intermediate orthogneiss of the Shawinigan domain and only locally in the upper levels of the Mékinac-Taureau domain. This suggests that retrograde metamorphic reactions affected the Shawinigan domain and, to a lesser extent, the Mékinac-Taureau domain. These qualitative observations suggest higher peak metamorphic in the Mékinac-Taureau domain as compared to the Shawinigan domain and/or a more profound retrograde metamorphism in the latter. As a clear metamorphic contrast in peak P-T conditions between the two domains cannot be demonstrated solely on the basis of petrographic observations, quantitative thermobarometry is required.

\subsection{Analytical methods and strategy}

Five metapelite samples and one amphibolite were selected along a transect of approximately ten kilometers of structural thickness to determine the overall metamorphic conditions characterizing the Mékinac-Taureau and Shawinigan domains. Metapelitic samples RS12-021, RS12-015A \& RS11-058, as well as RS11-105 \& RS12-027B were collected 5.5, 3 \& $2.5 \mathrm{~km}$ structurally below and 4 \& $6 \mathrm{~km}$ structurally above the TSZ, respectively. Amphibolite sample RS11-082B was collected within the shear zone (see Fig. 2 for locations). We considered that conventional thermobarometry was the best approach for our samples because: 1) the equilibrium volume chemical compositions to input in phase equilibria modeling would be difficult to estimate because of the heterogeneous texture of the rock; 2 ) the metapelitic samples do not show textures nor chemical zoning indicative of the retrograde nettransfer reactions that commonly precludes this type of P-T calculations in high-grade metapelite (cf. Spear and Florence, 1992; Spear et al., 1999); 3) amphibolite show textures and chemical zoning susceptible to yield information on the prograde and retrograde path.

Mineral compositions were determined using wavelength-dispersive spectrometry on a JXA JEOL- 
$8900 \mathrm{~L}$ microprobe at McGill University. Acceleration voltage was $15 \mathrm{kV}$, beam current was $20 \mathrm{nA}$, beam size was $5 \mu \mathrm{m}$ and counting time was 20 seconds. Natural mineral standards were used for calibrations and ZAF correction was used for data reduction. Additional details on standards used and detection limits for the different minerals under above conditions are provided in the supplementary data table 1. Pressure and temperature $(\mathrm{P}-\mathrm{T})$ values were calculated with the computer software TWEEQU (Thermobarometry With Estimation of EQUilibrium state) developed by Berman (1991). The TWEEQU version 2.3 (Berman, 2007) was used for calculations on metapelites because it is easier to calculate the classical thermobarometers involving garnet, biotite and plagioclase than with other software such as THERMOCALC, and because it uses a recent thermodynamic database (v2.32, Berman and Aranovich, in prep.) and solution models for garnet (Berman et al., 2007), biotite (Berman et al., 2007) and plagioclase (Fuhrman and Lindsley, 1988). Essene (1989) and Berman (1991) proposed uncertainties of $\pm 50{ }^{\circ} \mathrm{C}$ and $\pm 100 \mathrm{MPa}$ for P-T calculations using TWEEQU. For the amphibolite, we preferred to use the software THERMOCALC version 3.33 (Holland and Powell, 1998; Powell and Holland, 1988, 1994, 2008) with the thermodynamic dataset ds55 because it uses more recent solution models for amphiboles than TWEEQU (the Dale et al. (2005) model used with AX2 of Holland (2014) vs. the Mäder et al. (1994) model used with TWEEQU v. 1.02). We calculated relative P-T differences and associated uncertainties by calculating the standard deviations of $\mathrm{P}$ and $\mathrm{T}$ for all permutation of mineral compositions interpreted to have been in equilibrium by using the software TC_Comp (Dolivo-Dobrovolsky, 2013, http://www.dimadd.ru/en), as detailed below.

The following geothermometers and geobarometers were applied:

Metapelite

$$
\begin{aligned}
& A n n+\operatorname{Prp}=A l m+P h l \\
& A n=G r s+S i l+Q t z
\end{aligned}
$$

Amphibolite

$$
\begin{aligned}
& \text { Prp + Fac }=\text { Tr }+ \text { Alm } \\
& \text { Ts + Qtz + Grs + Alm = An + Prp + Fac } \\
& \text { Ts + Ab + Grs + Prp = An + Tr + Prg } \\
& \text { Grs + Prp + Qtz + Ts }=\text { Tr }+ \text { An }
\end{aligned}
$$

The proper evaluation of P-T conditions in high grade metapelite is a difficult task requiring many precautions (e.g. Spear and Florence, 1992). As several high temperature phenomena may modify the chemical composition of minerals, it is important to evaluate them to make sure that calculated P-T 
NOTICE: this is the author's version of a work that was accepted for publication in Precambrian Research. Changes resulting from the publishing process, such as peer review, editing, corrections, structural formatting, and other quality control mechanisms may not be reflected in this document. Changes may have been made to this work since it was submitted for publication. A definitive version was subsequently published in Precambrian Research, 257, (Feb 2015). doi: 10.1016/j.precamres.2014.11.012

points are significant. At high temperature $\left(>500-600^{\circ} \mathrm{C}\right)$, the growth zoning pattern of $\mathrm{Fe}, \mathrm{Mg}$, $\mathrm{Ca}$ and Mn in garnet is modified by intra-crystalline diffusion (e.g. Caddick et al., 2010; Tracy, 1982; Tracy et al., 1976; Yardley, 1977), which depends on the maximum temperature reached, the size of the crystal and the duration of metamorphism. For example, complete homogenization of a garnet with a diameter of 1 $\mathrm{mm}$ at temperature reaching $800^{\circ} \mathrm{C}$ would require tens of m.y., but the growth zoning pattern would be modified significantly within a few m.y. (Caddick et al., 2010). Inasmuch as the extent of diffusion depends on grain size, P-T calculations on garnet having different diameters should not yield similar values, unless they were completely re-equilibrated. On the other hand, Fe-Mg diffusion in biotite in contact with garnet is effective at $>525^{\circ} \mathrm{C}$ and at rates much faster than most metamorphic processes (Spear, 1993). Furthermore, Grt-Bt re-equilibration may occur during retrograde metamorphism via exchange reaction (1) and net transfer reaction:

$$
\text { Grt + Kfs + melt }=\mathrm{Bt}+\mathrm{Sil}+\mathrm{PI}+\mathrm{Qtz}(\text { Spear, 2004) }
$$

(Kohn and Spear, 2000; Spear, 1993, 2004; Spear and Parrish, 1996; Spear et al., 1999; Tracy, 1982). In addition, the net transfer reaction (7) produces plagioclase and biotite during melt crystallization that may not have compositions reflecting peak P-T conditions. Garnet involved in this reaction generally have embayments and invariably show a spike in $\mathrm{Mn}$ at their margins, whereas biotite produced by this reaction have a higher $\mathrm{Fe} /(\mathrm{Fe}+\mathrm{Mg})$ value than biotite that crystallized at peak conditions. Finally, the rate of Ca diffusion in plagioclase is much slower than the rate of most metamorphic processes; therefore plagioclase composition will only be modified by dissolution and reprecipitation (Grove et al., 1984). Minerals analyzed for peak P-T determination were therefore carefully selected to prevent the inaccuracies introduced by these high temperature phenomena on the calculated P-T points (e.g. Schaubs et al., 2002).

Petrographical observations (i.e. lack of muscovite and presence of sillimanite and K-feldspar in metapelite assemblage) suggest high peak temperature $\left(>650^{\circ} \mathrm{C}\right)$. Garnet chemical composition is thus expected to have partially to completely re-equilibrated during peak metamorphism and to possibly have been modified by post-peak metamorphic reactions. Largest available (500 to $4000 \mu \mathrm{m}$ ) garnets were selected because they are likely to preserve a chemical plateau in their cores that would be unaffected by retrograde reactions (Spear et al., 1999; Hauzenberger, 2005). In cases for which garnet did not show a perfectly flat zoning profile in its core, a plateau composition close to the rim was used in 
order to avoid the effect of relict growth zoning. Biotite isolated from garnet (e.g. trapped within a nonreacting phase such as quartz or feldspar), with high Ti content (suggestive of higher temperature; Henry et al., 2005), and that was parallel to the foliation (limiting the possibility of analyzing late biotite) was used rather than biotite in contact with garnet to minimize the effect of retrograde re-equilibration. Due to slow Ca diffusion rate in plagioclase, its composition reflects the conditions of crystallization or reprecipitation. Plagioclase was therefore selected from the groundmass in the vicinity of garnets (Holdaway, 2001), but away from any embayment in garnet (in rare cases where such embayments are present) to avoid plagioclase possibly formed by the retrograde net transfer reaction (7). Moreover, plagioclase rims were preferred over cores to avoid plagioclase that would have formed on the prograde path at lower temperatures than that corresponding with the re-equilibrated garnet core composition. Although great precautions were taken in the selection of minerals, it is difficult to ascertain that the calculated P-T truly represent the highest P-T conditions attained by the rocks. Results should therefore be considered minimum estimates of the peak P-T conditions.

The strategy adopted for the amphibolite sample RS011-082B is different and is described in detail along with the description of the textures to facilitate comprehension.

\subsection{Results}

A summary of the chemical compositions and the calculated P-T results is presented in table 1, garnet zoning profiles are presented on Fig. 6, and the complete chemical composition spreadsheets for the analyzed minerals is provided as supplementary data table 1 . The following section outlines the major compositional variations observed in the minerals and presents the thermobarometric results obtained from the three different domains.

\subsubsection{Interior of the Mékinac-Taureau domain in the footwall of the TSZ (RS12-021)}

Zoning profiles of euhedral garnet porphyroblasts are typically flat (Fig. 6A) and show little intercrystal variation. Biotite shows variation in chemical composition based on their relationship with garnet. Biotite in contact with garnet typically has low $\mathrm{Fe} /(\mathrm{Fe}+\mathrm{Mg})$ values compared to isolated biotite (0.31-0.33 vs. 0.36-0.39, respectively). Plagioclase is abundant and commonly has sharp, straight contacts with garnet. Its composition is relatively homogenous $\left(A n_{43}-A n_{46}\right)$. Calculated pressures and temperatures range from 1050 to $1120 \mathrm{MPa}$ and from 819 to $849^{\circ} \mathrm{C}$, respectively. 


\subsubsection{External zone of the Mékinac-Taureau domain near the TSZ (RS11-058 and RS12-015A)}

Garnet from these samples is not strongly resorbed and locally preserve pristine crystalline faces. Garnet zoning profiles of $\mathrm{Fe} /(\mathrm{Fe}+\mathrm{Mg})$ are generally flat or increases slightly from the core towards the rim, (maximum variation $(\Delta)<0.08$ ) (Fig. 6B-C). Garnet zoning profiles of $X_{\text {sps }}$ and $X_{\text {grs }}$ are flat throughout. Garnet show little inter-crystal variations, with the exception of rare smaller grains $(<1 \mathrm{~mm})$ that have abnormally high $\mathrm{Fe} /(\mathrm{Fe}+\mathrm{Mg})$ values that were thus excluded from calculations. Biotite in contact with garnet typically has low $\mathrm{Fe} /(\mathrm{Fe}+\mathrm{Mg})$ values compared to isolated biotite (0.36-0.37 vs. 0.40-0.44 and 0.26-0.34 vs. 0.36 vs 0.44 for samples RS11-058 and RS11-015A, respectively). Sample RS11-058 contains relatively homogeneous plagioclase $\left(A n_{37}-A n_{41}\right)$, but sample RS12-15A contains rare plagioclase (only five analyses) of variable composition $\left(\mathrm{An}_{8}-\mathrm{An}_{20}\right)$ that occurs as anhedral masses within or next to K-feldspar. In the latter sample, the large variation of composition, the small number of analyses, and the high probability that Ca-poor plagioclase is the result of exsolution or secondary precipitation prevented a confident selection of an appropriate plagioclase composition for geothermobarometric calculations. In sample RS11-058, calculated pressure ranges from 780 to $790 \mathrm{MPa}$ and temperature was determined at $780{ }^{\circ} \mathrm{C}$. Because of the lack of satisfactory plagioclase analyses in sample RS12-015A, no pressure determinations were attempted. However, a temperature range of $740-780^{\circ} \mathrm{C}$ was obtained, assuming a conservative pressure range of 600-1100 MPa.

\subsubsection{Shawinigan domain above the TSZ (RS12-027B and RS11-105)}

Garnet in sample RS12-27B is well preserved, whereas embayments filled with large unoriented biotite are locally present at the margins of garnet in sample RS11-105. Fe/(Fe+Mg) zoning profiles of all garnet from this domain are flat in the cores and increase in the rims $\left(<0.07\right.$, Fig. 6D-G). $X_{\text {grs }}$ profiles are typically flat, but a gradual decrease in $\mathrm{X}_{\text {grs }}(\Delta<0.02)$ may be observed towards the rim of some garnets. In sample RS12-027B, $\mathrm{X}_{\mathrm{sps}}$ is constant from core to rim, whereas systematic increases of $\mathrm{Mn}\left(<0.01 \mathrm{X}_{\mathrm{sps}}\right)$ are observed on garnet rims of sample RS11-105. Sample RS11-105 also contains three populations of garnet, occuring randomly in the thin section, that have similar composition profiles but different absolute concentrations of $\mathrm{Fe}, \mathrm{Mg}$ and $\mathrm{Ca}$. Their morphology is also different: type 1 is characterized by abundant ilmenite inclusions in the core with an inclusion-poor rim (Fig. 5C); type 2 is characterized by abundant quartz inclusions in the core and inclusion-poor rim (Fig. 5D); whereas type 3 consists of inclusion-poor garnet (Fig. 5E). 
NOTICE: this is the author's version of a work that was accepted for publication in Precambrian Research. Changes resulting from the publishing process, such as peer review, editing, corrections, structural formatting, and other quality control mechanisms may not be reflected in this document. Changes may have been made to this work since it was submitted for publication. A definitive version was subsequently published in Precambrian Research, 257, (Feb 2015). doi: 10.1016/j.precamres.2014.11.012

Biotite in contact with garnet has systematically lower Fe/(Fe+Mg) compared to armoured biotite (0.40-0.47 vs. 0.47-0.48 and 0.51-0.54 vs 0.53-0.56 for samples RS12-027B and RS11-105, respectively). In sample RS11-105, no systematic variation of the $\mathrm{Fe} /(\mathrm{Fe}+\mathrm{Mg})$ value in biotite with position was observed that could be related to the garnet type. Plagioclase is abundant in both samples and commonly found in stable contact with garnet. Its composition varies between $\mathrm{An}_{32}$ and $A n_{38}$ in sample RS12-027B whereas sample RS11-105 contains homogeneous plagioclase $\left(\mathrm{An}_{21}-\mathrm{An} \mathrm{n}_{22}\right)$. Ca-poor plagioclase $\left(\mathrm{An}_{2}\right.$ to $\left.A n_{15}\right)$ in sample RS12-027B, occurring as patches in K-feldspar and interpreted as the result of exsolution or secondary precipitation, was not used for thermobarometric calculations.

Sample RS12-27B yielded pressures and temperature of 740-790 MPa and $780{ }^{\circ} \mathrm{C}$. In sample RS11105 , calculated pressures and temperatures for type 1 garnet range from 720 to $860 \mathrm{MPa}$ and from 730 to $750{ }^{\circ} \mathrm{C}$, respectively, whereas both types 2 and 3 garnets registered lower P-T conditions of 620-650 $\mathrm{MPa}$ and $700-710^{\circ} \mathrm{C}$.

\subsubsection{Eastern TSZ (RS11-082B)}

This amphibolite contains sigmoid-shaped coronas of plagioclase and minor hornblende surrounding garnet (Fig. 5F), in a groundmass of $\mathrm{Hbl}+\mathrm{Pl}+\mathrm{Qtz}+\mathrm{Mag}+\mathrm{Ilm}+\mathrm{Ttn}$. It also shows plagioclase-rich patches similar in size to garnet crystals and surrounded by the same groundmass, that are interpreted as garnet pseudomorphs formed from the retrograde decompression reaction:

$$
\text { Tschermakite-Hbl + Grt + Qtz = Tremolitic-Hbl + PI (Schaubs et al., 2002) }
$$

The sigmoidal shape of the reaction rims suggests that they are pre- to syn-kinematic with respect to top-down-to-the-ESE movement. Retrograde conditions obtained with this sample therefore provides P-T constraints corresponding to shearing along the eastern TSZ.

The chemical compositions of minerals in this sample supports this interpretation because they systematically vary according to their textural locations. $\mathrm{Fe} /(\mathrm{Fe}+\mathrm{Mg})$ and $\mathrm{X}_{\text {sps }}$ profiles in garnet are either flat or progressively decreases from core to inner $\operatorname{rim}(\Delta<0.05$ and 0.04 , respectively; Fig. $6 \mathrm{H})$. The largest garnet grains present evidence of a prograde P-T path (Fig. 6H) with a gradual increase in $\mathrm{X}_{\text {grs }}$ from core to inner $\operatorname{rim}(\Delta<0.09)$ followed by decompression evidenced by a sharp decrease in $\mathrm{X}_{\mathrm{grs}}$ towards the outer $\operatorname{rim}(\Delta<0.13)$. Two populations of hornblende are recognized. The first occurs as large $(1000-3000 \mu \mathrm{m})$ crystals in in the groundmass and is characterized by higher Fe/(Fe+Mg) values (0.43- 
0.45) compared to the second population composed of small $(100-400 \mu m)$ in the coronas surrounding the garnet $(\mathrm{Fe} /(\mathrm{Fe}+\mathrm{Mg})=0.40-0.44)$. Plagioclase from the groundmass yield values of $A n_{40}$ to $A n_{51}$ that are clearly distinctive from that in the coronas, which yield values of $A n_{49}$ to $A n_{58}$. These patterns suggest that thermobarometry could provide good estimate on peak and retrograde conditions.

Our interpretation that the disequilibrium coronitic texture linked with chemical variation in minerals provide information about the peak and retrograde history of the rock requires two conditions. First, parts of garnet, plagioclase and hornblende must have been in chemical equilibrium at the scale of the thin-section when the rock was at peak and at the end of the retrograde path. Second, chemical compositions that prevailed at the peak were preserved in parts of several minerals despite subsequent diffusion and recrystallization that took place afterward. If these two conditions are met in our sample, then every P-T calculated from any garnet-plagioclase-hornblende compositions interpreted to have been in equilibrium at peak or at the end of the retrograde path should yield the same values within analytical and reasonable geological errors. We tested this by using the software TC_Comb (DolivoDobrovolsky, 2013, http://www.dimadd.ru/en) that allows rapid P-T calculations by the average PT method (Holland and Powell, 1994) for all possible permutations of a set of mineral compositions. As a set interpreted to reflect peak mineral compositions, we selected 17 analyses from the core of four garnet grains showing minimal evidence of diffusion (i.e. flat for at least two succesive points), the six hornblende analyses located in the matrix, and the four plagioclase analyses located in the groundmass near the selected garnet grains. Calculations of P-T for all permutations of these analyses resulted in a well clustered cloud of correlated points yielding mean temperature and pressure of $880 \pm 80^{\circ} \mathrm{C}$ and 990 $\pm 120 \mathrm{MPa}$, respectively. To calculate retrograde conditions, we selected five analyses from the rim of five garnet grains surrounded by a plagioclase + hornblende coronae, as well as six hornblende and 22 plagioclase grains located in these coronas. Calculations of P-T for all permutations of these analyses resulted in a well clustered cloud of correlated points yielding mean temperature and pressure of $720 \pm$ $30^{\circ} \mathrm{C}$ and $650 \pm 50 \mathrm{MPa}$, respectively. The uncertainties are $2 \sigma$ and do not reflect uncertainties associated with the mineral database. The difference between these mean values are highly significant $(\mathrm{p}<0.0001)$ yielding $162^{\circ} \mathrm{C}$ with a $95 \%$ confidence interval of $157-166^{\circ} \mathrm{C}$ and $340 \mathrm{MPa}$ with a $95 \%$ confidence interval of 330-350 MPa. These results clearly demonstrate that minerals in amphibolite sample RS11-082B reached chemical equilibrium at peak and at the end of the retrograde path and that the two P-T conditions are clearly distinct. 


\subsection{Interpretation of thermobarometry results}

The chemical compositions of analyzed garnet and biotite reveal important information about the metamorphic history of the metapelites from the Mauricie area. First, completely flat $\mathrm{Fe} /(\mathrm{Fe}+\mathrm{Mg}), \mathrm{X}_{\mathrm{grs}}$ and $\mathrm{X}_{\mathrm{sps}}$ zoning profiles of most garnets from the interior of the Mékinac-Taureau domain suggest complete intra-crystalline diffusion of $\mathrm{Fe}, \mathrm{Mg}, \mathrm{Ca}$ and $\mathrm{Mn}$ in garnet during peak metamorphism. Since biotite in contact with garnet has a lower $\mathrm{Fe} /(\mathrm{Fe}+\mathrm{Mg})$ value compared to armoured biotite, the exchange reaction (1) probably occurred during retrograde metamorphism, but the expected opposite pattern is not present in adjacent garnet, probably because the transects were located away from zones of contact with biotite. Most importantly, garnet in sample RS11-021 is euhedral (Fig. 5B) and does not show a variation in $\mathrm{X}_{\mathrm{sps}}$, which suggests that it did not start to break down via the retrograde net transfer reaction (7).

Pressure and temperature calculated with compositional plateaus in garnet core, armoured biotite and matrix plagioclase are therefore interpreted as the metamorphic peak conditions of the Mékinac-Taureau domain. The calculated conditions of $\sim 1075 \mathrm{MPa}$ and $\sim 825{ }^{\circ} \mathrm{C}$ lie in the kyanite stability-field and could suggest underestimation of the temperature, but they are nonetheless within error of the sillimanite stability-field, and hence in agreement with petrographic observations considering uncertainties. The temperature measured in this study is in agreement with previous results of $\geq 800{ }^{\circ} \mathrm{C}$ by (Corrigan, 1995; Herd et al., 1986). However, the pressure estimate of $1075 \mathrm{MPa}$ is above the previous results of 800-900 MPa (Corrigan, 1995; Herd et al., 1986).

In the external zone of the Mékinac-Taureau domain, garnet cores in metapelite have essentially flat zoning profiles in $\mathrm{Fe} /(\mathrm{Fe}+\mathrm{Mg}), \mathrm{X}_{\mathrm{grs}}$ and $\mathrm{X}_{\mathrm{sps}}$, suggesting complete intra-crystalline diffusion of $\mathrm{Fe}, \mathrm{Mg}$, $\mathrm{Ca}$ and $\mathrm{Mn}$ in garnet during peak metamorphism. However, garnet crystals show a slight increase in $\mathrm{Fe} /(\mathrm{Fe}+\mathrm{Mg})$ toward their rims $(\Delta<0.08)$. This is the result of limited diffusion by the retrograde exchange reaction (1). The systematic decrease in $\mathrm{Fe} /(\mathrm{Fe}+\mathrm{Mg})$ value of biotite in contact with garnet, as compared with armoured biotite, supports such an interpretation. The lack of $X_{\text {sps }}$ increase at the rim suggests that the garnet consuming net transfer reaction (7) did not operate. The pressure of $790 \mathrm{MPa}$ and temperature of $\sim 775{ }^{\circ} \mathrm{C}$ calculated with compositional plateaus from the garnet core, armoured biotite and matrix plagioclase are therefore interpreted as the prevailing conditions during high grade Grt-Bt reequilibration in the external zone of the Mékinac-Taureau domain. Furthermore, Grt and Bt were only 
affected to a limited degree by the retrograde exchange reaction (1) and chemical compositions used for calculations were selected to avoid the effects of this reaction. A metamorphic temperature estimate of $\sim 770{ }^{\circ} \mathrm{C}$ in the southeastern margin of the Mékinac-Taureau domain has been previously provided by Lévesque (1995), which is consistent with data presented above. In any case, these results are lower than metamorphic peak conditions obtained for the interior of the Mékinac-Taureau domain.

The amphibolite RS11-082B collected at the eastern TSZ indicates that similar P-T conditions of $\sim 990 \mathrm{MPa}$ and $\sim 880^{\circ} \mathrm{C}$ prevailed during the metamorphic peak throughout the Mékinac-Taureau domain. As shown on Fig. 7, peak and retrograde P-T values are equivalent to those yielded by the metapelites from the interior and the margin of the Mékinac-Taureau domain. The statistical analysis further demonstrates that the difference between the mean peak and retrograde P-T conditions are significant. Moreover, the reaction rims around garnet in the amphibolite were deformed during topdown-to-the-ESE shearing along the eastern TSZ and must have formed prior to or during that shearing. This implies that the eastern TSZ was formed under P-T conditions $\leq 600-700 \mathrm{MPa}$ and $\leq 675-775{ }^{\circ} \mathrm{C}$, respectively.

In the Shawinigan domain, garnet cores in metapelite have essentially flat zoning profiles $\mathrm{Fe} /(\mathrm{Fe}+\mathrm{Mg}), \mathrm{X}_{\mathrm{grs}}$ and $\mathrm{X}_{\mathrm{sps}}$, suggesting complete intra-crystalline diffusion of $\mathrm{Fe}, \mathrm{Mg}, \mathrm{Ca}$ and $\mathrm{Mn}$ in garnet during peak metamorphism. However, garnet crystals show a slight increase Fe/(Fe+Mg) toward their rims $(\Delta<0.07)$. Sample RS11-105 contains garnet that has a small $X_{\text {sps }}$ increase at the rim $(\Delta<0.02)$, which probably resulted from net transfer reaction (7). Such reactions theoretically increase the $\mathrm{Fe} /(\mathrm{Fe}+\mathrm{Mg})$ value of biotite in contact with garnet, but in our sample, $\mathrm{Fe} /(\mathrm{Fe}+\mathrm{Mg})$ values are lower in biotite in contact with garnet as compared to armoured biotite. This suggests that the effect of net transfer reaction (7) was overwhelmed by the effect of exchange reaction (1), which decreases the $\mathrm{Fe} /(\mathrm{Fe}+\mathrm{Mg}$ ) value of biotite. Although the retrograde exchange and net transfer reactions (1) and (7) affected the composition of the rim of garnet, the large compositional plateau in the core indicates a complete Grt-Bt re-equilibration at high temperature. P-T values yielded by this sample are dispersed along an array (Fig. 7) with types 2-3 garnets lying on the lower grade side and type 1 garnet on the higher grade side. This may suggest two episodes of garnet growth. Chemical plateaus in type 1 garnets imply complete intracrystalline diffusion at higher grade than conditions recorded by types $2-3$. Considering that type 2 garnets are equivalent in size to type 1 and that type 3 garnets are approximately half the size of type 1 
garnet, prograde conditions cannot be preserved in types 2-3 garnets. An alternative hypothesis would be that types 2-3 garnets grew during decompression and cooling, but this would require an unexplained thermal spike during the retrograde path. Molar isopleths of garnet in metapelites (e.g. Storm and Spear, 2005) have steep slopes on P-T diagrams for the considered P-T conditions (i.e. 625$650 \mathrm{MPa}$ and $700{ }^{\circ} \mathrm{C}$ ). Therefore, temperature must increase to produce new garnet. It may also be possible that abundant ilmenite inclusions in type 1 garnet induce a $\mathrm{Fe} /(\mathrm{Fe}+\mathrm{Mg})$ decrease in garnet that results in over-estimation of metamorphic conditions. Pressure and temperature calculated with compositional plateaus from garnet core of samples RS12-027B and RS11-115 along with and armoured biotite and matrix plagioclase are interpreted as the metamorphic peak conditions of the Shawinigan domain at $\sim 625-850 \mathrm{MPa}$ and $\sim 700-775^{\circ} \mathrm{C}$. Such metamorphic conditions are consistent, within error, with data from Lévesque (1995) $\left(725-800{ }^{\circ} \mathrm{C}\right.$ at $\left.720-880 \mathrm{MPa}\right)$.

In summary, the necessary precautions in the selection of minerals were taken and we carefully interpreted the results to provide meaningful P-T values for high grade rocks. The non-existent to limited effects of the retrograde net transfer reaction (7), allowed the preservation of large chemical plateaus in the cores of garnets. Peak metamorphism in the Mékinac-Taureau domain attained P-T conditions of $1000-1100 \mathrm{MPa}$ and $820-880^{\circ} \mathrm{C}$, whereas retrograde conditions varying from 800 to 650 MPa and from 775 to $675{ }^{\circ} \mathrm{C}$ were recorded in its upper structural levels. The Shawinigan domain records P-T conditions varying from 850 to $625 \mathrm{MPa}$ and from 775 to $700{ }^{\circ} \mathrm{C}$. The decreasing P-T trend from the Mékinac-Taureau domain to the Shawinigan domain described in this study is therefore significant.

\section{U-Pb geochronology}

\subsection{Pegmatite samples description and setting}

\subsubsection{Sample RS11-098}

In order to constrain the timing of deformation along the eastern TSZ, a pegmatite intrusion synchronous with normal shearing (RS11-098) was sampled at the St-Tite gravel pit (Fig. 8A). This pegmatite has a granitic composition ( $\mathrm{Qtz}+\mathrm{Kfs}+\mathrm{PI}+\mathrm{Bt}+\mathrm{Chl}$ (late) $+\mathrm{Zrn}+\mathrm{Mnz}$ ) and forms a 3-m wide body, from which the analyzed sample was collected, surrounded by abundant dykelets, extending away from it. The pegmatite cross-cuts the $S_{n+1}$ foliation in the host gneiss $\left(S_{n+1} \approx 330 / 32\right)$, but locally shows a weakly-developed internal foliation parallel to $S_{n+1}$. Contacts with the host gneiss are sharp and the 
NOTICE: this is the author's version of a work that was accepted for publication in Precambrian Research. Changes resulting from the publishing process, such as peer review, editing, corrections, structural formatting, and other quality control mechanisms may not be reflected in this document. Changes may have been made to this work since it was submitted for publication. A definitive version was subsequently published in Precambrian Research, 257, (Feb 2015). doi: 10.1016/j.precamres.2014.11.012

composition of the pegmatite is homogeneous, suggesting they are dilation dykes (in the sense of Goodspeed, 1940). Above the main body of pegmatite, a series of foliated dykelets is clearly transposed parallel to $S_{n+1}$ whereas the foliation in the hosting gneiss forms S-shaped planes. Planar fabrics defined by both the pegmatite dykelets and the host rock foliation are interpreted as similar to a C-S structure indicating top-down-to-the-ESE shearing (Fig. 8B). The transposition of S planes during shearing was probably interrupted by the emplacement of the dykelets, which then accommodated further strain. To the right end of the pegmatite body, a $20 \mathrm{~cm}$-thick dyke dips ESE and cuts across $\mathrm{S}_{n+1}$ at an angle of $\sim 40^{\circ}$. Inasmuch as this orientation is perpendicular to the minimum shortening direction under top-down-tothe-ESE shearing, this dyke, which resemble extensional fault-propagation fold and associated dilation dike (Schwerdtner et al. 2014), is interpreted to have been emplaced in a fracture conjugate to the shear plane (e.g. Davidson et al., 1994). At the margins of that dyke, $S_{n+1}$ is dragged downward on the NW side and upward on the SE side, which is also consistent with top-down-to-the-ESE (Fig. 8A). We therefore consider that the isotopic dating of pegmatite crystallization provides an age constraint for the normalsense shearing deformation observed on the eastern TSZ.

\subsubsection{Sample RS12-040}

Another granitic pegmatite (RS12-040) was sampled at an outcrop located approximately $2 \mathrm{~km}$ structurally below the eastern TSZ. This outcrop is composed of strongly migmatised and folded, felsic to mafic orthogneiss. Leucosome material contains orthopyroxene and is commonly trapped within the hinges of recumbent folds of undetermined vergence, indicating that partial melting was mostly contemporaneous with peak metamorphism and deformation. Moreover, some pockets of leucosome locally cut across the foliation, suggesting that partial melting outlasted deformation and possibly occurred after metamorphic peak. Because this outcrop does not show evidence of shearing typical of the eastern TSZ, deformation there is attributed to the older event associated with the development of foliation $\mathrm{S}_{\mathrm{n}}$. The sampled pegmatite is made up of $\mathrm{Qtz}+\mathrm{Kfs}$ (perthitic) $+\mathrm{Pl}+\mathrm{Bt}+\mathrm{Chl}$ (late) $+\mathrm{Zr}+\mathrm{Mnz}$ and opx-bearing leucosome in the host gneiss commonly merges into the pegmatite without clear crosscutting relationships. Contact between the pegmatite dyke and the host gneiss melanosome is sharp and rectiplanar, suggesting that the pegmatite dyke is a dilation dyke (Goodspeed, 1940). Its crystallization age therefore provides a minimum age for the deformational episode related to crustal thickening and associated peak metamorphism. 


\subsection{Analytical methods}

Zircon grains were separated from rocks using standard techniques. Zircon was mounted in epoxy, polished until the centers of the grains were exposed, and imaged with cathodoluminescence (CL). Zircon was analyzed by Laser Ablation Inductively Coupled Plasma Mass Spectrometry (LA-ICPMS) using a ThermoElectron X-Series II quadrupole ICPMS and New Wave Research UP-213 Nd:YAG UV (213 nm) laser ablation system at Boise State Univeristy (Idaho, USA). In-house analytical protocols, standard materials, and data reduction software were used for acquisition and calibration of U-Pb dates and a series of selected high field strength (HFSE) and rare earth elements (REE). Zircon grains were ablated with a laser spot of 25 and $30 \mu \mathrm{m}$ wide. Additional details concerning analytical methods are available in the supplementary data repository.

For groups of analyses that were collectively interpreted as a weighted mean date (i.e., igneous zircon analyses), a weighted mean date was first calculated with Isoplot 3.0 (Ludwig, 2003) using errors on individual dates that do not include a standard calibration uncertainty, and then a standard calibration uncertainty was propagated into the error on the weighted mean date. Age interpretations are based on weighted mean ${ }^{207} \mathrm{~Pb} /{ }^{206} \mathrm{~Pb}$ dates, which are more precise than $\mathrm{U} / \mathrm{Pb}$ dates upon propagation of the standard calibration uncertainties and not affected by recent $\mathrm{Pb}$ loss. Analyses that are $>15 \%$ discordant are interpreted as being from domains that lost $\mathrm{Pb}$ and were not considered. $\mathrm{A}$ few analyses with $<15 \%$ discordance were not included in the weighted mean calculations because they are not equivalent with the other dates, most likely due to small amounts of $\mathrm{Pb}$ loss $\left({ }^{206} \mathrm{~Pb} /{ }^{238} \mathrm{U}\right.$ dates $)$ or common $\mathrm{Pb}\left({ }^{207} \mathrm{~Pb} /{ }^{206} \mathrm{~Pb}\right.$ dates). Errors on the ${ }^{207} \mathrm{~Pb} /{ }^{206} \mathrm{~Pb}$ and ${ }^{206} \mathrm{~Pb} /{ }^{238} \mathrm{U}$ dates from individual analyses are given at $2 \sigma$, as are the errors on the weighted mean dates.

\subsection{Results}

\subsubsection{Pegmatite sample RS11-098}

Zircon was classified into four compositional groups according to trace element concentrations. Some differences are also apparent in their morphology and zoning patterns in cathodoluminescence (CL) images (Fig. 9A). Trace element contents are presented below in the following format: (min-max values; average value). Complete chemical composition data and Concordia diagrams are presented in supplementary data table 2 and Fig. S1. 
NOTICE: this is the author's version of a work that was accepted for publication in Precambrian Research. Changes resulting from the publishing process, such as peer review, editing, corrections, structural formatting, and other quality control mechanisms may not be reflected in this document. Changes may have been made to this work since it was submitted for publication. A definitive version was subsequently published in Precambrian Research, 257, (Feb 2015). doi: 10.1016/j.precamres.2014.11.012

Group 1 zircon is composed of homogeneous to oscillatory-zoned, CL dark, subequant grains (Fig 9A), characterized by high $U$ and Th contents (210-420; 306 and 110-330; 201 ppm; Fig 10A) and low Th/U values (0.5-0.8; 0.7). It has medium Y (480-1300; 829 ppm), Nb (4-8; 5 ppm), Hf (9940-11530; 10783 ppm), middle rare earth elements (MREE: Sm-Gd) and heavy rare earth elements (HREE: Tb-Lu) contents.

Group 2 zircon is composed of $\mathrm{CL}$ paler grains that are frequently sector or patchy zoned. It commonly forms individual grains and/or secondary rims of overgrowth on Group 1 (Fig 9A). It is characterized by low to medium U content (80-210; 133 ppm; Fig 10A), low Th content (60-190; 101 ppm; Fig 10A) and low Th/U value similar to group 1 (0.5-0.9; 0.8). It has relatively low Y (360-970; 591 ppm), Nb (2-5; 3 ppm), MREE, HREE contents and relatively high Hf content (9200-13410; 10968 ppm).

Group 3 zircon is composed of CL pale oscillatory and patchy zoned zircon. It usually forms individual grains, but one occurrence shows Group 3 zircon rim overgrowing a Group 1 zircon core (Fig 9A). Group 3 is characterized by low U content, (50-130; 103 ppm; Fig 10A), medium Th content (70-210; 157 ppm; Fig 10A) and relatively high Th/U value (1.1-1.8; 1.5). It has relatively high Y (750-1450; 1198 ppm), Nb (2-7; 6 ppm), MREE and HREE contents and relatively low Hf content (7820-10930; 9407 ppm).

Group 4 zircon is composed of homogeneous to patchy zoned CL dark cores (Fig 9A). It has low to very high $U$ and Th content (100-650; 387 and 90-510; 300; Fig 10A) and medium Th/U values (0.5-1.0; 0.8). It has relatively high Y (940-1920; 1491 ppm) and Nb (1-9; 6 ppm) contents, very high MREE (SmGd) and HREE (Tb-Lu) contents and relatively low Hf content (7210-11780; 9855 ppm).

Differences and similarities in the chemical composition of Groups 1-4 are well illustrated by a series of selected compositional variation diagrams (Fig. 10). The distinction between zircon groups is particularly obvious in the Th vs. $U$ diagram (Fig. 10A), in which each group shows a distinctive compositional trend that reflects variations in the Th/U value. Other diagrams such as $\mathrm{Lu} / \mathrm{Hf}$ vs. Th/Y, and Th/Y vs. Y/Hf (Fig. 10B-C) also show clear differences between the four groups. Groups 1 and 2 typically have overlapping chemical compositions, whereas Group 3 is clearly distinguishable, as shown by the $\mathrm{Nb} / \mathrm{U}$ vs. Th/U diagram (Fig. 10D). Group 4 comprises zircon cores of various chemical compositions that generally lie off the chemical compositional field of Groups 1-3 in some diagrams.

The temperature of crystallization of the analyzed zircon grains was calculated based on the Ti-in- 
zircon thermometer, developed by Watson et al. (2006), using the more recent calibration of Ferry and Watson (2007) and the pressure dependence of Ferriss et al. (2008). For Groups 1-3, $\mathrm{aTiO}_{2}=0.8$ and $\mathrm{P}=700 \mathrm{MPa}$ were used to correct the temperature calculations, whereas the same $\mathrm{aTiO}_{2}$ without any pressure correction (i.e. $\mathrm{P}=1000 \mathrm{MPa}$ ) were used for Group 4. All temperatures of crystallization are subject to an uncertainty of $\pm 30{ }^{\circ} \mathrm{C}$ comprising uncertainties on the Ti content measurement, on the calibration error of the thermometer equation, on the estimated value of $\mathrm{aTiO}_{2}$ and on the estimated pressure during crystallization, all added in quadrature. Additional details on the calculation of the uncertainty and the choice of correction factors are available in the supplementary data repository. The average temperature of crystallization of Group 1 is $691{ }^{\circ} \mathrm{C}$; Group 2 is $703{ }^{\circ} \mathrm{C}$ and Group 3 is $707^{\circ} \mathrm{C}$. Group 4 zircon crystallized at temperature varying from 716 to $794^{\circ} \mathrm{C}$.

All interpretations are based on ${ }^{207} \mathrm{~Pb} /{ }^{206} \mathrm{~Pb}$ dates (Fig. 11A-C) because they are more precise upon propagation of calibration errors and not affected by recent $\mathrm{Pb}$ loss. ${ }^{206} \mathrm{~Pb} /{ }^{238} \mathrm{U}$ dates are nonetheless presented here for comparison purposes, but were not used in interpretations. Weighted mean ${ }^{207} \mathrm{~Pb} /{ }^{206} \mathrm{~Pb}$ and ${ }^{206} \mathrm{~Pb} /{ }^{238} \mathrm{U}$ dates obtained from Groups 1-3 are equivalent whereas they are older in Group 4. Group 1 yielded a ${ }^{207} \mathrm{~Pb} /{ }^{206} \mathrm{~Pb}$ date of $1064 \pm 15 \mathrm{Ma}$ (mean square weighted deviation $(M S W D)=1.3$, probability of fit $(P F)=0.16$, number of analyses $(n)=22)$ and a ${ }^{206} \mathrm{~Pb} /{ }^{238} \mathrm{U}$ date of $1058 \pm 27$ Ma (MSWD=1.1, $P F=0.32, n=21$ ). Group 2 yielded a ${ }^{207} \mathrm{~Pb} /{ }^{206} \mathrm{~Pb}$ date of $1058 \pm 16 \mathrm{Ma}(\mathrm{MSWD}=1.1$, $\mathrm{PF}=0.34, \mathrm{n}=28)$ and $\mathrm{a}^{206} \mathrm{~Pb} /{ }^{238} \mathrm{U}$ date of $1042 \pm 26 \mathrm{Ma}(\mathrm{MSWD}=0.9, \mathrm{PF}=0.55, \mathrm{n}=25)$. Group 3 yielded a ${ }^{207} \mathrm{~Pb} /{ }^{206} \mathrm{~Pb}$ date of $1063 \pm 17 \mathrm{Ma}(\mathrm{MSWD}=1.4, \mathrm{PF}=0.08, \mathrm{n}=31)$ and $\mathrm{a}{ }^{206} \mathrm{~Pb} /{ }^{238} \mathrm{U}$ date of $1047 \pm 26 \mathrm{Ma}$ (MSWD=1.0, $\mathrm{PF}=0.41, \mathrm{n}=34$ ). Group 4 yielded ${ }^{207} \mathrm{~Pb} /{ }^{206} \mathrm{~Pb}$ dates of $1459 \pm 50$ to $1052 \pm 53 \mathrm{Ma}$ and ${ }^{206} \mathrm{~Pb} /{ }^{238} \mathrm{U}$ dates of $1421 \pm 60$ to $1032 \pm 58 \mathrm{Ma}$.

\subsubsection{Pegmatite sample RS12-040}

The chemical composition, morphology, zoning patterns in $\mathrm{CL}$ images and age of zircon from sample RS12-040 do not define distinct groups. These analyses are consequently treated as a unique group. Dark xenocrystic cores were easily distinguished and avoided during analysis. Trace element contents are presented in the following format: (min-max values; average value) and the complete chemical composition data and Concordia diagram are presented in supplementary data table 2 and Fig. S1. Zircon grains are generally prismatic and have an aspect ratio varying from 1:1 to 1:5. They are commonly oscillatory zoned and dark in CL (Fig. 9B). They are characterized by medium to high $\mathrm{U}$ and Th 

process, such as peer review, editing, corrections, structural formatting, and other quality control mechanisms may not be reflected in this document. Changes may have been made to this work since it was submitted for publication. A definitive version was subsequently published in Precambrian Research, 257, (Feb 2015). doi: 10.1016/j.precamres.2014.11.012

contents (90-340; 166 and 40-570; 252) and high Th/U values (0.1-2.9; 1.52). They have high $\mathrm{Y}$ and $\mathrm{Nb}$ content (540-2790; 1148 and 3-8; 6), variable Hf content (8230-15060; 10362), medium MREE and relatively high HREE (Tb-Lu) contents. Their temperature of crystallization has been estimated at $755 \pm$ $30{ }^{\circ} \mathrm{C}$ with $\mathrm{aTiO}_{2}=0.8$ and $\mathrm{P}=1000 \mathrm{MPa}$.

Weighted mean ${ }^{207} \mathrm{~Pb} /{ }^{206} \mathrm{~Pb}$ and ${ }^{206} \mathrm{~Pb} /{ }^{238} \mathrm{U}$ dates from sample RS12-040 are equivalent. It yielded $\mathrm{a}{ }^{207} \mathrm{~Pb} /{ }^{206} \mathrm{~Pb}$ date of $1082 \pm 20 \mathrm{Ma}$ (Fig. 11D; MSWD=1.4, PF =0.06, $\mathrm{n}=35$ ) and $\mathrm{a}^{206} \mathrm{~Pb} /{ }^{238} \mathrm{U}$ date of 1055 $\pm 34 \mathrm{Ma}(\mathrm{MSWD}=1.3, \mathrm{PF}=0.11, \mathrm{n}=39$ ).

\subsection{Interpretation of zircon chemical composition and U-Pb dates}

Relatively large errors on U-Pb dates yielded by the LA-ICP-MS method preclude a clear distinction between Groups 1-3 zircons of the pegmatite sample RS11-098. More precise TIMS dating is needed to precisely determine age differences, if any. However, petrographical relationships suggest that Group 1 zircon grains are the oldest since they are commonly overgrown by Group 2 and rarely by Group 3 (Fig. 9A). Given their homogeneous chemical composition and the lack of sector zoning or zonation perturbation, Group 1 zircon grains are interpreted as primary igneous zircons that formed during the crystallization of the pegmatite. The great compositional similarity between Groups 1 and 2 zircons suggests that Group 2 formed by recrystallization and/or dissolution and re-precipitation of Group 1. Such an interpretation is supported by the constant depletion in non-essential structural constituent cations such as $\mathrm{U}, \mathrm{Th}, \mathrm{Y}, \mathrm{Nb}$ and $\mathrm{REE}$, which are commonly removed in fluid-altered zircon, of Group 2 as compared to Group 1 (Hoskin and Black, 2000; Hoskin and Schaltegger, 2003). Furthermore, the small enrichment in $\mathrm{Hf}$ content of Group 2 zircon compared to Group 1 is also characteristic of recrystallization of a pre-existing zircon population (Pan, 1997). Finally, the patchy and sector zonation common in Group 2 is considered as typical of metamorphic zircon or igneous zircon perturbed by latemagmatic processes (Corfu et al., 2003).

Group 3 zircon has a distinct chemical composition, suggesting that it possibly originated from a distinct fluid phase. Rare overgrowing of Group 1 zircon grains indicates that Group 3 zircon is younger, but no physical relationship were observed between Groups 2 and 3 (Fig. 9A). Group 3 zircon comprises mostly patchy zoned crystals that probably grew in solid state, but minor oscillatory zoned zircon grains suggest that some may have grown in the presence of a fluid phase. Group 3 zircon is therefore interpreted as metamorphic, but derived from a different source than that of Group 2. Scarcity of Group 
3 zircon overgrowing Groups 1-2 zircons would be explained if Group 3 zircon only formed in discrete domains related to fluid infiltration following the crystallization of the pegmatite. However, further insitu work on new samples is needed to test this hypothesis since the crushing process destroyed evidence of any such domains, if present.

Group 4 is composed of zircon cores of various chemical compositions that do not fit with Group 1-3 chemical composition. Group 4 also typically yields older U-Pb dates and is therefore interpreted as being xenocrystic (inherited).

Temperatures of crystallization of Groups $1-3\left(691{ }^{\circ} \mathrm{C}\right.$, $703{ }^{\circ} \mathrm{C}$ and $707{ }^{\circ} \mathrm{C}$, respectively) are equivalent within the $\pm 30^{\circ} \mathrm{C}$ uncertainty. Since the pegmatite was emplaced during the exhumation of the hosting units, it would be expected to see a temperature decrease from the oldest to the youngest group of zircons. However, such a decrease is not resolvable with the present data. $\mathrm{A} 14{ }^{\circ} \mathrm{C}$ increase is even observed from group 1 to group 3. A pressure decrease between Group 1 and Group 3 crystallization would elegantly explain this apparent increase in temperature, because pressure decrease leads to overestimation of the temperature calculated with the Ti-in-zircon thermometer (Ferris et al., 2008; Ferry and Watson, 2007). However, the large uncertainties on many other parameters (especially $\mathrm{aTiO}_{2}$ ) impede confident interpretation of temperature variations between zircon groups from sample RS11-098. Nonetheless, temperatures calculated for the crystallization of Groups 13 zircons $\left(691-707 \pm 30^{\circ} \mathrm{C}\right.$ ) are equivalent, within error, to temperatures of retrograde metamorphism registered by the amphibolite and the metapelites of the upper structural levels of the Mékinac-Taureau domain (675-775 $\pm 50^{\circ} \mathrm{C}$; section 5.3). Temperatures of zircon crystallization thus support the emplacement of the pegmatite during retrograde metamorphism and exhumation of this domain. The crystallization of this syn-kinematic pegmatite at $1064 \pm 15 \mathrm{Ma}$ (Group $1,{ }^{207} \mathrm{~Pb} /{ }^{206} \mathrm{~Pb}$ ) therefore provides a time constrain on the top-down-to-the-ESE shearing along the eastern TSZ.

Zircon from sample RS12-040 is interpreted as igneous because of their prismatic shape, oscillatory zoning and high trace elements content (e.g. U, Th, Y, Nb, HREE) (Corfu et al., 2003). The temperature of crystallization of pegmatite RS12-040 $\left(755 \pm 30^{\circ} \mathrm{C}\right)$ is higher as compared to pegmatite RS11-098 $\left(691 \pm 30{ }^{\circ} \mathrm{C}\right)$. This is consistent with the emplacement of pegmatite RS12-040 after peak metamorphic conditions of $820-880{ }^{\circ} \mathrm{C} \pm 50{ }^{\circ} \mathrm{C}$, but before the emplacement of pegmatite RS11-098, which was emplaced during cooling and extension along the eastern TSZ at $1064 \pm 15 \mathrm{Ma}$. The age of 
crystallization of the pegmatite RS12-040 (1082 $\left.\pm 20 \mathrm{Ma},{ }^{207} \mathrm{~Pb} /{ }^{206} \mathrm{~Pb}\right)$ implies a minimum age constraint for deformation and metamorphism related to thrusting and crustal thickening in the Mékinac-Taureau domain. That result is moreover consistent with data of Corrigan and van Breemen (1997) who suggested a lower age limit of $1087 \pm 2$ Ma for the thrusting in the adjacent Shawinigan domain.

\section{7. ${ }^{40} \mathrm{Ar} /{ }^{39} \mathrm{Ar}$ geochronology}

\subsection{Analytical methods}

Amphibole and biotite single grains from the the Mékinac-Taureau domain were dated by the ${ }^{40} \mathrm{Ar} /{ }^{39} \mathrm{Ar}$ method (Géosciences Rennes, UMR CNRS 6118) using a $\mathrm{CO}_{2}$ laser probe. The experimental procedure has been described by Ruffet et al. $(1991,1995)$ and Cathelineau et al. (2012). All plateau and pseudo-plateau ages are displayed at the $2 \sigma$ level. Analytical data, parameters used for calculations (isotopic ratios measured on $\mathrm{K}, \mathrm{Ca}$ and $\mathrm{Cl}$ pure salts; mass discrimination; atmospheric argon ratios; J parameter; decay constant, etc.) and reference sources are available in the supplementary data repository.

Isotopic mineral ages are interpreted to record cooling below the closure temperature $\left(T_{C}\right)$. Closure temperatures for amphibole are difficult to estimate because amphibole diffusivity is influenced by the cooling rate, the size of diffusion domains and ionic porosity (Dahl, 1996; Fortier and Giletti, 1989). On the basis of natural hornblende compositions measured by various authors (i.e. Leake, 1978; Robinson et al., 1982), Dahl (1996) suggested a $\mathrm{T}_{\mathrm{c}}$ range of $480-560{ }^{\circ} \mathrm{C}$, calculated for an effective diffusion radius of $80 \mu \mathrm{m}$ and a cooling rate of $10{ }^{\circ} \mathrm{C} / \mathrm{Ma}$. Harrison (1981) calculated closure temperatures between $500^{\circ} \mathrm{C}$ and $580^{\circ} \mathrm{C}$ for an effective diffusion radius of $80 \mu \mathrm{m}$ and cooling rates in the range of 10 to $500{ }^{\circ} \mathrm{C} / \mathrm{Ma}$. The closure temperature was revised to $550-650{ }^{\circ} \mathrm{C}$ by Villa (1998) using Dahl's (1996) experiments suggesting that, depending on its lattice characteristics, hornblende may form a closed system for Ar diffusion at temperatures as high as $580^{\circ} \mathrm{C}$ under cooling rates of $0.7 \mathrm{~K} / \mathrm{Ma}$ (Villa et al., 1996). Recent re-assessments of the closure temperature for biotite suggest that it may be as high as $450^{\circ} \mathrm{C}$ (e.g. Allaz, 2008; Allaz et al., 2011; Villa and Puxeddu, 1994), $150^{\circ} \mathrm{C}$ higher than the commonly accepted temperature of $300{ }^{\circ} \mathrm{C}$ (ex: Dodson, 1973; Harrison et al., 1985). In this study, we will consequently use a $T_{c}$ range value of $550-600{ }^{\circ} \mathrm{C}$ and around $450{ }^{\circ} \mathrm{C}$ for Ca-amphibole and biotite, respectively. 


\subsection{Results}

Six samples containing coarse amphibole and/or biotite were collected in the Mékinac-Taureau and the Shawinigan domains to investigate the cooling history of the area through ${ }^{40} \mathrm{Ar} /{ }^{39} \mathrm{Ar}$ geochronology (See Fig. 2 for locations and supplementary data table 3 for complete results). With one exception, all samples yielded undisturbed plateau ages for both amphibole and biotite (Fig. 12, Table 2). Samples RS11-002 and RS11-115 come from two amphibole- and biotite-rich mafic layers transposed into parallelism with the hosting orthogneiss foliation $\left(S_{n}\right)$ in the interior of the Mékinac-Taureau domain, and located, respectively, $\sim 11$ and $\sim 9 \mathrm{~km}$ structurally below the eastern TSZ. They yielded amphibole plateau ages of 998.6 \pm 7.4 Ma and 1010.0 \pm 7.4 Ma, respectively (Fig. 12A and 12B). Biotite plateau ages of $923.2 \pm 7.0 \mathrm{Ma}$ and $969.8 \pm 7.2 \mathrm{Ma}$, respectively, were also obtained from these samples (Fig. 12A and 11B). Sample RS11-015 comes from a metapelite layer located $\sim 3 \mathrm{~km}$ below the TSZ and contains biotite but not amphibole. The biotite spectrum defines a plateau at $926.1 \pm 7.0 \mathrm{Ma}$ (Fig. 12C). Sample RS11-089 is a biotite-free amphibolite layer located within the eastern TSZ, on the MékinacTaureau domain side, that yielded an amphibole plateau age of $1031.6 \pm 7.6 \mathrm{Ma}$ (Fig. 12D). Finally, two samples were collected in the Shawinigan domain: RS11-113 is a biotite and amphibole bearing intermediate orthogneiss whereas RS11-105 is an amphibole-free metapelite. These samples are respectively located $\sim 1 \mathrm{~km}$ and $\sim 4 \mathrm{~km}$ structurally above the eastern TSZ. Amphibole in sample RS11-113 yielded a pseudo-plateau age of $1022.3 \pm 7.6 \mathrm{Ma}$ with a younger perturbation at $1012.3 \pm 8.0 \mathrm{Ma}$ (Fig. 12E). Its biotite spectrum defines a plateau at 930.4 $\pm 7.0 \mathrm{Ma}$ (Fig. 12E). Sample RS11-105 yielded a biotite cooling age of $905.8 \pm 6.8 \mathrm{Ma}$ (Fig. 12F).

\subsection{Interpretation of ${ }^{40} \mathrm{Ar}^{39} \mathrm{Ar}$ ages}

As discussed, ${ }^{40} \mathrm{Ar}-{ }^{39} \mathrm{Ar}$ ages provide timing constraints on cooling of the area through the closure temperature of amphibole $\left(550-600^{\circ} \mathrm{C}\right)$ and biotite $\left(450^{\circ} \mathrm{C}\right)$. The youngest amphibole ages $(998.6 \pm 7.4$ $\mathrm{Ma}$ and $1010.0 \pm 7.4 \mathrm{Ma}$ ) were obtained from the interior of the Mékinac-Taureau domain, whereas the oldest ( 1031.6 $\pm 7.6 \mathrm{Ma}$ ) was from the amphibolite located within the eastern TSZ. A sample from the Shawinigan domain yielded an intermediate age of $1022.3 \pm 7.6 \mathrm{Ma}$. Unsurprisingly, all amphibole ages are younger than $\sim 1060 \mathrm{Ma}$, the age of shearing along the eastern TSZ when rocks were at $\sim 700{ }^{\circ} \mathrm{C}$ (see section 6).

An interesting younging trend is identified from the eastern TSZ towards the interior of the 
Mékinac-Taureau domain. Amphibole sample RS11-113 located 1 km above the eastern TSZ does not fit in this trend, but the perturbation of its spectrum limits the confidence we have on this date and the interpretations we can make from this sample. Corrigan (1995) explained a similar younging trend from the Tawachiche shear zone towards the Mékinac-Taureau domain by the progressive cooling of the footwall downwards from the detachment surface (e.g. England and Jackson 1987; Hodges et al., 1993; Ruppel et al., 1988). In this study, we have shown the importance of the eastern TSZ for the exhumation of the Mékinac-Taureau domain and consequently propose that cooling may have propagated from this shear zone towards the interior of the Mékinac-Taureau domain, as suggested by the younging trend of amphibole cooling ages in that direction.

Biotite cooling ages vary from $\sim 905$ to $\sim 970 \mathrm{Ma}$ and do not show a pattern that is similar to amphibole cooling ages. For samples containing both amphibole and biotite, the time gap between cooling through the $T_{c}$ of amphibole and the $T_{c}$ of biotite varies from 40 to 90 m.y. This correspond to a cooling rate of 1.36 to $3.10{ }^{\circ} \mathrm{C} / \mathrm{m} . \mathrm{y}$. for the interval $\sim 1020-920 \mathrm{Ma}$, assuming closure temperatures of $\sim 575^{\circ} \mathrm{C}$ and $450{ }^{\circ} \mathrm{C}$ for amphibole and biotite, respectively. This is comparable to the cooling rate of 1.1 to $2.5^{\circ} \mathrm{C} / \mathrm{m}$.y. calculated by Corrigan (1995) for the interval 1040-990 Ma.

\section{Discussion}

\subsection{Metamorphic history and timing constraints}

This study reveals the presence of the eastern TSZ, a major normal-sense shear zone that separates two domains of contrasting metamorphic history. We conducted conventional thermobarometry on granulites of the Mauricie area because of the evidence for limited to absent effects of retrograde reactions following complete re-equilibration, highlighted by the flat zoning profiles in all garnet grains of this study (Fig. 6). Inasmuch as complete chemical homogenization of garnet requires several tens of m.y. at high temperature (see Caddick et al., 2010), and because it is difficult to ascertain that the calculated P-T conditions truly represent the highest P-T conditions attained by the rocks, results presented herein likely represent metamorphic conditions that prevailed during homogenization and are thus considered minimum estimates of the peak P-T conditions. Our results, summarized in Fig. 13, indicate that rocks in the interior of the Mékinac-Taureau domain located $5.5 \mathrm{~km}$ below the eastern TSZ record metamorphic peak conditions of $\sim 1075 \mathrm{MPa}$ and $\sim 825^{\circ} \mathrm{C}$. In the amphibolite sample RS11-082B, collected within the eastern TSZ, P-T values calculated with minerals 
NOTICE: this is the author's version of a work that was accepted for publication in Precambrian Research. Changes resulting from the publishing process, such as peer review, editing, corrections, structural formatting, and other quality control mechanisms may not be reflected in this document. Changes may have been made to this work since it was submitted for publication. A definitive version was subsequently published in Precambrian Research, 257, (Feb 2015). doi: 10.1016/j.precamres.2014.11.012

interpreted as relict of the former peak assemblage yielded values similar to those calculated in the interior of the domain, whereas P-T values calculated with retrograde minerals interpreted as synkinematic with normal shearing yielded P-T values similar to those registered in metapelite from the external zone of the Mékinac-Taureau domain ( 800 to $650 \mathrm{MPa}$ and 775 to $675{ }^{\circ} \mathrm{C}$ ). In contrast, metapelite from the Shawinigan domain records P-T conditions varying from 850 to $625 \mathrm{MPa}$ and from 775 to $700{ }^{\circ} \mathrm{C}$. Although evidence for higher metamorphic conditions are lacking, it is impossible to rule out the possibility that these P-T conditions reflects homogenization during retrograde metamorphism from peak conditions similar to that recorded in the Mekinac-Taureau domain. Nevertheless, it is noteworthy that these P-T values are similar to those from the retrogressed metapelite and amphibolite samples of the Mékinac-Taureau domain.

An important finding of this study is the demonstration that the TSZ on the eastern flank of the Mekinac-Taureau domain is a normal shear zone. Its presence is revealed by an increase in qualitative strain, marked by a much better developed stretching lineation and by numerous shear-sense indicators. Timing constraint on the normal-sense shearing along the eastern TSZ is provided by the emplacement of the syn-kinematic pegmatite, RS11-098, that yielded a ${ }^{207} \mathrm{~Pb} /{ }^{206} \mathrm{~Pb}$ age of $1064 \pm 15 \mathrm{Ma}$, and for which the temperature of crystallization of zircon $\left(\sim 700^{\circ} \mathrm{C} \pm 30^{\circ} \mathrm{C}\right)$ is consistent with the temperature recorded for retrograde conditions during shearing by the amphibolite RS11-082B (720 \pm $60^{\circ} \mathrm{C}$ ). Although this age overlaps within errors with that of pegmatite sample RS12-040 from within the Mékinac-Taureau domain, which yielded a ${ }^{207} \mathrm{~Pb} /{ }^{206} \mathrm{~Pb}$ age of $1082 \pm 20 \mathrm{Ma}$, the absolute ages of the two pegmatite samples and the difference between them are consistent with previously published ages for the area. Indeed, the minimum age of $1082 \mathrm{Ma}$ for thrust-related deformation and accompanying metamorphism indicated by pegmatite sample RS12-040 is consistent with an age of $1087 \pm 2$ Ma for a syn-kinematic leucosome from the Shawinigan domain (Corrigan and van Breemen, 1997), whereas the $\sim 1064 \mathrm{Ma}$ age for pegmatite sample RS11-098 is consistent with the $1065 \pm 1$ Ma age for a pegmatite emplaced during normal shearing along the Tawachiche shear zone, located $\sim 10 \mathrm{~km}$ east of the study area (Fig. 14A; Corrigan and van Breemen,1997). Although quantitative assessment of the amount of vertical displacement along the eastern TSZ remains impossible with available data, a minimum estimate is provided by the $340 \mathrm{MPa}$ difference in paleopressures (converted to depth by assuming a lithostatic gradient of $30 \mathrm{MPa} / \mathrm{km}$ (Winter, 2001)) between peak and retrograde pressure conditions calculated for the amphibolite sample RS11-082B. Consequently, a minimum of $\sim 11 \mathrm{~km}$ of exhumation occurred during 
normal shearing along the eastern TSZ for which the best timing estimate is provided by the 1064 Ma age of pegmatite RS11-098.

Finally, ${ }^{40} \mathrm{Ar} /{ }^{39} \mathrm{Ar}$ data on amphibole and biotite provided time constraints on the cooling of the area. Based on amphibole and biotite ${ }^{40} \mathrm{Ar} /{ }^{39} \mathrm{Ar}$ ages, respectively, the Mauricie area cooled below 550$600{ }^{\circ} \mathrm{C}$ at $\sim 1030-1000 \mathrm{Ma}$ and below $450{ }^{\circ} \mathrm{C}$ at 970-900 Ma. Amphibole cooling ages define a younging trend from the eastern TSZ towards the interior of the Mékinac-Taureau domain (Fig. 13).

\subsection{Mode of exhumation}

Exhumation of mid-crustal rocks in the hinterland of orogens can occur in several different tectonic contexts, notably: (1) an orogenic wedge controlled by the critical taper theory, (2) diapirism (e.g. Calvert et al., 1999; Gervais et al., 2004; Teyssier and Whitney, 2002), (3) syn-convergent channel flow (e.g. Beaumont et al., 2001, 2006, Godin et al., 2006) or (4) post-convergent orogenic collapse and metamorphic core complex (MCC) development (e.g. Brun et al., 1994; Rey et al., 2009; Tirel, 2004; Tirel et al., 2004, 2006, 2008). Here, we compare the tectono-metamorphic characteristics of the Mauricie area with distinguishing features expected from these various exhumation modes.

The regional deformation pattern in the Mauricie area is characterized by a dome-shaped foliation pattern parallel to the lithotectonic boundaries and dipping away from the interior of the Mékinac-Taureau domain (Fig. 2). This regional foliation is considered as the result of thrust-related deformation prior to 1082 Ma in the Mékinac-Taureau domain (this study) and the Shawinigan domain (Corrigan and van Breemen, 1997), although doming of this foliation might be related to the exhumation process. According to Corrigan and van Breemen (1997), thrust faults were located at structural levels above the present exposure of the units. Regional deformation is associated with high-grade metamorphism and partial melting in both domains, migmatites being particularly extensive in the upper structural levels of the Mékinac-Taureau domain. Strain increases in the vicinity of lithotectonic boundaries, i.e. the eastern Taureau and the Tawachiche shear zones. As argued above, the eastern TSZ played a significant role in the exhumation of the Mékinac-Taureau domain at 1064 Ma. However, the Tawachiche shear zone must also be considered when assessing the exhumation history of the Mauricie area. Corrigan and van Breemen (1997) dated syn- and late-extension pegmatites, constraining NNEdirected extension along the Tawachiche shear zone, between $1065 \pm 1$ and $1036+4 /-2 \mathrm{Ma}$. Combined with data from our study, this suggests that ESE-directed extension along the eastern TSZ has been 
coeval, within uncertainty, with NNE-directed extension along the Tawachiche shear zone. The average directions of tectonic transport on both shear zones are almost at right angle from each other (Fig. 14A). Predominance of normal-sense structures, lack of steep flattening structures and reverse-sense shear zones in the area (e.g. Gervais and Brown, 2011 and references therein), and extensive partial melting of the rock units, limiting the maintenance of a wedge geometry, are all against the orogenic wedge model (Vanderhaeghe et al., 2003). On the other hand, regional foliation conformable to discontinuities and an increase in finite strain towards normal-sense shear zones are structural characteristics common to diapirism, channel flow and MCC formation.

Diapirs are characterized by a radial distribution of stretching lineations, vertical flow in their trunk and horizontal flattening at their apex (e.g. Dixon, 1975). As shown in Fig. 14A, stretching lineations within the TSZ and Tawachiche shear zones flanking the SE and E flanks of the MékinacTaureau and Shawinigan domains, respectively, are orthogonal to each other. However, the distribution of these lineations do not correspond to a radial pattern around an hypothetical diapir, but are rather associated with two distinct shear zones located at different structural levels. The interior of the Mékinac-Taureau domain presents a strong foliation dipping away from its core, a feature common to the apex of diapirs. However, relict vertical fabric attesting for vertical flow during diapiric ascent, commonly observed despite the horizontal fabric overprinting (e.g. Gervais et al., 2004), are lacking in the interior of the Mékinac-Taureau domain, despite the $\sim 12 \mathrm{~km}$ of vertical section exposed along the tilted transect of the study area. Furthermore, data suggesting an older deformation in the interior of the domain than along the bounding normal-sense shear zones would not be compatible with diapirism. Finally, a buoyancy contrast is required to initiate and maintain diapirism (Teyssier and Whitney, 2002). In the Mauricie area, it is not clear whether the relatively small area of garnet-rich metapelite in the StBoniface paragneiss and of mafic volcanic rocks in the Portneuf-Mauricie domain constituted a sufficient volume of dense rocks to initiate diapirism. Due to poor compatible structural evidence, apparently incompatible timing of deformation and lack of an obvious efficient driving mechanism, diapirism is not proposed as the exhumation process for the Mauricie area.

Extrusion of mid-crustal material by channel flow involves a melt-weakened ductile layer bounded by a thrust shear zone below and a normal shear zone above (Godin et al., 2006). Key characteristics of such model that are testable in the study area include: 1) high shear strain commonly distributed 
NOTICE: this is the author's version of a work that was accepted for publication in Precambrian Research. Changes resulting from the publishing process, such as peer review, editing, corrections, structural formatting, and other quality control mechanisms may not be reflected in this document. Changes may have been made to this work since it was submitted for publication. A definitive version was subsequently published in Precambrian Research, 257, (Feb 2015). doi: 10.1016/j.precamres.2014.11.012

through the channel; 2) coeval reverse- and normal-sense shearing at the base and top of the channel, respectively; 3 ) uniform cooling ages at any transverse sections of the channel and progressively older cooling ages from the front towards the rear of the channel (Gervais and Brown, 2011; Godin et al., 2006). If such a mechanism occurred in the Mauricie area, the eastern TSZ would be the upper normalsense shear zone and the underlying Mekinac-Taureau domain would be the upper portion of the channel. Although deformation within the latter is interpreted as resulting from NW thrusting, the variable and poorly developed lineation (Fig. 2) does not suggest high shear strain. Furthermore, although more robust geochronological data would be desirable, available data suggest that penetrative deformation within the putative channel occurred prior to 1082 Ma, whereas normal shearing along its upper shear zones, the eastern TSZ and the Tawachiche shear zone, was occurring at 1064 Ma and probably continued until $1036 \mathrm{Ma}$, the age of a "late-extensional" pegmatite emplaced within the Tawachiche shear zone (Corrigan and van Breemen, 1997). Evidence for synchroneity of reverse- and normal-sense shearing, characteristic 2 above, is therefore lacking. Finally, as a channel flows towards the surface, its frontal part should cool before its rear. The trend of hornblende argon cooling age decreasing towards the core of the Mekinac-Taureau domain could be compatible with this characteristic, although it could also reflect a trend towards deeper structural levels. Consequently, although more data are needed, especially at the northern end of the Mekinac-Taureau domain, available data from the Mauricie area do not seem to support the channel flow hypothesis as a single exhumation mechanism. The possibility of an earlier phase of mid-crustal flow overprinted by another mechanism cannot however be entirely excluded.

Metamorphic core complexes are characterized by a dome of high-grade metamorphic rocks in the footwall, covered by non-metamorphic upper crustal units (or units that have experienced an earlier metamorphic event) in the hanging wall of a normal-sense shear zone, which is generally planar or slightly convex upward at the apex of the dome and dips away from that dome on its flanks (e.g. Lister and Davis, 1989; Tirel 2006; Wernicke, 1985). In the Mauricie area, the Mékinac-Taureau domain underwent high-grade metamorphism before $1082 \mathrm{Ma} \mathrm{(1075} \mathrm{MPa} \mathrm{and} 825^{\circ} \mathrm{C}$; this study) and the Shawinigan domain underwent coeval and slightly lower-grade metamorphism (625-850 MPa and 700$775{ }^{\circ} \mathrm{C}$, this study; Corrigan and van Breemen, 1997). In contrast, peak metamorphic conditions in the overlying Portneuf-Mauricie domain was significantly lower (300-600 MPa and 550-700 ${ }^{\circ} \mathrm{C}$; Corrigan, 1995; Lévesque, 1995) and most likely much older (estimated at 1400 Ma by Corrigan and van 
Breemen, 1997). This geometry of domains of contrasted metamorphic grades separated by gently dipping $\left(\sim 20-30^{\circ}\right)$ normal-sense shear zones that were active after the main episode of deformation and metamorphism in the dome core are compatible to that expected on the flank of a MCC, although two major normal shear zones are present, instead of a single decollement horizon (Fig. 14C). Furthermore, the late, brittle-ductile normal faults observed in the Shawinigan domain, south of the TSZ (i.e. structurally above the shear zone; Fig. 4B) could be compatible with the synthetic structures related to the main detachment commonly observed in the hanging walls of MCCs (e.g. Wernicke, 1985). The top bounding shear zone of MCCs is commonly retrograde when compared with the metamorphic grade of the footwall (Dallmeyer et al. 1986; Gibson et al. 1988; Lister and Davis, 1989). This is the case for the eastern TSZ, where retrograde metamorphic textures and retrograde P-T conditions were observed in an amphibolite sampled within the shear zone. Corrigan (1995) and Corrigan and van Breeman (1997) also suggested that the Tawachiche shear zone was retrograde as compared to peak metamorphism in the underlying Shawinigan domain. The trend of cooling ages younging towards the core of the dome is a feature uncommon to classic metamorphic core complexes (e.g. Sullivan and Snooke, 2007), but similar cooling trends are nevertheless reported in the literature (e.g. Brun and Sokoutis, 2007) and can be inferred from results of numerical modeling (Tirel et al. 2008). MCC development is commonly associated with unidirectional direction of extension (e.g. Doughty et al., 2007; Lana et al., 2010; Lister and Davis, 1989), as opposed to the orthogonal trends of stretching lineation associated with the Tawachiche and eastern TSZ (Fig. 14A). Although uncommon, examples of core complexes with >1 directions of extension however exist in nature. Hill et al., (1992) and Hill (1994), for instance, described the d'Entrecasteaux Island MCC and argued for the existence of bounding shear zones with directions of shearing at $90{ }^{\circ} \mathrm{C}$ from one another. Although present data suggest that the eastern Taureau and Tawachiche shear zones are coeval within uncertainty, the possibility of temporally discrete phases with orthogonal direction of extension cannot be firmly ruled out. Whether both shear zones were coeval or not, this pattern is best explained if orogenic collapse was of the gravity-driven fixed-boundary mode (as in the terminology of Rey et al., 2001) in contrast to the free-boundary mode of most cordilleran MCC that formed in a regional tensional stress regime. The fixed mode is driven by vertical $\sigma 1$ due to gravitational forces rather than by horizontal, orogen-perpendicular tension along $\sigma 3$. In 3D, the fixed mode should result in $\sigma 2 \approx \sigma 3$ and, in turn, could explain the pattern of orthogonal lineations observed in the normal-sense shear zones bounding the complex. A quasi radial pattern of extension is also observed at the scale of the Grenville Province (Rivers; 2012). Furthermore, a MCC not developing by a 
rolling-hinge mechanism (Axen and Bartley, 1997) could potentially explain the difference in trends of cooling ages as well. Even if some characteristics of the Mauricie area do not correspond to that of a typical cordilleran MCC, we consider that gravitational collapse is the most likely mechanism of exhumation of the Mekinac-Taureau domain. The possibility of an earlier phase of mid-crustal flow preceding the gravitational collapse cannot be confidently ruled out, but data suggest that channel flow alone cannot explain the geological architecture observed in the Mauricie area. Results of this study, therefore, support the conceptual model of gravitational collapse presented by Rivers $(2008,2012)$.

\section{Conclusions}

Structural analysis, thermobarometry, U-Pb and ${ }^{40} \mathrm{Ar} /{ }^{39} \mathrm{Ar}$ geochronology on selected samples of the Mauricie area provided data essential to the reconstruction of the tectono-metamorphic history of the area:

1) Peak metamorphism in the Mékinac-Taureau domain reached P-T conditions of $1000-1100$ $\mathrm{MPa}$ and $820-880{ }^{\circ} \mathrm{C}$ prior to $1082 \pm 20 \mathrm{Ma}$. This metamorphic event is considered as the result of northwestward thrusting and regional-scale crustal thickening.

2) Retrograde conditions varying from 800 to $650 \mathrm{MPa}$ and from 775 to $675^{\circ} \mathrm{C}$ were recorded in the upper structural levels of the Mékinac-Taureau domain.

3) The Shawinigan domain records P-T conditions varying from 850 to $625 \mathrm{MPa}$ and from 775 to $700{ }^{\circ} \mathrm{C}$, values that are equivalent or of a slightly lower metamorphic grade as compared with retrogressed samples from the margin of the Mékinac-Taureau domain.

4) The contact between the Mékinac-Taureau and the Shawinigan domains is marked by a normal-sense shear zone with a top-down-to-the-ESE sense of shear, the eastern TSZ, that was active at $\sim 1064 \pm 15 \mathrm{Ma}$, during and/or after retrograde metamorphism documented in the Mékinac-Taureau domain.

5) Normal-sense shearing along the eastern TSZ is coeval, within uncertainty, with NNE-directed normal-sense shearing along the Tawachiche shear zone (Corrigan, 1995; Corrigan and van Breemen, 1997).

6) The area cooled below $550-600{ }^{\circ} \mathrm{C}$ at $1000-1030 \mathrm{Ma}$ and below $450{ }^{\circ} \mathrm{C}$ at $\sim 900-970 \mathrm{Ma}$.

7) Structural and metamorphic characteristics of the Mauricie area are similar to those expected from a metamorphic core complex formed during post-convergent orogenic collapse in a gravity-driven fixed-boundary mode. The Mékinac-Taureau and Shawinigan domains were thus probably exhumed by a similar process. Our study thus supports the orogenic collapse 
model of Rivers $(2008,2012)$ for the exhumation of mid-crustal metamorphic core complexes in the Grenville Province.

\section{Acknowledgments}

This work is part of a M.Sc. thesis undertaken by Renaud Soucy La Roche at Université du Québec à Montréal (UQÀM). Renaud Soucy La Roche received graduate scholarships from the Natural Sciences and Engineering Research Council of Canada (NSERC) and the Fonds de recherche du Québec - Nature et Technologies (FRQNT). The project was financed by a NSERC research grant held by Alain Tremblay (PG 105669) and by internal funding provided to Félix Gervais by École Polytechnique de Montréal. Morgann Perrot and Xavier Vasseaud are thanked for field assistance. Lang Shi from the Electron Microprobe Laboratory of the McGill University is thanked for his assistance during the acquisition of mineral chemical compositions for thermobarometry. Michelle Laithier is also thanked for her useful advices on figures conception. A previous version of this manuscript benefited from comments by Alexandre Zagorevski and Léopold Nadeau. We also thank Toby Rivers and Aphrodite Indares for critical, but constructive, reviews of the manuscript and Randall Parrish for editorial handling.

\section{References}

Allaz, J., 2008. Metamorphic evolution in the northern Central Alps: linking ${ }^{39} \mathrm{Ar}-{ }^{40} \mathrm{Ar}$ dating with thermobarometry (Ph.D. thesis). Universität Bern, Bern, Switzerland, 224 pp.

Allaz, J., Engi, M., Berger, A., Villa, I.M., 2011. The Effects of Retrograde Reactions and of Diffusion on ${ }^{40} \mathrm{Ar}-{ }^{39} \mathrm{Ar}$ Ages of Micas. Journal of Petrology, 52(4), 691-716.

Axen, G.J., Bartley, J.M. 1997. Field tests of rolling hinges: Existence, mechanical types, and implications for extensional tectonics. Journal of Geophysical Research: Solid Earth, 102(B9), 20515-20537.

Barton, J.M.Jr., Doig, R., 1972. Rb-Sr Isotopic studies of the Lac Croche Complex, Grenville Province, Quebec. Canadian Journal of Earth Sciences, 9(9), 1180-1186.

Beaumont, C.J., Jamieson, R.A., Nguyen, M.H., Lee, B., 2001. Himalayan tectonics explained by extrusion of a low-viscosity crustal channel coupled to focused surface denudation. Nature, 414(6865), 738742.

Beaumont, C.J., Nguyen, M. H., Jamieson, R. A., Ellis, S., 2006. Crustal flow modes in large hot orogens. Geological Society, London, Special Publications, 268(1), 91-145.

Berman, R.G., 1988. Internally-consistent thermodynamic data for stoichiometric minerals in the system K2O-Na2O-CaO-MgO-FeO-Fe2O3-Al2O3-SiO2-TiO2-H2O-CO2-O. Journal of Petrology, 29(2), 445-522.

Berman, R.G., 1991. Thermobarometry using multi-equilibrium calculations: a new technique, with petrological applications. Canadian Mineralogist, 29(4), 833-855.

Berman, R.G., 2007. winTWQ (version 2.3): A software package for performing internally-consistent 
NOTICE: this is the author's version of a work that was accepted for publication in Precambrian Research. Changes resulting from the publishing process, such as peer review, editing, corrections, structural formatting, and other quality control mechanisms may not be reflected in this document. Changes may have been made to this work since it was submitted for publication. A definitive version was subsequently published in Precambrian Research, 257, (Feb 2015). doi: 10.1016/j.precamres.2014.11.012

thermobarometric calculations. Geological Survey of Canada, Open File, 5462 (revised).

Berman, R.G., Aranovich, L.Y., Rancourt, D.G., Mercier, P.H.J., 2007. Reversed phase equilibrium constraints on the stability of Mg-Fe-Al biotite. American Mineralogist, 92, 139-150.

Brun, J. P., Sokoutis, D., 2007. Kinematics of the southern Rhodope core complex (North Greece). International Journal of Earth Sciences, 96(6), 1079-1099.

Brun, J.P., Sokoutis, D., van den Driessche, J., 1994. Analogue modeling of detachment fault systems and core complexes. Geology, 22(4), 319-322.

Caddick, M.J., Konopasek, J., Thompson, A.B., 2010. Preservation of garnet growth zoning and the duration of prograde metamorphism. Journal of petrology, 51(11), 2327-2347.

Calvert, A.T., Gans, P.B., Amato, J.M., 1999. Diapiric ascent and cooling of a sillimanite gneiss dome revealed by ${ }^{40} \mathrm{Ar} /{ }^{39} \mathrm{Ar}$ thermochronology: the Kigluaik Mountains, Seward Peninsula, Alaska. Geological Society, London, Special Publications, 154(1), 205-232.

Carmichael, D.M. 1978. Metamorphic bathozones and bathograds; a measure of the depth of postmetamorphic uplift and erosion on the regional scale. American Journal of Science, 278(6), 769-797.

Cathelineau M., Boiron M.C., Fourcade S., Ruffet G., Clauer N., Belcourt O., Coulibaly Y., Banks D.A., Guillocheau F., 2012. A major Late Jurassic fluid event at the basin/basement unconformity in western France: ${ }^{40} \mathrm{Ar} /{ }^{39} \mathrm{Ar}$ and $\mathrm{K}-\mathrm{Ar}$ dating, fluid chemistry, and related geodynamic context. Chemical Geology, 322-323, 99-120.

Corfu F., Hanchar, J.M., Hoskin, P.W.O., Kinny, P., 2003. Atlas of zircon textures. Reviews in Mineralogy and Geochemistry, 53(1), 469-500.

Corrigan, D. 1995. Mesoproterozoic evolution of the south-central Grenville orogen: structural, metamorphic, and geochronologic constraints from the Mauricie transect (Ph.D. thesis). Carleton University, Ottawa, Canada, 308 pp.

Corrigan, D., van Breemen, O., 1997. U-Pb age constraints for the lithotectonic evolution of the Grenville Province along the Mauricie transect, Québec. Canadian Journal of Earth Sciences, 34(3), 299-316.

Dahl, P.S., 1996. The effects of composition on retentivity of argon and oxygen in hornblende and related amphiboles: a field-tested empirical model. Geochimica et Cosmochimica Acta, 60(19), 36873700.

Dahlen, F.A., 1990. Critical taper model of fold-and-thrust belts and accretionary wedges. Annual Review of Earth and Planetary Sciences, 18, 55-99.

Dale, J., Powell, R., White, R.W., Elmer, F.L., Holland, T.J.B., 2005. A thermodynamic model for Ca-Na clinoamphiboles in Na2O-CaO-FeO-MgO-Al2O3-SiO2-H2O-O for petrological calculations. Journal of Metamorphic Geology, 23(8), 771-791.

Dallmeyer, R.D., Snoke, A.W., McKee, E.H., 1986. The Mesozoic-Cenozoic tectonothermal evolution of the Ruby Mountains, East Humboldt Range, Nevada: A Cordilleran Metamorphic Core Complex. Tectonics, 5(6), 931-954.

Davidson, C., Schmid, S.M., Hollister, L.S., 1994. Role of melt during deformation in the deep crust. Terra Nova, 6(2), 133-142.

Dewey, J.F., 1988. Extensional collapse of orogens. Tectonics, 7(6), 1123-1139.

Dewey, J.F., Burke, K.C., 1973. Tibetan, Variscan, and Precambrian basement reactivation: products of continental collision. The Journal of Geology 81(6), 683-692.

Dixon, J. M., 1975. Finite strain and progressive deformation in models of diapiric structures. 
Tectonophysics, 28(1), 89-124.

Dodson, M.H., 1973. Closure temperature in cooling geochronological and petrological systems. Contributions to Mineralogy and Petrology, 40(3), 259-274.

Doig, R., 1991. U-Pb zircon dates of Morin Anorthosite suite rocks, Grenville Province, Quebec. Journal of Geology, 99(5), 729-738.

Doughty, P.T., Chamberlain, K.R., Foster, D.A., Grant, S.S., 2007. Structural, metamorphic, and geochronologic constraints on the origin of the Clearwater core complex, northern Idaho. Geological Society of America Special Papers, 433, 211-241.

England, P., Jackson, J., 1987. Migration of the seismic-aseismic transition during uniform and nonuniform extension of the continental lithosphere. Geology, 15(4), 291-294.

England, P., Molnar, P., 1990. Surface uplift, uplift of rocks, and exhumation of rocks. Geology, 18(12), 1173-1177.

Essene, J.E., 1989. The current status of thermobarometry in metamorphic rocks. Geological Society, London, Special Publication, 43(1), 1-44.

Ferriss, E.D.A., Essene, E.J., Becker, U., 2008. Computational study of the effect of pressure on the Ti-inzircon geothermometer. European Journal of Mineralogy, 20(5), 745-755.

Ferry, J.M., Watson, E.B., 2007. New thermodynamic models and revised calibrations for the Ti-in-zircon and Zr-in-rutile thermometers. Contributions to Mineralogy and Petrology, 154(4), 429-437.

Fortier, S.M., Giletti, B.J., 1989. An empirical model for predicting diffusion coefficients in silicate minerals. Science, 245(4925), 1481-1484.

Friedman, R.M., Martignole, J., 1995. Mesoproterozoic sedimentation, magmatism, and metamorphism in the southern part of the Grenville Province (western Quebec): U-Pb geochronological constraints. Canadian Journal of Earth Sciences, 32(12), 2103-2114.

Fuhrman, M.L., Lindsley, D.H., 1988. Ternary-feldspar modeling and thermometry. The American Mineralogist, 73(3-4), 201-216.

Gapais, D., Cagnard, F., Gueydan, F., Barbey P., Ballèvre M., 2009. Mountain building and exhumation processes through time: inferences from nature and models. Terra Nova, 21(3), 188-194.

Gervais, F., Brown, R.L., 2011. Testing modes of exhumation in collisional orogens: Synconvergent channel flow in the southeastern Canadian Cordillera. Lithosphere, 3(1), 55-75.

Gervais, F., Nadeau, L., Malo, M., 2004. Migmatitic structures and solid-state diapirism in orthogneiss domes, eastern Grenville Province, Canada. Geological Society of America Special Papers, 380, 359378.

Gerya, T.V., Perchuk, L.L., Maresch, W.V., Willner, A.P., 2004. Inherent gravitational instability of hot continental crust: Implications for doming and diapirism in granulite facies terrains. Geological Society of America Special Papers, 380, 97-115.

Gibson, G.M., McDougall, I., Ireland, T.R., 1988. Age constraints on metamorphism and the development of a metamorphic core complex in Fiordland, southern New Zealand. Geology, 16(5), 405-408.

Godin, L., Grujic, D., Law, R.D., Searle, M.P., 2006. Channel flow, ductile extrusion and exhumation in continental collision zones: an introduction. Geological Society, London, Special Publications, 268(1), $1-23$.

Goodspeed, G. E., 1940. Dilation and replacement dikes. The Journal of Geology, 175-195. 
Grove, T.L., Baker, M.B., Kinzler, R.J., 1984. Coupled CaAl-NaSi diffusion in plagioclase feldspar: Experiments and applications to cooling rate speedometry. Geochimical et Cosmochimica Acta, 48(10), 2112-2121.

Hanmer, S., 1988. Ductile thrusting at mid-crustal level, southwestern Grenville Province, Canadian Journal of Earth Sciences, 25(5), 1049- 1059.

Hanmer, S., Passchier, C., 1991. Shear-sense indicators: A review. Ottawa: Geological Survey of Canada, $72 \mathrm{pp}$.

Harrison, T.M., 1981. Diffusion of ${ }^{40} \mathrm{Ar}$ in hornblende. Contribution to Mineralogy and Petrology, 78(3), 324-331.

Harrison, T.M., Duncan, I., McDougall, I., 1985. Diffusion of ${ }^{40} \mathrm{Ar}$ in biotite: temperature, pressure and compositional effects. Geochimica et Cosmochimica Acta, 49(11), 2461-2468.

Hauzenberger, C.A., Robl, J., Stüwe, K., 2005. Garnet zoning in high pressure granulite-facies metapelites, Mozambique belt, SE-Kenya constraints on the cooling history. European journal of mineralogy, 17(1), 43-55.

Hayden L.A., Watson E.B., 2007. Rutile saturation in hydrous siliceous melts and its bearing on $\mathrm{Ti}$ thermometry of quartz and zircon. Earth and Planetary Sciences Letters, 258(3), 561-568

Henry, D.J., Guidotti, C.V., Thomson, J.A., 2005. The Ti-saturation surface for low-to-medium pressure metapelitic biotites: Implications for geothermometry and Ti-substitution mechanisms. American Mineralogist, 90(2-3), 316-328.

Herd, K., Ackerman, D., Windley, B.F., Rondot, J., 1986. Sapphirine-garnet rocks, St. Maurice area, Québec: petrology and implications for tectonics and metamorphism. Geological Association of Canada, Special Paper, 31, 241-253.

Hill, E.J., 1994. Geometry and kinematics of shear zones formed during continental extension in eastern Papua New Guinea. Journal of Structural Geology, 16(8), 1093-1105.

Hill, E.J., Baldwin, S.L., Lister, G.S., 1992. Unroofing of active metamorphic core complexes in the D'Entrecasteaux Islands, Papua New Guinea. Geology, 20(10), 907-910.

Hocq, M., Dufour S., 2002. Compilation Géologique - Réservoir Taureau. Québec: Ministère des Ressources Naturelles et de la Faune.

Hocq, M., Dufour S., 1999. Compilation Géologique - Lac Éveline. Québec: Ministère des Ressources Naturelles et de la Faune.

Hodges, K.V., Burchfiel, B.C., Royden, L.H., Chen, Z., Liu, Y., 1993. The metamorphic signature of contemporaneous extension and shortening in the central Himalayan orogen: data from the Nyalam transect, southern Tibet. Journal of Metamorphic Geology, 11(5), 721-737.

Holdaway, M.J., 2001. Recalibration of the GASP geobarometer in light of recent garnet and plagioclase activity models and versions of the garnet-biotite geothermometer. American Mineralogist, 86(10), 1117-1129.

Holland, T.J.B., Powell, R., 1998. An internally consistent thermodynamic data set for phases of petrological interest. Journal of metamorphic Geology,16(3), 309-343.

Hoskin, P.W.O., Black, L.P., 2000. Metamorphic zircon formation by solid-state recrystallization of protolith igneous zircon. Journal of Metamorphic Geology, 18(4), 423-439.

Hoskin, P.W.O., Shaltegger, U., 2003. The composition of zircon and igneous and metamorphic petrogenesis. Reviews in Mineralogy and Geochemistry, 53(1), 27-62. 
NOTICE: this is the author's version of a work that was accepted for publication in Precambrian Research. Changes resulting from the publishing process, such as peer review, editing, corrections, structural formatting, and other quality control mechanisms may not be reflected in this document. Changes may have been made to this work since it was submitted for publication. A definitive version was subsequently published in Precambrian Research, 257, (Feb 2015). doi: 10.1016/j.precamres.2014.11.012

Hynes, A., Rivers, T., 2010. Protracted continental collision evidence from the Grenville Orogen. Canadian Journal of Earth Sciences, 47(5), 591-620.

Jamieson, R.A., Beaumont, C., Nguyen, M.H., Culshaw, N.G., 2007. Synconvergent ductile flow in variable-strength continental crust: numerical models with application to the western Grenville orogen. Tectonics, 26(5), TC5005.

Jamieson, R.A., Beaumont, C., Warren, C.J., Nguyen, M.H., 2010. The Grenville Orogen explained? Applications and limitations of integrating numerical models with geological and geophysical data. Canadian Journal of Earth Sciences, 47(4), 517-539.

Jourdan, F., Renne. P.R., 2007. Age calibration of the Fish Canyon sanidine ${ }^{40} \mathrm{Ar} /{ }^{39} \mathrm{Ar}$ dating standard using primary K-Ar standards. Geochimimica Cosmochimica Acta, 71(2), 387-402.

Jourdan, F., Verati, C., Féraud. G., 2006. Intercalibration of the $\mathrm{Hb3gr}{ }^{40} \mathrm{Ar} /{ }^{39} \mathrm{Ar}$ dating standard. Chemical Geology, 231(3), 77-189.

Kohn, M.J., Spear, F., 2000. Retrograde net transfer reaction insurance for pressure-temperature estimates. Geology, 28(12), 1127-1130.

Kretz, R., 1983. Symbols for rock-forming minerals. American Mineralogist, 68, 277-279.

Lana, C., Kisters, A., Stevens, G., 2010. Exhumation of Mesoarchean TTG gneisses from the middle crust: Insights from the Steynsdorp core complex, Barberton granitoid-greenstone terrain, South Africa. Geological Society of America Bulletin, 122(1-2), 183-197.

Leake, B.E., 1978. Nomenclature of amphiboles. Canadian Mineralogist, 14(4), 501-520.

Lee, J.Y., Marti, K., Severinghaus, J.P., Kawamura, K., Yoo, H.S., Lee, J.B., Kim, J.S., 2006. A redetermination of the isotopic abundances of atmospheric Ar. Geochimica et Cosmochimica Acta, 70(17), 4507-4512.

Lemieux, É.B., 1992. Analyse structurale de la partie nord du groupe de Montauban, province de Grenville (M.Sc. thesis). Université Laval, Québec, Canada.

Lévesque, S., 1995. Zonation metamorphique et évolution thermique de la region Portneuf-Mauricie, orogène de Grenville (M.Sc. thesis). Université Laval, Québec, Canada.

Lister, G.S., Davis, G.A., 1989. The origin of metamorphic core complexes and detachment faults formed during Tertiary continental extension in the northern Colorado River region, USA. Journal of Structural Geology, 11(1), 65-94.

Ludwig, K.R., 2003. User's Manual for Isoplot 3.00. Berkeley: Geochronology Center.

Mäder, U.K., Percival, J.A., Berman, R.G., 1994. Thermobarometry of garnet-clinopyroxene-hornblende granulites from the Kapuskasing structural zone, Canadian Journal of Earth Sciences, 31(7), 11341145.

Mark, D.F., Stuart, F.M., De Podesta, M., 2011. New high-precision measurements of the isotopic composition of atmospheric argon. Geochimica et Cosmochimica Acta, 75(23), 7494-7501.

Martignole, J., 1975. Le Précambrien dans le sud de la province tectonique de Grenville (Bouclier Canadien) (Doctorat d'état thesis). Université Paul Sabatier, Toulouse, France, 242 pp.

Martignole, J., Friedman, R., 1998. Geochronological constraints on the last stages of terrane assembly in the central part of the Grenville Province. Precambrian Research, 92(2), 145-164.

Nadeau, L., Brouillette, P., 1994. Structural map of the La Tuque area (NTS 31P), Grenville Province, Quebec. Geological Survey of Canada, Open File 2938, échelle 1: 250000. 
NOTICE: this is the author's version of a work that was accepted for publication in Precambrian Research. Changes resulting from the publishing process, such as peer review, editing, corrections, structural formatting, and other quality control mechanisms may not be reflected in this document. Changes may have been made to this work since it was submitted for publication. A definitive version was subsequently published in Precambrian Research, 257, (Feb 2015). doi: 10.1016/j.precamres.2014.11.012

Nadeau, L., Brouillette, P., 1995. Structural map of the Shawinigan area (NTS 31I), Grenville Province, Quebec. Geological Survey of Canada, Open File 3012, échelle 1: 250000.

Nadeau, L., Brouillette, P., Hébert, C., 2009. Geological compilation map of the Portneuf-St.Maurice region, Grenville Province, Quebec (GM 63830). Québec: Ministère des Ressources Naturelles et de la Faune.

Nadeau, L., Corrigan, D., 1991. Preliminary notes of the geology of the St-Maurice tectonic zone, Grenville orogen, Quebec. Geological Survey of Canada, Current research, E, 245-255.

Nadeau, L., Van Breemen, O., 2001. U-Pb Zircon Age and Regional Setting of the Lapeyrère Gabbronorite, Portneuf-Mauricie Region, South Central Grenville Province, Quebec. Geological Survey of Canada, Current research, part F6, 1-8.

Nadeau, L., van Breemen, O., 1994. Do the 1.45-1.39 Ga Montauban group and the La Bostonnais complex constitute a Grenvillian accreted terrane? Geological Association of Canada - Mineralogical Association of Canada annual meeting, Waterloo, abstract volume 19: A81.

Passchier, C. W., Trouw, R.A.J., 2005. Microtectonics ( $2^{\mathrm{e}}$ éd.). Berlin: Springer, 366 pp.

Pattison, D.R.M., 1992. Stability of andalusite and sillimanite and the $\mathrm{Al}_{2} \mathrm{SiO}_{5}$ triple point: constraints from the Ballachulish aureole. The Journal of Geology, 100(4), 423-446.

Pan, Y., 1997. Zircon- and monazite-forming metamorphic reactions at Manitouwadge, Ontario. The Canadian Mineralogist, 35(1), 105-118.

Peck, W.H., DeAngelis, M.T., Meredith, M.T., Morin, E., 2005. Polymetamorphism of marbles in the Morin terrane, Grenville Province, Quebec. Canadian Journal of Earth Sciences, 42(10), 1949-1965.

Peck, W.H., 2012. Reconnaissance geochronology and geochemistry of the Mont-Tremblant gneiss of the Morin terrane, Grenville Province, Québec. Geosphere, 8(6): 1356-1365.

Platt, J.P., 1986. Dynamics of orogenic wedges and the uplift of high-pressure metamorphic rocks. Geological Society of America Bulletin, 97(9), 1037-1053.

Powell, R., Holland, T.J.B., 1988. An internally consistent dataset with uncertainties and correlations: 3. Applications to geobarometry, worked examples and a computer program. Journal of Metamorphic Geology, 6(2), 173-204.

Powell, R., Holland, T.J.B., 1994. Optimal geothermometry and geobarometry. American Mineralogist, 79(1-2), 120-133.

Powell, R., Holland, T.J.B., 2008. On thermobarometry. Journal of Metamorphic Geology, 26(2), 155-179.

Renne, P.R., Balco, G., Ludwig, R.L., Mundil, R., Min. K., 2011. Response to the comment by W.H. Schwarz et al., on "Joint determination of ${ }^{40} \mathrm{~K}$ decay constants and ${ }^{40} \mathrm{Ar} * /{ }^{40} \mathrm{~K}$ for the Fish Canyon sanidine standard, and improved accuracy for ${ }^{40} \mathrm{Ar} /{ }^{39} \mathrm{Ar}$ geochronology" by PR Renne et al. (2010). Geochimica et Cosmochimica Acta, 75(17), 5097-5100.

Renne, P.R., Mundil, R., Balco, G., Min, K., Ludwig R.L., 2010. Joint determination of ${ }^{40} \mathrm{~K}$ decay constants and ${ }^{40} \mathrm{Ar}^{*} /{ }^{40} \mathrm{~K}$ for the Fish Canyon sanidine standard, and improved accuracy for ${ }^{40} \mathrm{Ar} /{ }^{39} \mathrm{Ar}$ geochronology. Geochimica et Cosmochimica Acta 74(18), 5349-5367.

Rey, P.F., Teyssier, C., Whitney, D.L., 2009. Extension rates, crustal melting, and core complex dynamics. Geology, 37(5), 391-394.

Rey, P.F., Vanderhaeghe, O., Teyssier, C., 2001. Gravitational collapse of the continental crust: Definition, regimes and modes. Tectonophysics, 342(3), 435-449.

Ring, U., Brandon, M.T., Lister, G.S., Willet, S.D., 1999. Exhumation Processes. Geological Society, 
NOTICE: this is the author's version of a work that was accepted for publication in Precambrian Research. Changes resulting from the publishing process, such as peer review, editing, corrections, structural formatting, and other quality control mechanisms may not be reflected in this document. Changes may have been made to this work since it was submitted for publication. A definitive version was subsequently published in Precambrian Research, 257, (Feb 2015). doi: 10.1016/j.precamres.2014.11.012

London, Special Publications, 154, 1-27.

Rivers, T., 1997. Lithotectonic elements of the Grenville Province: review and tectonic implications. Precambrian Research, 86(3), 117-154.

Rivers, T., 2008. Assembly and preservation of lower, mid and upper orogenic crust in the Grenville Province - Implications for the evolution of large, hot long-duration orogens. Precambrian Research, 167(3), 237-259.

Rivers, T., 2009. The Grenville Province as a large hot long-duration collisional orogen - insights from the spatial and thermal evolution of its orogenic fronts. Geological Society, London, Special Publication 327(1), 405-444.

Rivers, T., 2012. Upper-crustal orogenic lid and mid-crustal core complexes: signature of a collapsed orogenic plateau in the hinterland of the Grenville Province. Canadian Journal of Earth Sciences, 49(1), 1-42.

Rivers, T., Martignole, J., Gower, C.F., Davidson, A., 1989. New tectonic divisions of the Grenville Province, southeast Canadian shield. Tectonics, 8(1), 63-84.

Rivers, T., Culshaw, N., Hynes, A., Indares, A., Jamieson, R., \& Martignole, J. (2012). The Grenville Orogen-A post-Lithoprobe perspective. Tectonic styles in Canada: The LITHOPROBE perspective. In tectonic styles in Canada: the Lithoprobe perspective. Edited by JA Percival, FA Cook, and RM Clowes. Geological Association of Canada Special Paper, 49, 97-238.

Robinson, P., Spear, F.S., Schumacher, J.C., Laird, J., Klein, C., Evans, B.W., Doolan, B.L., 1982. Phase relations of metamorphic amphiboles: natural occurrence and theory. Reviews in Mineralogy and Geochemistry, 9(1), 1-211.

Roddick, J.C., 1983. High precision intercalibration of ${ }^{40} \mathrm{Ar} /{ }^{39} \mathrm{Ar}$ standards. Geochimica et Cosmochimica Acta, 47(5), 887-898.

Rosenberg, C.L., Handy, M.R., 2005. Experimental deformation of partially melted granite revisited: implications for the continental crust. Journal of Metamorphic Geology, 23(1), 19-28.

Royden, L., 1996. Coupling and decoupling of crust and mantle in convergent orogens: Implications for strain partitioning in the crust. Journal of Geophysical Research: Solid Earth, 101(B8), 17679-17705.

Ruffet, G., Féraud, G., Amouric, M., 1991. Comparison of ${ }^{40} \mathrm{Ar} /{ }^{39} \mathrm{Ar}$ conventional and laser dating of biotites fram the North Trégor Batholith. Geochimica et Cosmochimica Acta, 55(6), 1675-1688.

Ruffet, G., Féraud, G., Ballèvre, M., Kiénast, J.R., 1995. Plateau ages and excess argon on phengites: a ${ }^{40} \mathrm{Ar} /{ }^{39} \mathrm{Ar}$ laser probe study of alpine micas (Sesia zone). Chemical Geology, 121(11), 327-343.

Ruppel, C., Royden, L., Hodges, K.V., 1988. Thermal modeling of extensional tectonics: application to pressure-temperature-time histories of metamorphic rocks. Tectonics, 7(5), 947-957.

Schaubs, P.M., Carr, S.D., Berman, R.G., 2002. Structural and metamorphic constraints on ca. 70Ma deformation of the northern Valhalla complex, British Columbia: implications for the tectonic evolution of the southern Omineca belt. Journal of structural geology, 24(6), 1195-1214.

Schrijver, K., 1973. Correlated changes in mineral assemblages and in rock habit and fabric across an orthopyroxene isograd, Grenville Province, Quebec. American Journal of Science, 273(2), 171-186.

Schwerdtner, W.M., Rivers, T., Zeeman, B., Wang, C.C., Tsolas, J., Yang, J., Ahmed, M. 2014. Postconvergent structures in lower parts of the 1090-1050 Ma (early-Ottawan) thrust-sheet stack, Grenville Province of Ontario, southern Canadian Shield. Canadian Journal of Earth Sciences, 51(3), 243-265. 
Sláma, J., Košler, J, Condon, D.J., Crowley, J.L., Gerdes, A., Hanchar, J.M., Horstwood, M.S.A., Morris, G.A., Nasdala, L., Norberg, N., Schaltegger, U., Schoene, B., Tubrett, M.N., Whitehouse, M.J., 2008. Plešovice zircon - A new natural reference material for $\mathrm{U}-\mathrm{Pb}$ and $\mathrm{Hf}$ isotopic microanalysis. Chemical Geology, 249(1), 1-35.

Snoke, A.W., Tullis, J., Todd, V.R., 1998. Fault-related Rocks: A Photographic Atlas. Princeton: Princeton University Press, $613 \mathrm{pp}$.

Spear, F.S., 1993. Metamorphic phase equilibria and pressure-temperature-time paths. Washington, D.C.: Mineralogical Society of America, 799 pp.

Spear, F.S., 2004. Fast cooling and exhumation of the Valhalla metamorphic core complex, southeastern British Columbia. International Geology Review, 46(3), 193-209.

Spear, F.S., Florence, F.P., 1992. Thermobarometry in granulites: pitfalls and new approaches. Precambrian Research, 55(1), 209-241.

Spear, F.S., Kohn, M.J., Cheney, J.T., 1999. P-T paths from anatectic pelites. Contributions to Mineralogy and Petrology, 134(1), 17-32.

Spear, F.S., Parrish, R.R., 1996. Petrology and cooling rates of the Valhalla Complex, British Columbia, Canada. Journal of Petrology, 37(4), 733-765.

Storm, L.C., Spear, F.S., 2005. Pressure, temperature and cooling rates of granulite facies migmatitic pelites from the southern Adirondack Highlands, New York. Journal of Metamorphic Geology, 23(2), 107-130.

Sullivan, W. A., \& Snoke, A. W., 2007. Comparative anatomy of core-complex development in the northeastern Great Basin, USA. Rocky Mountain Geology, 42(1), 1-29.

Teyssier, C., Whitney, D.L., 2002. Gneiss domes and orogeny. Geology, 30(12), 1139-1142.

Tirel, C., 2004. Dynamique de l'extension des domaines continentaux épaissis: dômes métamorphiques et écoulement de la croûte ductile (Ph.D. thesis). Université de Rennes, Rennes, France, 252 pp.

Tirel, C., Brun, J.P., Burov, E., 2004. Thermomechanical modeling of extensional gneiss domes. Geological Society of America Special Papers, 380, 67-78.

Tirel, C., Brun, J.P., Burov, E., 2008. Dynamics and structural development of metamorphic core complexes. Journal of Geophysical Research: Solid Earth, 113(B04403), 1-25.

Tirel, C., Brun, J.P., Sokoutis, D., 2006. Extension of thickened and hot lithospheres: Inferences from laboratory modeling. Tectonics, 25(1), TC1005.

Tracy, R.J., 1982. Compositional zoning and inclusions in metamorphic minerals. Reviews in Mineralogy and Geochemistry, 10(1), 355-397.

Tracy, R.J., Robinson, P., Thompson, A.B., 1976. Garnet composition and zoning in the determination of temperature and pressure of metamorphism, central Massachusetts. American Mineralogist, 61, 762-775.

Turner, G., Huneke, J.C., Podosek, F.A., Wasserburg G.J., 1971. ${ }^{40} \mathrm{Ar} /{ }^{39} \mathrm{Ar}$ ages and cosmic ray exposure age of Apollo 14 samples. Earth and Planetary Science Letters, 12(1), 19-35.

Van Gool, J.A.M., Rivers, T., Calon, T., 2008. Grenville Front zone, Gagnon terrane, southwestern Labrador: Configuration of a midcrustal foreland fold-thrust belt. Tectonics, 27(1), TC1104.

Vanderhaeghe, O., Medvedev, S., Fullsack, P., Beaumont, C., Jamieson, R.A., 2003. Evolution of orogenic wedges and continental plateaux: insights from crustal thermal-mechanical models overlying subducting mantle lithosphere. Geophysical Journal International, 153(1), 27-51. 
Vielzeuf, D., Schmidt, M.W., 2001. Melting relations in hydrous systems revisited: application to metapelites, metagreywackes and metabasalts. Contributions to Mineralogy and Petrology, 141(3), 251-267.

Villa, I.M., 1998. Isotopic closure. Terra Nova, 10(1), 42-47.

Villa, I.M., Grobéty, B., Kelley, S.P., Trigila, R., Wieler, R., 1996. Assessing Ar transport paths and mechanisms for McClure Mountains Hornblende. Contribution to Mineralogy and Petrolology, 126(12), 67-80.

Villa, I.M., Puxeddu, M., 1994. Geochronology of the Larderello geothermal field: new data and the "closure temperature" issue. Contributions to Mineralogy and Petrology, 115(4), 415-426.

Watson, E.B., Harrison, T.M., 2005. Zircon thermometer reveals minimum melting conditions on earliest Earth. Science, 308(5723), 841-844.

Watson, E.B., Wark D.A., Thomas J.B., 2006. Crystallization thermometers for zircon and rutile. Contribution to Mineralogy and Petrolology, 151(4), 413-433.

Wernicke, B., 1985. Uniform-sense normal simple shear of the continental lithosphere. Canadian Journal of Earth Sciences, 22(1), 108-125.

Winter, J.D., 2001. An introduction to igneous and metamorphic petrology. New York: Prentice Hall, 699 pp.

Worley, B., Powell, R. 2000. High-precision relative thermobarometry: theory and a worked example. Journal of Metamorphic Geology, 18(1), 91-102.

Yardley, B.W.D., 1977. An empirical study of diffusion in garnet. American Mineralogist, 62, 793-800.

York, D., 1968. Least squares fitting of a straight line with correlated errors. Earth and planetary science letters, 5, 320-324.

\section{Figure Captions}

Fig. 1. Simplified geologic map of the Mauricie area (modified from Nadeau and Brouillette, 1995).

Age constraints on the Tawachiche and western Taureau shear zones are from Corrigan and van Breemen (1997) and Martignole and Friedman (1998). Opx-in isograd was drawn after Schriver (1973), and Hocq and Dufour $(1999,2002)$ following the descriptive definition of Carmichael (1978). Black rectangle represents study area shown on Fig. 2. Inset shows the simplified tectonic subdivisions of the Grenville Province (modified from Rivers, 2008) with the location of the Mauricie area (black rectangle). MT-Morin terrane, MTD-Mékinac-Taureau domain, SD-Shawinigan domain, PMD-PortneufMauricie domain, PLD-Parc des Laurentides domain, MA-Anorthosite, SMF-St. Maurice fault.

Fig. 2. Simplified geologic map of the study area with location of samples used for thermobarometry, U-Pb geochronology and ${ }^{40} \mathrm{Ar} /{ }^{39} \mathrm{Ar}$ thermochronology. Structural data (poles to foliation (circles) and lineations (X)) are divided according to structural domains delimited by dashed 
lines. Stereonets are lower hemisphere equal area projections. Contours were produced with Stereonet software v.1.5 using the $1 \%$ area method and 2 sigma contour intervals ( $2-20$ sigma) for stereonets containing more than 40 data points. Geologic map from Nadeau et al. 2009.

Fig. 3A. Panoramic view of the St-Tite gravel pit, a key outcrop where the eastern Taureau shear zone is best exposed and where samples RS11-098, RS11-089 and RS11-082 were collected. The inset is a sketch of the principal structures of the outcrop. Blue lines represent strongly deformed marble layers. Prime locations for the observation of top-down-to-the-ESE kinematic indicators are shown in red $(\sigma-$ and $\delta$-porphyroclasts, asymmetric z-folds). Letters in the inset refer to the locations of close-up photographs, which have the same orientation unless specified otherwise. Lineation $\left(L_{n+1}\right)$ is plunging to the ESE (see structural subdomain 3 on Fig. 2), i.e. subparallel to the outcrop surface. B. Lower strain area indicated by the preservation of an earlier, folded, foliation $S_{n}$ that is not completely transposed into the $S_{n+1}$ foliation. C. $\delta$-porphyroclast of orthopyroxene. D. $\sigma$-porphyroclast of K-feldspar-rich leucosome pod. E. Foliation $S_{n+1}$ of the host gneiss $(H)$ entrained at the margins of an anastomosing marble layer (M).

Fig. 4. A. Composite microphotograph in cross polarized light (XPL) of a paragneiss located in the Mékinac-Taureau domain $\sim 3 \mathrm{~km}$ below the eastern Taureau shear zone (sample RS11-058). Synkinematic recrystallization of quartz ribbons forming an oblique grain-shape fabric suggests top-downto-the-ESE sense of shear. Fine grain material within the quartz layer is a mixture of $\mathrm{Sil}+\mathrm{Bt}+\mathrm{Kfs}+\mathrm{PI}+$ Rt. B. Extensional ductile-brittle structure in the Shawinigan domain showing top-down-to-the-SE sense of shear. View is not perfectly parallel to the stretching lineation along the shear plane, which plunges towards the SE. These structures are interpreted as structurally higher equivalents of the Taureau shear zone that were active during waning stages of extension.

Fig. 5. Representative microphotographs of metapelite and amphibolite analyzed for thermobarometry. A. Typical metamorphic assemblage in metapelite RS11-105 of the Shawinigan domain containing $\mathrm{Qtz}+\mathrm{Kfs}+\mathrm{Pl}+\mathrm{Grt}+\mathrm{Bt}+\mathrm{Sil}$. This assemblage characterizes all metapelites from the Mauricie area. B. Perfectly euhedral garnet grains from the interior of the Mékinac-Taureau domain (sample RS11-021). C. Type 1 garnet containing abundant ilmenite inclusions (sample RS11-105). D. Type 2 garnet containing abundant quartz inclusions (sample RS11-105). E. Type 3 inclusion-poor garnet (sample RS11-105). F. View parallel to the lineation of an amphibolite with $\sigma$-shaped reaction rims of 
NOTICE: this is the author's version of a work that was accepted for publication in Precambrian Research. Changes resulting from the publishing process, such as peer review, editing, corrections, structural formatting, and other quality control mechanisms may not be reflected in this document. Changes may have been made to this work since it was submitted for publication. A definitive version was subsequently published in Precambrian Research, 257, (Feb 2015). doi: 10.1016/j.precamres.2014.11.012

plagioclase and hornblende around garnet (sample RS11-082B). Inset is a view perpendicular to the lineation at the same scale. Sigmoid shape of reaction rims implies that the reaction was pre- to synkinematic.

Fig. 6. Representative chemical composition profiles of garnet from core to rim. A Metapelite from the interior of the Mékinac-Taureau domain. B-C. Metapelite from the external zone of the Mékinac-Taureau domain. D-G. Metapelite from the Shawinigan domain. H. Amphibolite from the eastern Taureau shear zone. Notice the lack of zoning in garnet typical of retrograde net transfer reaction in migmatitic metapelites, such as spike in $X_{\text {sps }}$ at the rim (Spear et al. 1999). See text for additional interpretation of the zonation.

Fig. 7. Pressure and temperature obtained from the Mékinac-Taureau and the Shawinigan domain with metapelites (A) and amphibolite (B). Samples are located on Fig. 2. Uncertainties for the metapelites are $\pm 50{ }^{\circ} \mathrm{C}$ and $\pm 100 \mathrm{MPa}$ on temperature and pressure, respectively, as estimated by Essene (1989) and Berman (1991), and are represented by parallelograms based on the thermometric and barometric reactions. The amphibolite was used to calculate peak and retrograde conditions by combining all possible permutations of the mineral compositions data set. Pink stars show the averages of all permutations with a 95\% confidence ellipse. Note that these errors do not include uncertainties stemming from the thermodynamic database nor from calculations of mineral activities. Results suggest high grade (820-880 ${ }^{\circ} \mathrm{C}$; $\left.1000-100 \mathrm{MPa}\right)$ metamorphism in the Mékinac-Taureau domain overprinted by retrograde metamorphism $\left(675-775{ }^{\circ} \mathrm{C} ; 650-800 \mathrm{MPa}\right)$ in the upper structural levels, whereas the Shawinigan domain was metamorphosed at conditions varying from 775 to $700{ }^{\circ} \mathrm{C}$ and from 850 to 625 MPa. See text for further explications. Ky-Sil transition is from Pattison (1992); wet solidus and Ms-out reaction are from Vielzeuf and Schmidt (2001) and references therein; compositional dependant Bt-out reactions are from phase equilibria modeling of a typical metapelite (Brown, 2010; B10) and from the partial melting experiment of a two-micas pelite (Patino Douce and Johnson, 1991; PDJ91). The prograde equivalent of the net transfer reaction (7), Bt $+\mathrm{Sil}+\mathrm{Pl}+\mathrm{Qtz}=\mathrm{Grt}+\mathrm{Kfs}+$ melt, operates once the Ms-out reaction is crossed and as long as all reactants are present in the rock (i.e. until the Bt-out reaction).

Fig. 8. Syn-kinematic pegmatite (sample RS11-098) cross-cutting the host rock foliation, but locally containing a weak internal foliation parallel to the external foliation $S_{n+1}$. "C-S" fabric above the main 
NOTICE: this is the author's version of a work that was accepted for publication in Precambrian Research. Changes resulting from the publishing process, such as peer review, editing, corrections, structural formatting, and other quality control mechanisms may not be reflected in this document. Changes may have been made to this work since it was submitted for publication. A definitive version was subsequently published in Precambrian Research, 257, (Feb 2015). doi: 10.1016/j.precamres.2014.11.012

pod (Fig. 8B) and dragging of the host gneiss foliation indicate top-down-to-the-ESE sense of shear. Rectangle shows the location of Fig. 8B. Inset outlines the major contacts between the pegmatite and the host rock. B. C-S fabric indicating syn-kinematic emplacement of the pegmatite. S-planes are defined by the host rock foliation and pegmatite dykelets define C-planes. Also note the $\sigma$-porphyroclast (P) of clinopyroxene partially replaced by hornblende, indicating retrograde metamorphism prior to or during shearing.

Fig. 9. A. Cathodoluminescence images of representative zircon from sample RS11-098. Group 1 zircon is commonly overgrown by Group 2 and rarely by Group 3 zircon, but no physical relationship is observed between Groups 2 and 3. Group 1 zircon is interpreted as primary igneous zircon, Groups 2 and 3 as metamorphic zircon, and Group 4 as inherited zircon. Circles are spots analyzed for geochronology. Their diameters are $25 \mu \mathrm{m}$ large except for spots outlined in white, which are $30 \mu \mathrm{m}$. B. Cathodoluminescence images of representative zircon crystals from sample RS12-040. Prismatic shape and oscillatory zoning of zircon from this sample are typical of igneous crystallization. Analyzed spots are $25 \mu \mathrm{m}$ large.

Fig. 10. A-D. Geochemical composition diagrams showing differences and similarities between Groups 1-4 zircon from sample RS11-098. Similar chemical composition between Groups 1 and 2 and depletion of non-essential structural constituent cations (ex: $U, T$ Th, REE) in Group 2 as compared to Group 1, suggest that Group 2 zircon is derived from dissolution and reprecipitation of Group 1 zircon (Hoskin and Black, 2000; Hoskin and Schaltegger, 2003). Group 3 zircon has a distinct chemical composition that suggests an origin from a distinct fluid. Group 4 zircon includes inherited cores that do not match the composition and/or age of Group 1-3 zircon. See text for details.

Fig. 11. Weighted mean 207Pb/206Pb dates for A-C. syn-extension pegmatite RS11-098 (UTM 680719E, 5178838N, NAD 83, zone 18N) and D. post metamorphic peak pegmatite RS12-040 (UTM $674542 \mathrm{E}, 5172883 \mathrm{~N}, \mathrm{NAD} 83$, zone $18 \mathrm{~N})$. Error on individual dates are given at $2 \sigma$ and do not include the standard calibration uncertainty. Error on weighted mean (grey boxes) are given at $2 \sigma$ upon propagation of the standard calibration uncertainties. Weighted mean $207 \mathrm{~Pb} / 206 \mathrm{~Pb}$ dates are preferred for interpretations because they are more precise than $\mathrm{U} / \mathrm{Pb}$ dates upon propagation of standard calibration uncertainties and because they are not affected by recent $\mathrm{Pb}$ loss. MSWD-mean square weighted deviation, PF-probability of fit, $n$-number of analyses, Ti-in-Zrn-Temperature of 
crystallization based on the Ti-in-zircon thermometer (Ferry and Watson, 2007; Watson et al. 2006). Isotope ratios, ages, chemical composition and temperature of crystallization for any single analysis can be found in supplementary data table 2 .

Fig. 12. ${ }^{39} \mathrm{Ar} /{ }^{40} \mathrm{Ar}$ age spectra for A. amphibole and biotite of sample RS11-002; B. amphibole and biotite of sample RS11-115; C. biotite of sample RS11-015; D. amphibole of sample RS11-089; E. amphibole and biotite of sample RS11-113; F. biotite of sample RS11-105. The age error bars for each temperature steps are at the $1 \sigma$ level. Plateau and pseudo-plateau ages (2 $\sigma$ uncertainties) are given when applicable. See text for interpretations. Samples are located on Fig. 2.

Fig. 13. Compilation of thermobarometric, thermochronologic and geochronologic results placed on a schematic cross-section of the southeastern Mékinac-Taureau and Shawinigan domains. Samples are located on Fig. 2 and their structural positions (in $\mathrm{km}$ ) is projected perpendicular to the eastern Taureau shear zone.. ${ }^{40} \mathrm{Ar} /{ }^{39} \mathrm{Ar}$ cooling ages are defined by plateau ages, except for sample RS11-113 ( $\mathrm{Hbl}$ ) that is defined by a pseudo-plateau. U-Pb dates $\left({ }^{207} \mathrm{~Pb} /{ }^{206} \mathrm{~Pb}\right.$ on zircon) provide a minimum age for regional deformation and peak metamorphism (RS12-040) and an age of significant shearing along the eastern Taureau shear zone (RS11-098). See text for further details and interpretation.

Fig. 14. A. Simplified geologic map of lithotectonic domains and major shear zones of the Mauricie area (modified from Nadeau and Brouillette, 1995). Cross section A-A' is shown in Fig. 14C. B. Schematic structural profile representing the configuration of thrust-imbricated domains prior to extension. This configuration might have prevailed before $1082 \pm 20 \mathrm{Ma}$, the minimal age constraint determined for peak metamorphism and thrusting in the Mékinac-Taureau domain. The vertical pressure scale is based on values obtained from the Mékinac-Taureau and Shawinigan domains and depth in kilometers is calculated assuming a pressure gradient of $30 \mathrm{MPa} / \mathrm{km}$ (Winter, 2001). Red pods represent leucosome material at the Mékinac-Taureau and Shawinigan domains interface. The approximate trace of the future detachment zone (i.e. the eastern Taureau and Tawachiche shear zones) is shown on the crosssection. C. A-A' cross-section showing the architecture after the 1065-1035 Ma episode of extension, modified after Rivers (2012) and Rivers et al. (2012). Deformation was localized along both the eastern Taureau and Tawachiche shear zones, responsible for the exhumation of the Mékinac-Taureau and Shawinigan domains as a metamorphic core complex. Reference points (blue stars) show how different crustal levels were juxtaposed laterally. WTSZ-western Taureau shear zone, ETSZ-eastern Taureau 
shear zone, TWSZ-Tawachiche shear zone.

\section{Table captions}

Table 1. Summary of chemical compositions from microprobe analyses and calculated P-T results.

Table 2. Summary of ${ }^{40} \mathrm{Ar} /{ }^{39} \mathrm{Ar}$ results.

\section{Supplementary data repository captions}

Supplementary U-Pb and ${ }^{40} \mathrm{Ar} /{ }^{39} \mathrm{Ar}$ geochronology analytical methods.

Supplementary data table 1 . Mineral compositions determined by electron microprobe analysis.

Supplementary data table 2. U-Pb isotopic compositions and trace element concentrations.

Supplementary data table $2 .{ }^{40} \mathrm{Ar} /{ }^{39} \mathrm{Ar}$ data.

Supplementary Fig. S1. Concordia diagrams for Groups 1-3 zircon of pegmatite RS11-098. D. Concordia diagram for zircon of pegmatite RS12-040. Individual error ellipses are at $2 \sigma$ level and do not include standard calibration uncertainties. Dates are ${ }^{207} \mathrm{~Pb} /{ }^{206} \mathrm{~Pb}$ weighted averages and errors are at $2 \sigma$ level, including standard calibration uncertainties. 
NOTICE: this is the author's version of a work that was accepted for publication in Precambrian Research. Changes resulting from the publishing process, such as peer review, editing, corrections, structural formatting, and other quality control mechanisms may not be reflected in this document. Changes may have been made to this work since it was submitted for publication. A definitive version was subsequently published in Precambrian Research, 257, (Feb 2015). doi: 10.1016/j.precamres.2014.11.012

1 We conducted thermobarometry and geochronology on samples of the Mauricie area.

2 Peak metamorphism ( $1000-1100 \mathrm{MPa}$ and $\sim 820-880^{\circ} \mathrm{C}$ ) occurred prior to $1082 \pm 20 \mathrm{Ma}$.

3 A top-down-to-the-ESE shear zone is responsible for exhumation at 1064 \pm 15 Ma.

$4 \quad$ Shearing was coeval with retrograde metamorphism.

5 A metamorphic core complex was formed by orogenic collapse in fixed-boundary mode. 


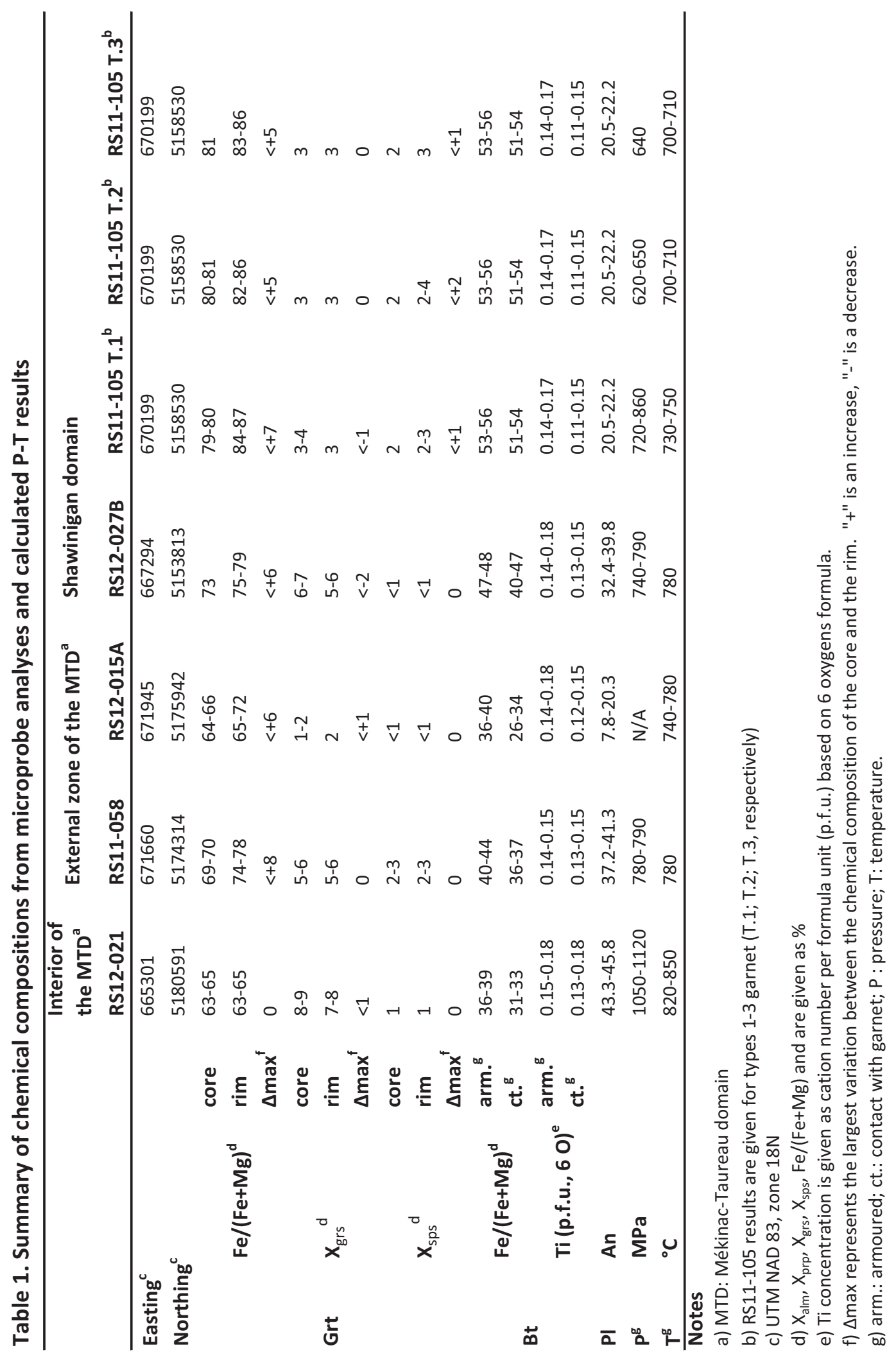


NOTICE: this is the author's version of a work that was accepted for publication in Precambrian Research. Changes resulting from the publishing process, such as peer review, editing, corrections, structural formatting, and other quality control mechanisms may not be reflected in this document. Changes may have been made to this work since it was submitted for publication. A definitive version was subsequently published in Precambrian Research, 257, (Feb 2015). doi: 10.1016/j.precamres.2014.11.012

Table 1. Continued

\begin{tabular}{|c|c|c|c|}
\hline & & & $\begin{array}{l}\text { Eastern Taureau } \\
\text { shear zone } \\
\text { RS11-082B }\end{array}$ \\
\hline \multicolumn{3}{|c|}{ Easting $^{a}$} & 680747 \\
\hline \multicolumn{3}{|c|}{ Northing $^{a}$} & 5178829 \\
\hline & & core & $71-79$ \\
\hline & \multirow[t]{3}{*}{$\mathrm{Fe} /(\mathrm{Fe}+\mathrm{Mg})^{\mathrm{b}}$} & inner rim & $74-75$ \\
\hline & & outer rim & $74-76$ \\
\hline & & core & $18-30$ \\
\hline \multirow[t]{5}{*}{ Grt } & \multirow[t]{3}{*}{$X_{\text {grs }}{ }^{b}$} & inner rim & $27-32$ \\
\hline & & outer rim & $18-20$ \\
\hline & & core & $2-4$ \\
\hline & \multirow[t]{2}{*}{$\mathbf{X}_{\mathrm{sps}}^{\mathrm{b}}$} & inner rim & $2-3$ \\
\hline & & outer rim & $4-5$ \\
\hline \multirow{2}{*}{$\mathrm{Hbl}$} & \multirow{2}{*}{$\mathrm{Fe} /(\mathrm{Fe}+\mathrm{Mg})^{\mathrm{b}}$} & groundmass & $43-45$ \\
\hline & & reaction rim & $40-44$ \\
\hline \multirow{2}{*}{ PI } & \multirow{2}{*}{ An } & groundmass & $40.2-50.7$ \\
\hline & & reaction rim & $48.5-58.0$ \\
\hline \multirow{2}{*}{$\mathbf{P}^{c}$} & \multirow{2}{*}{$\mathrm{MPa}$} & peak $^{d}$ & 990 \\
\hline & & retro $^{d}$ & 650 \\
\hline \multirow{2}{*}{$T^{c}$} & \multirow{2}{*}{${ }^{\circ} \mathrm{C}$} & peak $^{d}$ & 880 \\
\hline & & retro $^{d}$ & 720 \\
\hline
\end{tabular}

Notes
a) UTM NAD 83, zone $18 \mathrm{~N}$
b) $X_{\text {alm }}, X_{\text {prp }}, X_{\text {grs }}, X_{\text {sps }}, \mathrm{Fe} /(\mathrm{Fe}+\mathrm{Mg}$ ) and are given as \%
c) T: temperature; $P$ : pressure
d) peak: metamorphic peak; retro: retrograde metamorphism 
NOTICE: this is the author's version of a work that was accepted for publication in Precambrian Research. Changes resulting from the publishing process, such as peer review, editing, corrections, structural formatting, and other quality control mechanisms may not be reflected in this document. Changes may have been made to this work since it was submitted for publication. A definitive version was subsequently published in Precambrian Research, 257, (Feb 2015). doi: 10.1016/j.precamres.2014.11.012

Table 2. Summary of ${ }^{40} \mathrm{Ar} /{ }^{39} \mathrm{Ar}$ results

\begin{tabular}{|c|c|c|c|c|c|c|}
\hline Sample & Easting $^{a}$ & Northing $^{\mathrm{a}}$ & $\begin{array}{l}\text { Mineral } \\
\text { dated }\end{array}$ & $\begin{array}{l}\text { Age }^{b} \\
(\mathrm{Ma})\end{array}$ & $\begin{array}{l} \pm 2 \sigma \\
(\mathrm{Ma})\end{array}$ & $\begin{array}{l}\%^{39} \mathrm{Ar}_{\mathrm{K}} \\
\text { defining } \\
\text { plateau }\end{array}$ \\
\hline \multicolumn{7}{|c|}{ Core of the Mékinac -Taureau domain (12 and $8 \mathrm{~km}$ below the ETSZ) } \\
\hline RS11-002 & 657793 & 5196510 & $\mathrm{Hbl}$ & 998.6 & 7.4 & 85.8 \\
\hline RS11-002 & 657793 & 5196510 & $\mathrm{Bt}$ & 923.2 & 7.0 & 96.5 \\
\hline RS11-115 & 666117 & 5191538 & $\mathrm{Hbl}$ & 1010.0 & 7.4 & 93.4 \\
\hline RS11-115 & 666117 & 5191538 & $\mathrm{Bt}$ & 969.8 & 7.2 & 74.8 \\
\hline \multicolumn{7}{|c|}{ External zone of the Mékinac-Taureau domain ( $3 \mathrm{~km}$ below the ETSZ) } \\
\hline RS11-015 & 671176 & 5177599 & $\mathrm{Bt}$ & 926.1 & 7.0 & 88.2 \\
\hline \multicolumn{7}{|c|}{ Eastern Taureau shear zone (within the ETSZ) } \\
\hline RS11-089 & 680697 & 5178880 & $\mathrm{Hbl}$ & 1031.6 & 7.6 & 86.4 \\
\hline \multicolumn{7}{|c|}{ Shawinigan domain ( 2 and $4 \mathrm{~km}$ above the ETSZ) } \\
\hline RS11-113 & 685301 & 5177182 & $\mathrm{Hbl}$ & 1022.3 & 7.6 & 49.2 \\
\hline RS11-113 & 685301 & 5177182 & Hbl (pert. ${ }^{c}$ ) & 1012.3 & 8.0 & 13.6 \\
\hline RS11-113 & 685301 & 5177182 & $\mathrm{Bt}$ & 930.4 & 7.0 & 79.3 \\
\hline RS11-105 & 670199 & 5158530 & Bt & 905.8 & 6.8 & 83.1 \\
\hline
\end{tabular}

Notes
a) UTM NAD 83, zone $18 \mathrm{~N}$
b) all dates are plateau ages except for RS11-113 $\mathrm{Hbl}$
c) pert. : thermal perturbation pseudo-plateau. 
NOTICE: this is the author's version of a work that was accepted for publication in Precambrian Research. Changes resulting from the publishing process, such as peer review, editing, corrections, structural formatting, and other quality control mechanisms may not be reflected in this document. Changes may have been made to this work since it was submitted for publication. A definitive version was subsequently published in Precambrian Research, 257, (Feb 2015). doi: 10.1016/j.precamres.2014.11.012
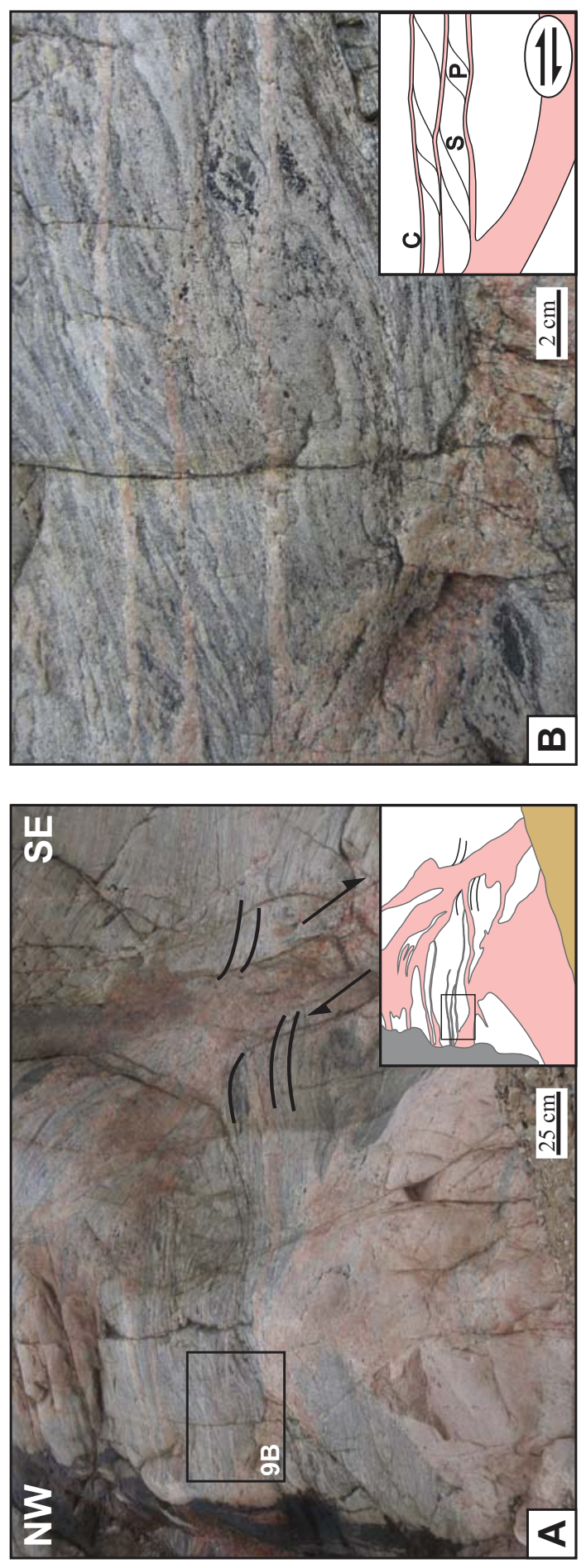
NOTICE: this is the author's version of a work that was accepted for publication in Precambrian Research. Changes resulting from the publishing process, such as peer review, editing, corrections, structural formatting, and other quality control mechanisms may not be reflected in this document. Changes may have been made to this work since it was submitted for publication. A definitive version was subsequently published in Precambrian Research, 257, (Feb 2015). doi: 10.1016/j.precamres.2014.11.012

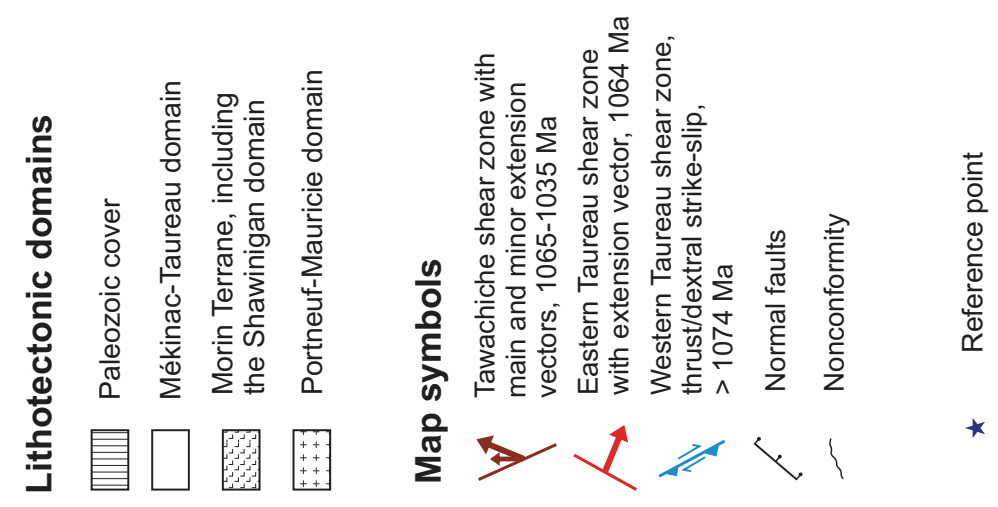

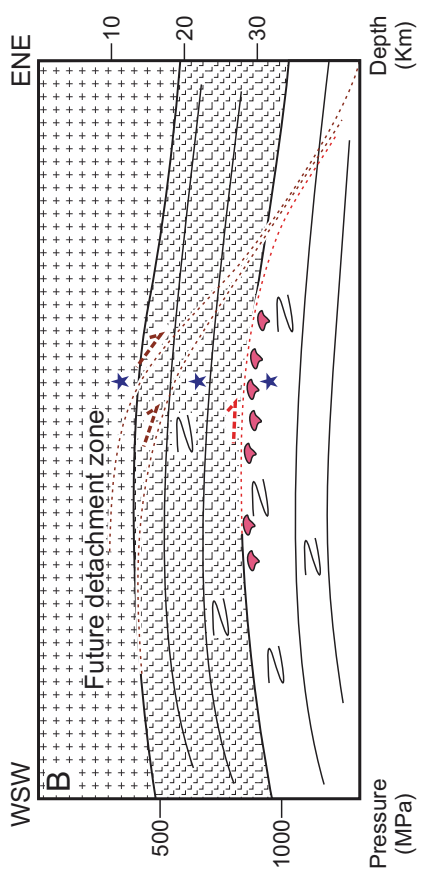

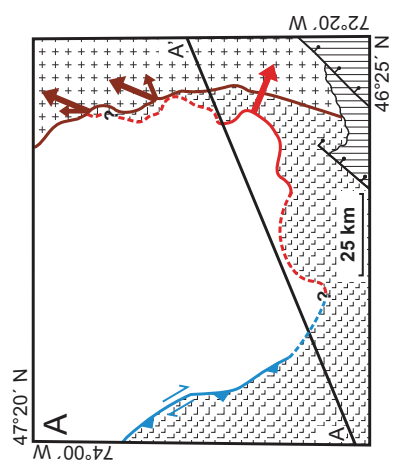

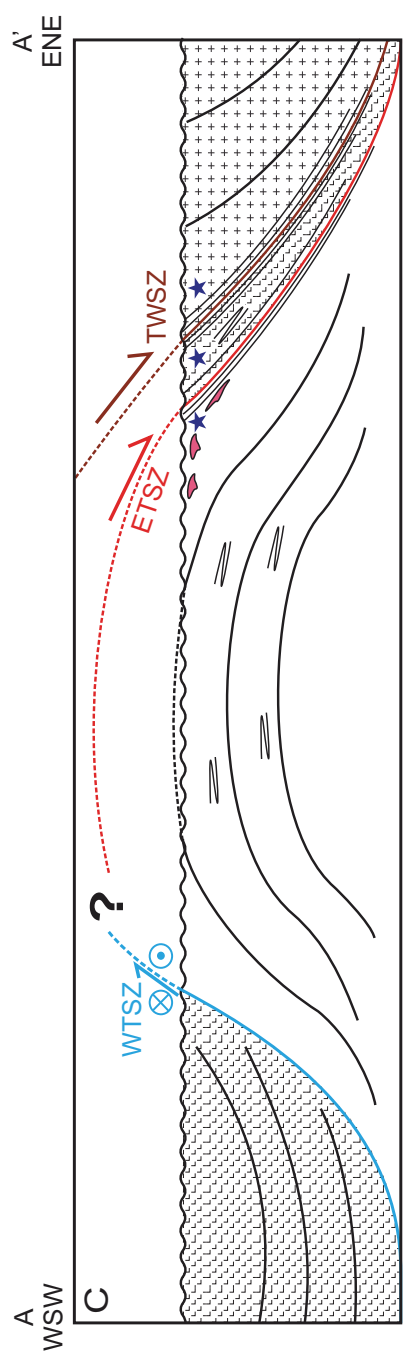

$\| 1 N$

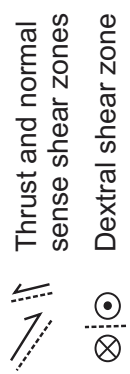


NOTICE: this is the author's version of a work that was accepted for publication in Precambrian Research. Changes resulting from the publishing process, such as peer review, editing, corrections, structural formatting, and other quality control mechanisms may not be reflected in this document. Changes may have been made to this work since it was submitted for publication. A definitive version was subsequently published in Precambrian Research, 257, (Feb 2015). doi: 10.1016/j.precamres.2014.11.012

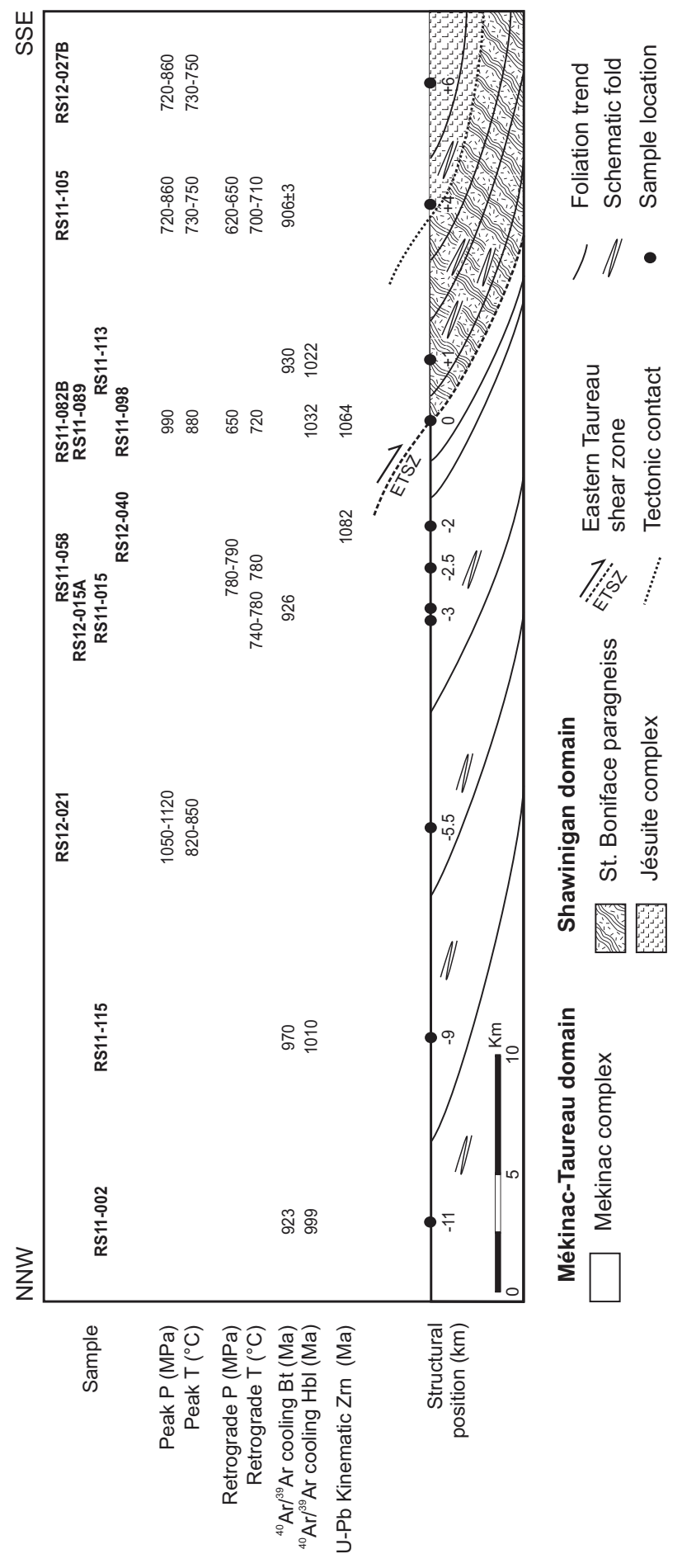


NOTICE: this is the author's version of a work that was accepted for publication in Precambrian Research. Changes resulting from the publishing process, such as peer review, editing, corrections, structural formatting, and other quality control mechanisms may not be reflected in this document. Changes may have been made to this work since it was submitted for publication. A definitive version was subsequently published in Precambrian Research, 257, (Feb 2015). doi: 10.1016/j.precamres.2014.11.012
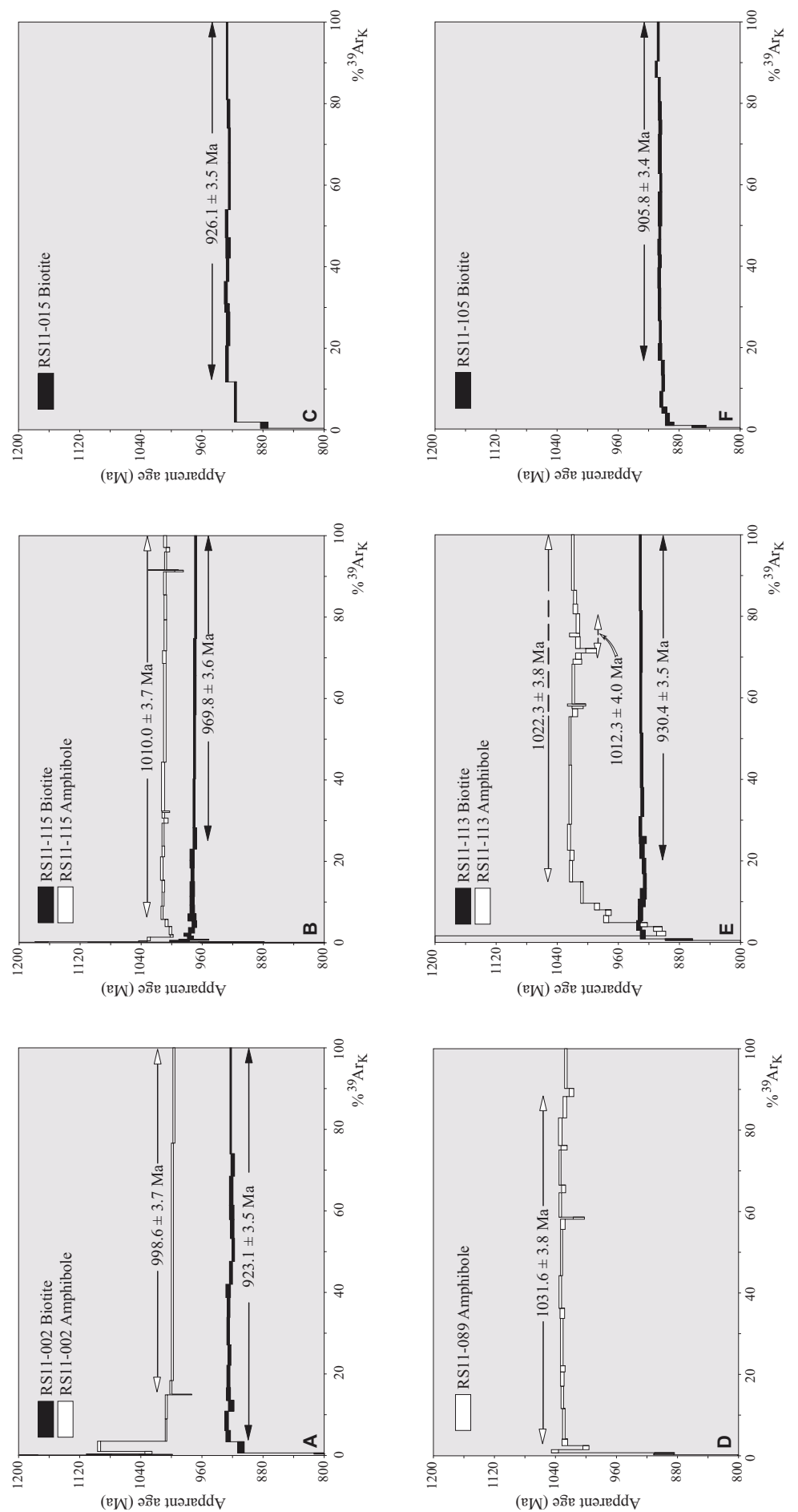

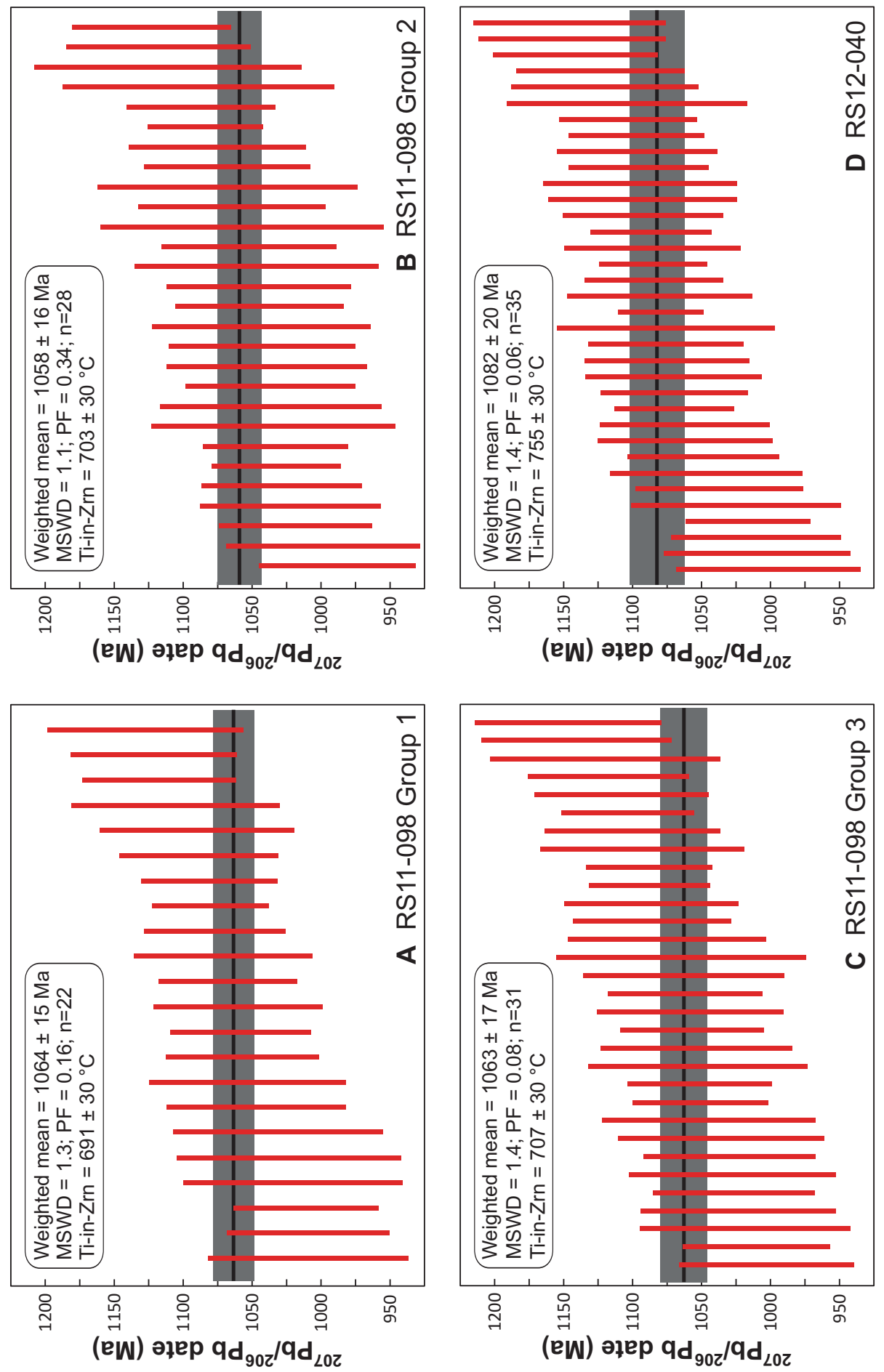
NOTICE: this is the author's version of a work that was accepted for publication in Precambrian Research. Changes resulting from the publishing process, such as peer review, editing, corrections, structural formatting, and other quality control mechanisms may not be reflected in this document. Changes may have been made to this work since it was submitted for publication. A definitive version was subsequently published in Precambrian Research, 257, (Feb 2015). doi: 10.1016/j.precamres.2014.11.012
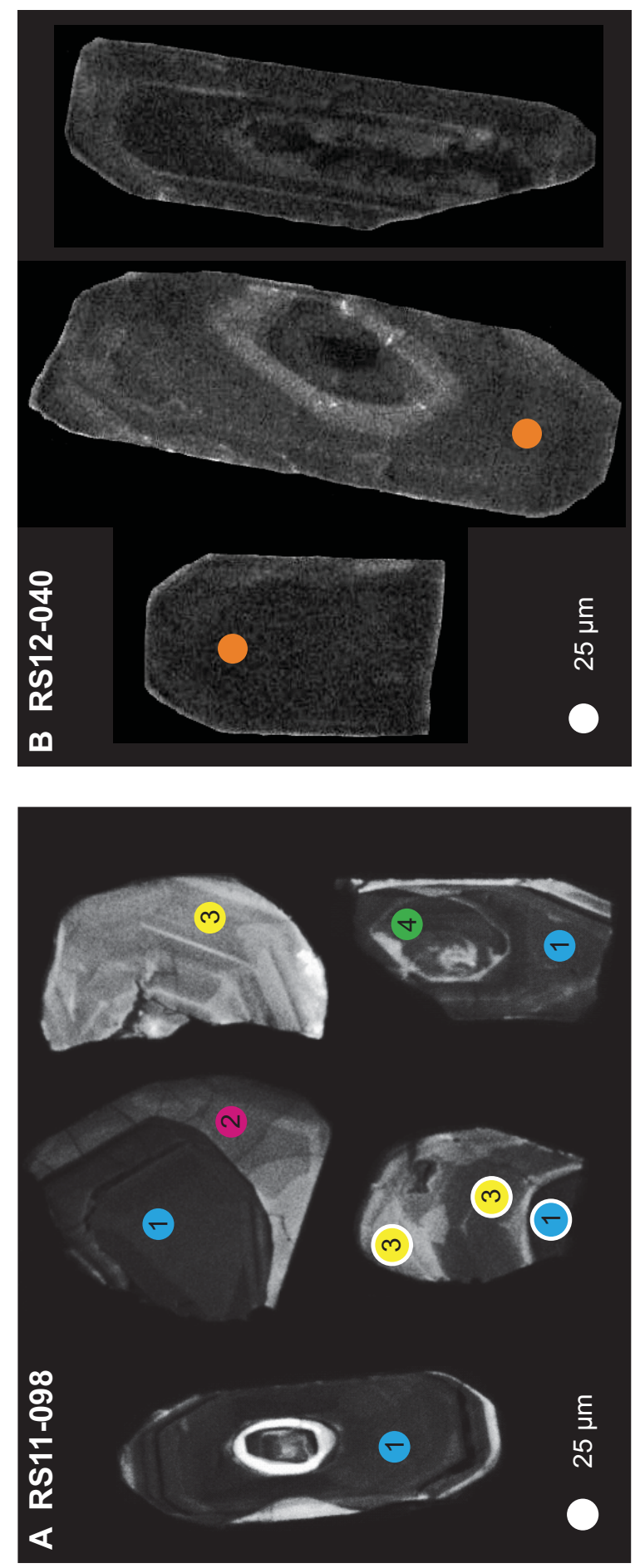
NOTICE: this is the author's version of a work that was accepted for publication in Precambrian Research. Changes resulting from the publishing process, such as peer review, editing, corrections, structural formatting, and other quality control mechanisms may not be reflected in this document. Changes may have been made to this work since it was submitted for publication. A definitive version was subsequently published in Precambrian Research, 257, (Feb 2015). doi: 10.1016/j.precamres.2014.11.012
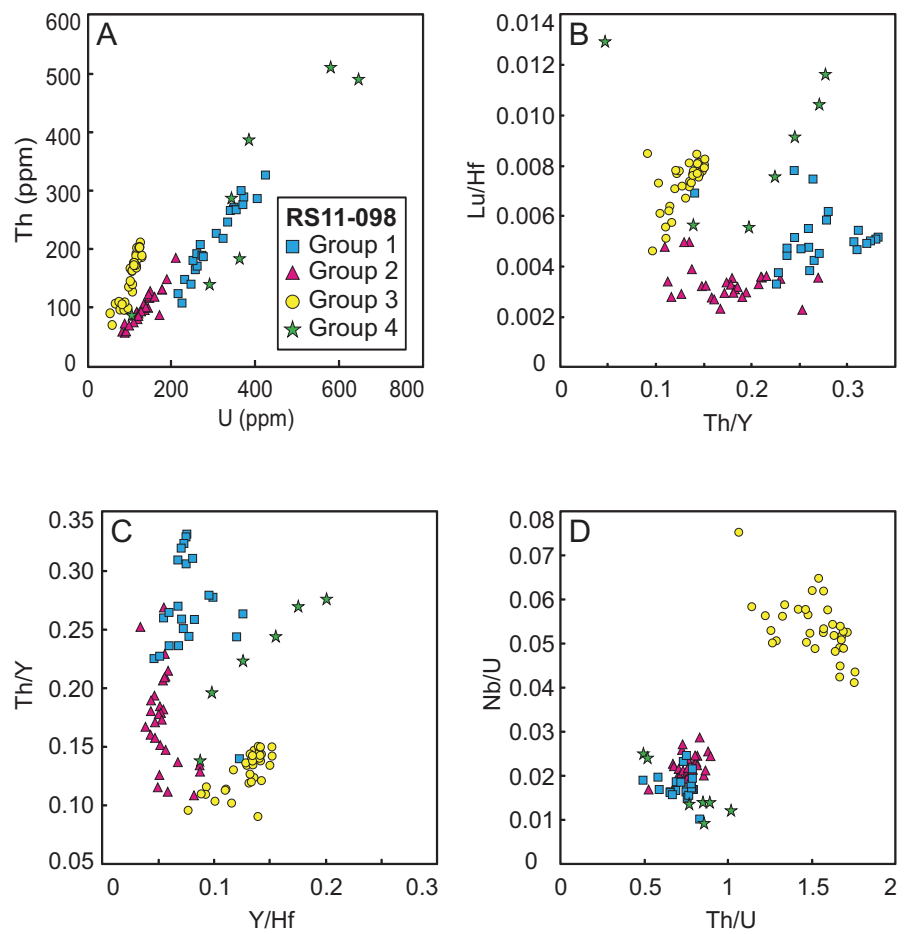
NOTICE: this is the author's version of a work that was accepted for publication in Precambrian Research. Changes resulting from the publishing process, such as peer review, editing, corrections, structural formatting, and other quality control mechanisms may not be reflected in this document. Changes may have been made to this work since it was submitted for publication. A definitive version was subsequently published in Precambrian Research, 257, (Feb 2015). doi: 10.1016/j.precamres.2014.11.012
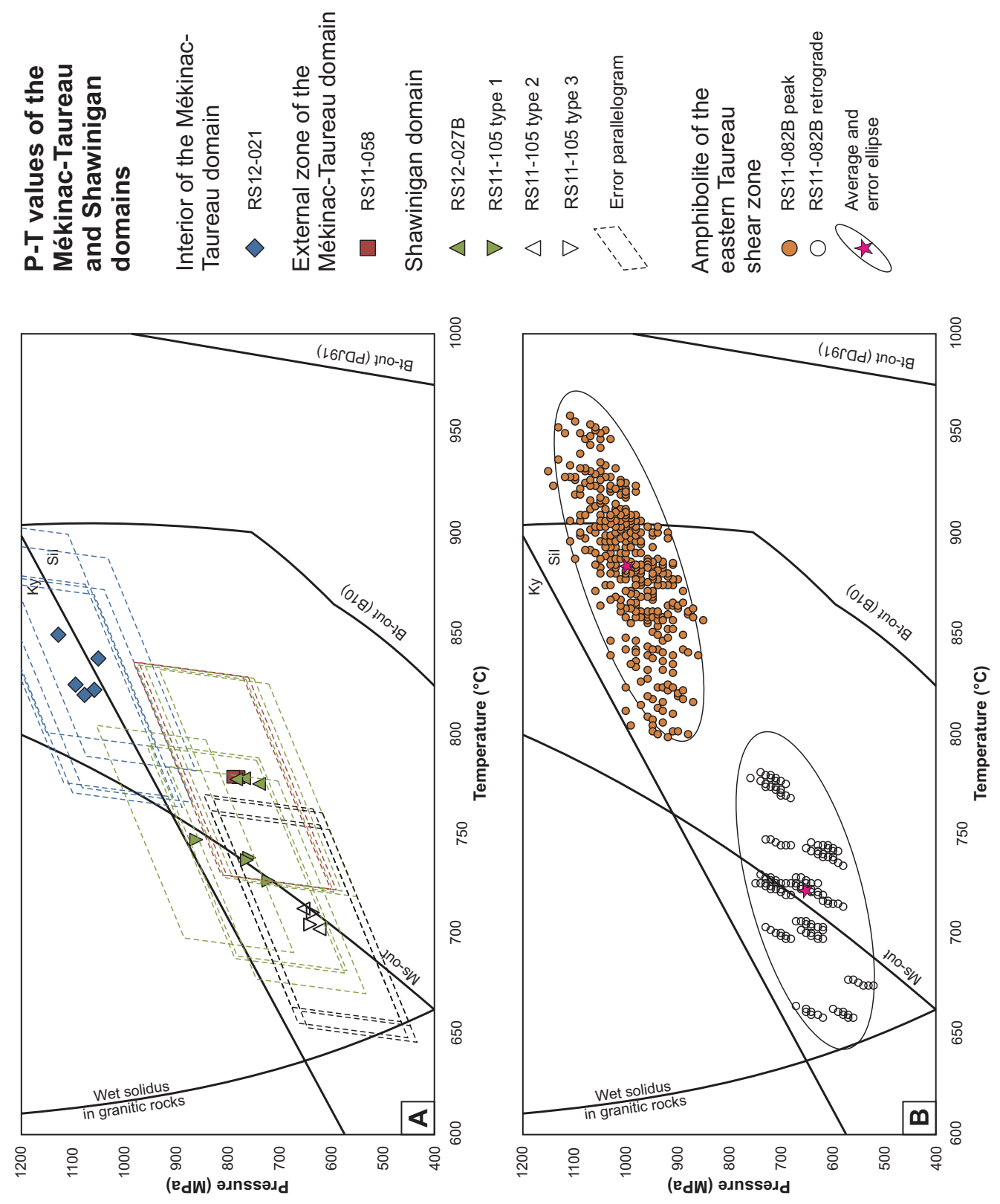

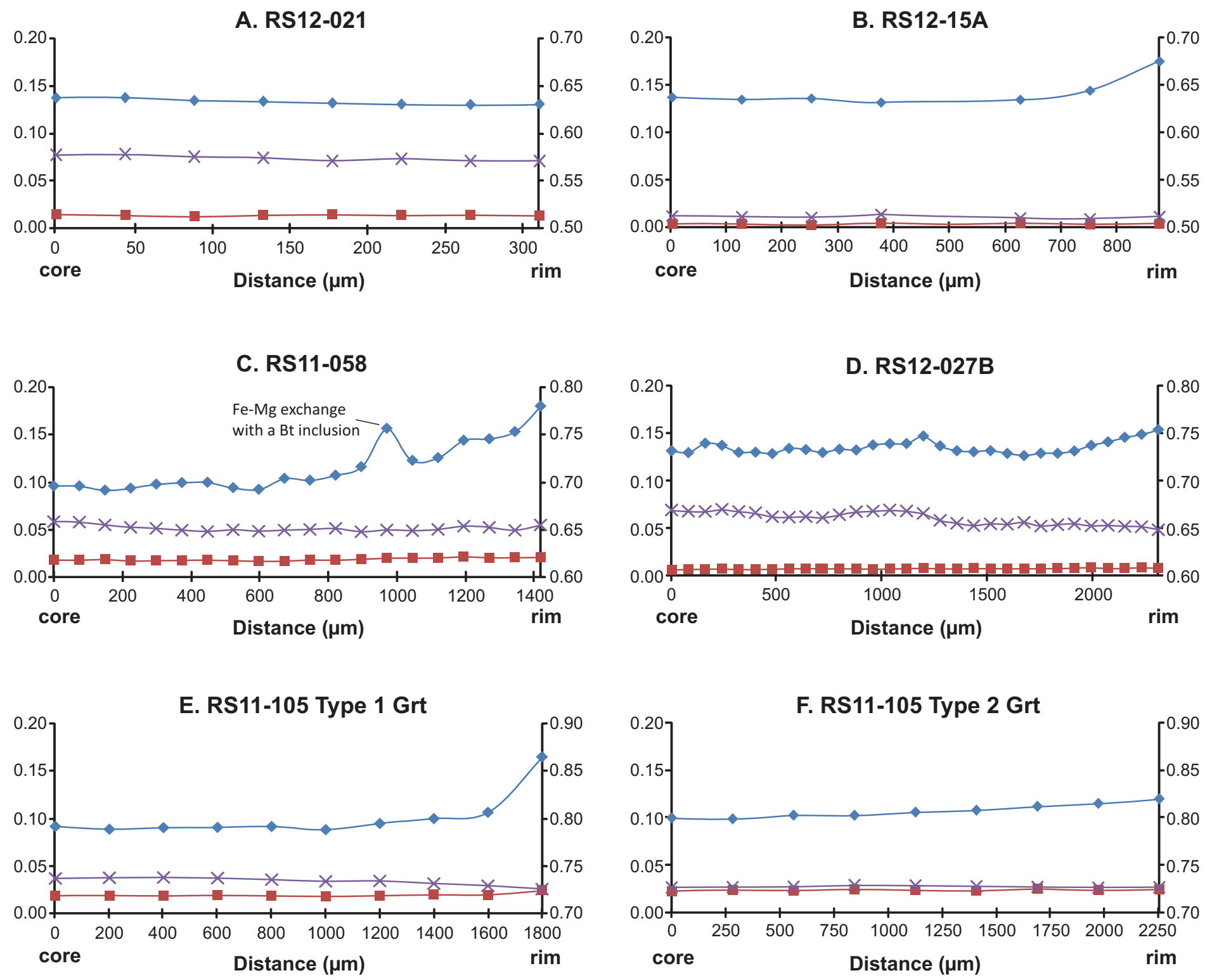

\section{G. RS11-105 Type 3 Grt}

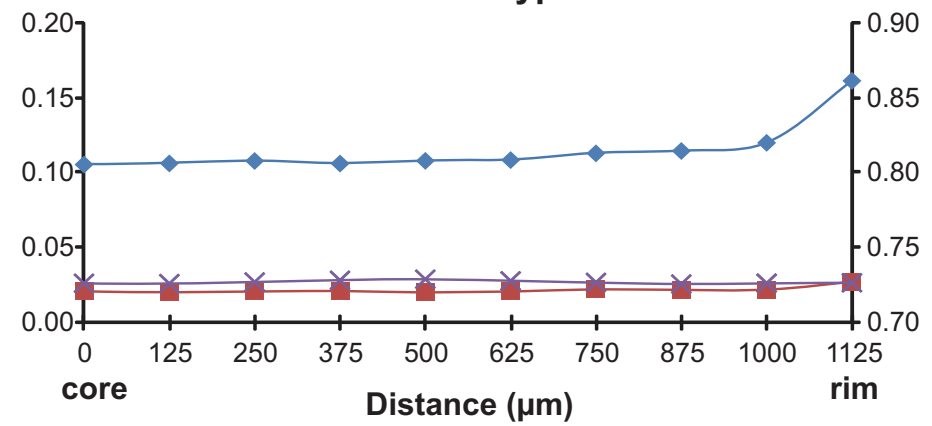

$\longrightarrow X_{\text {grs }}$
$-X_{\text {sps }}$
Distance $(\mu \mathrm{m})$

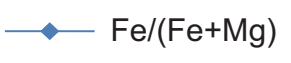

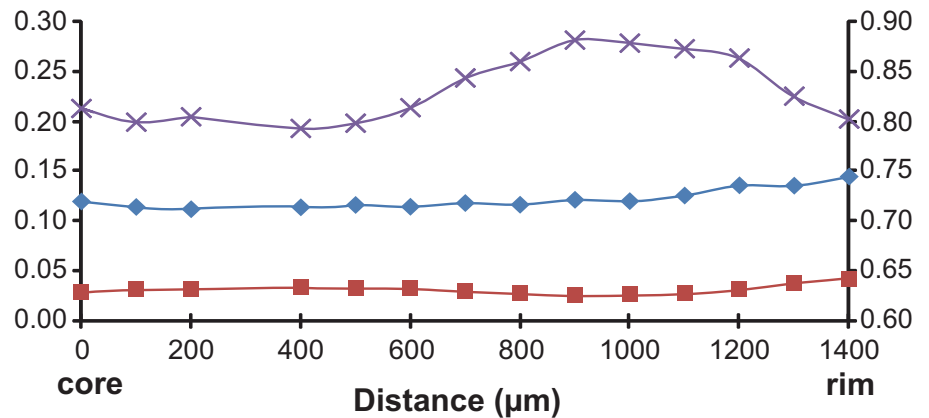

$x-X_{\text {grs }}$
$\longleftarrow-X_{\text {sps }}$ 
NOTICE: this is the author's version of a work that was accepted for publication in Precambrian Research. Changes resulting from the publishing process, such as peer review, editing, corrections, structural formatting, and other quality control mechanisms may not be reflected in this document. Changes may have been made to this work since it was submitted for publication. A definitive version was subsequently published in Precambrian Research, 257, (Feb 2015). doi: 10.1016/j.precamres.2014.11.012
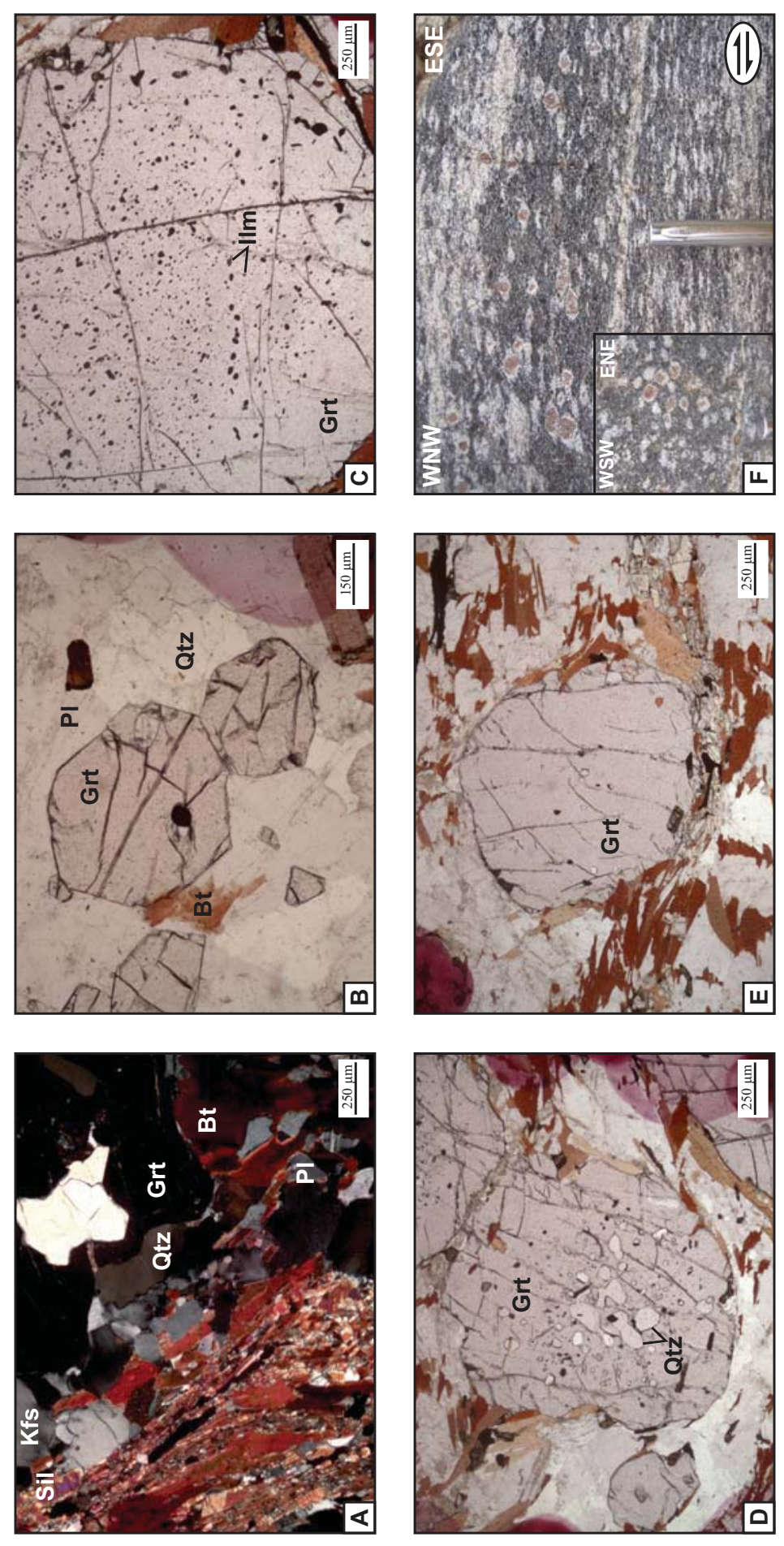
NOTICE: this is the author's version of a work that was accepted for publication in Precambrian Research. Changes resulting from the publishing process, such as peer review, editing, corrections, structural formatting, and other quality control mechanisms may not be reflected in this document. Changes may have been made to this work since it was submitted for publication. A definitive version was subsequently published in Precambrian Research, 257, (Feb 2015). doi: 10.1016/j.precamres.2014.11.012
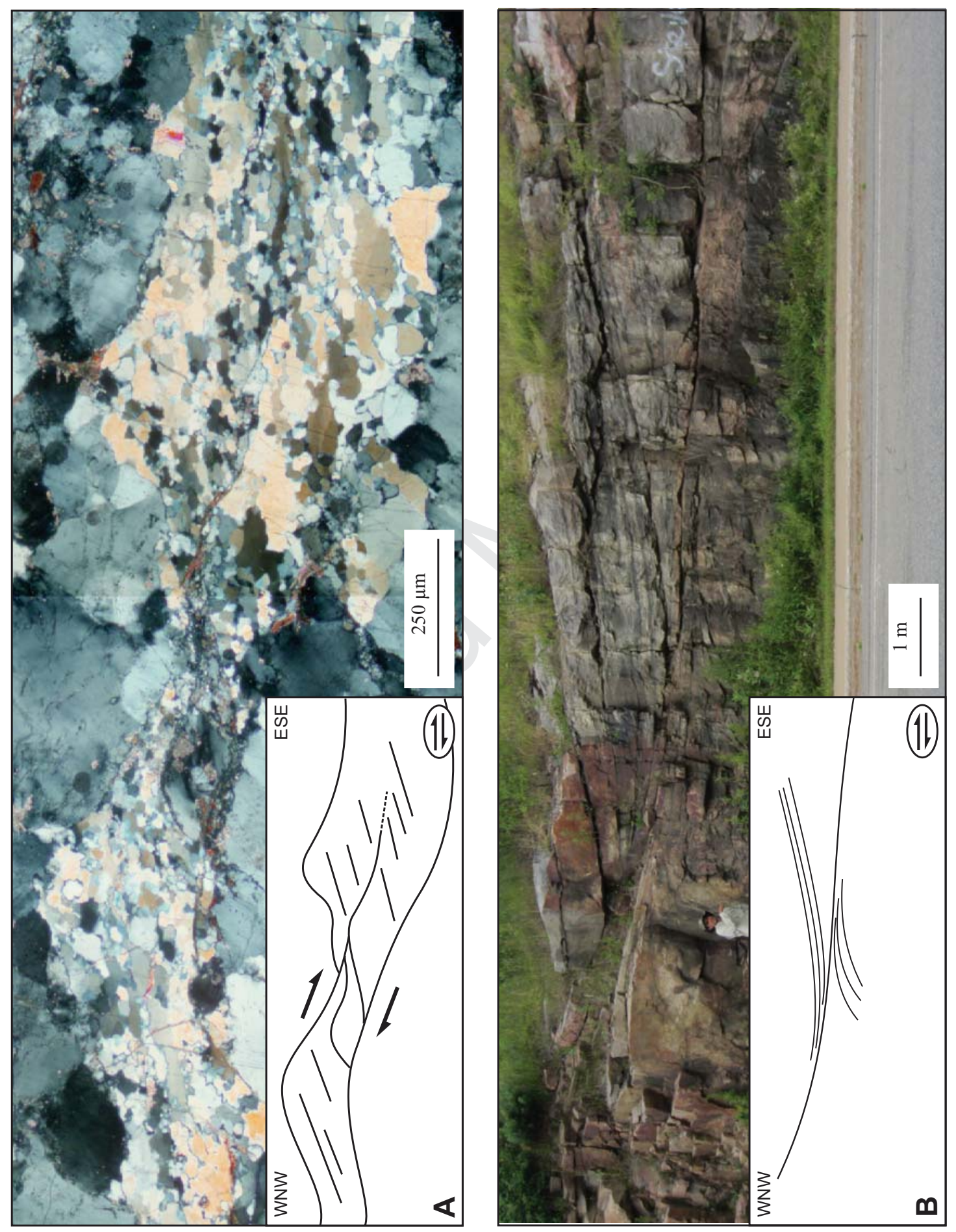
NOTICE: this is the author's version of a work that was accepted for publication in Precambrian Research. Changes resulting from the publishing process, such as peer review, editing, corrections, structural formatting, and other quality control mechanisms may not be reflected in this document. Changes may have been made to this work since it was submitted for publication. A definitive version was subsequently published in Precambrian Research, 257, (Feb 2015). doi: 10.1016/j.precamres.2014.11.012
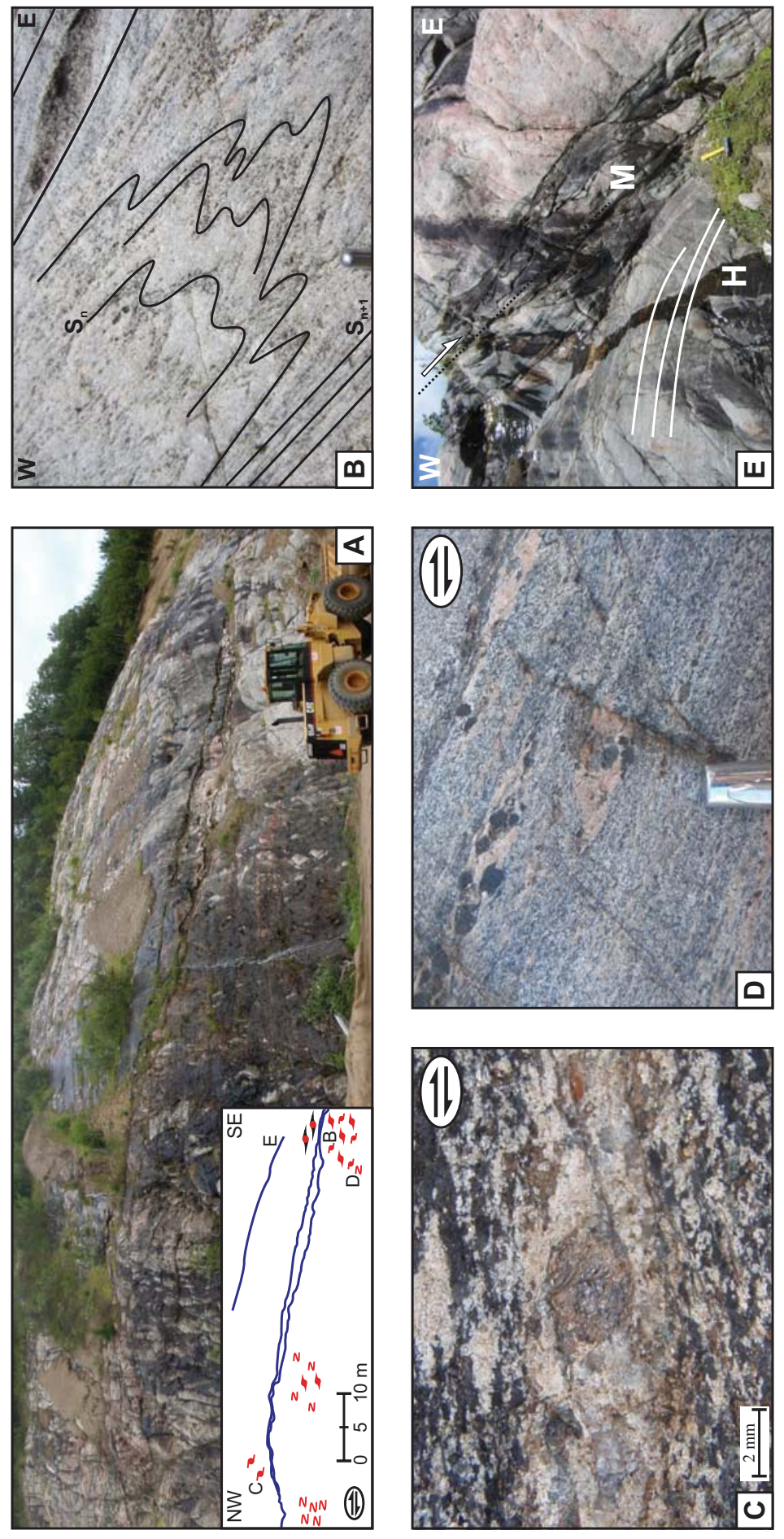

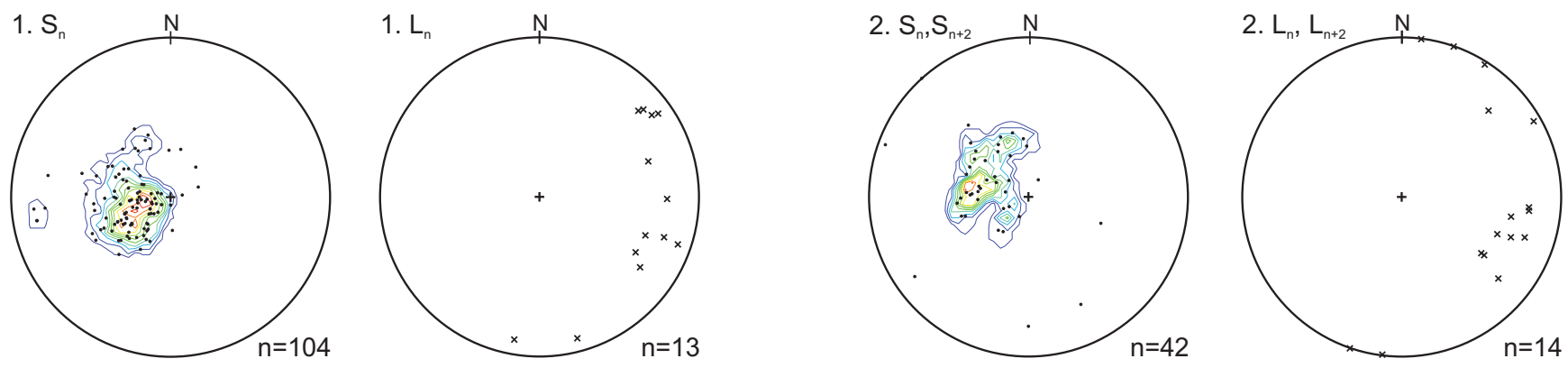

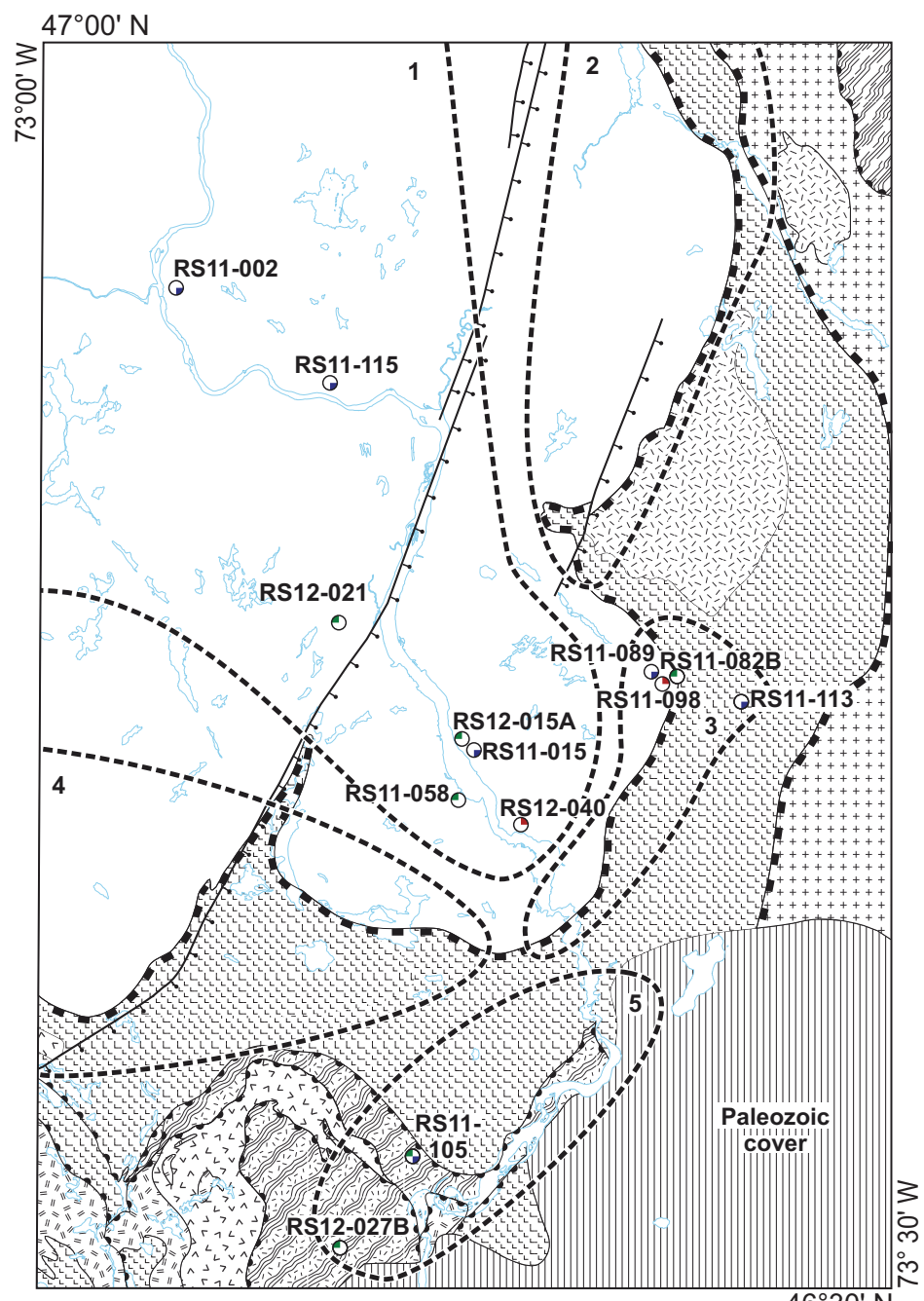

Mékinac-Taureau domain

Mekinac complex

\section{Shawinigan domain}

送湛 Lejeune complex

St. Didace complex

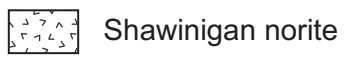

St. Boniface paragneiss

Jésuite complex

\section{Portneuf-Mauricie domain}

++++7
+++++
++++ La Bostonnais complex

Montauban Group
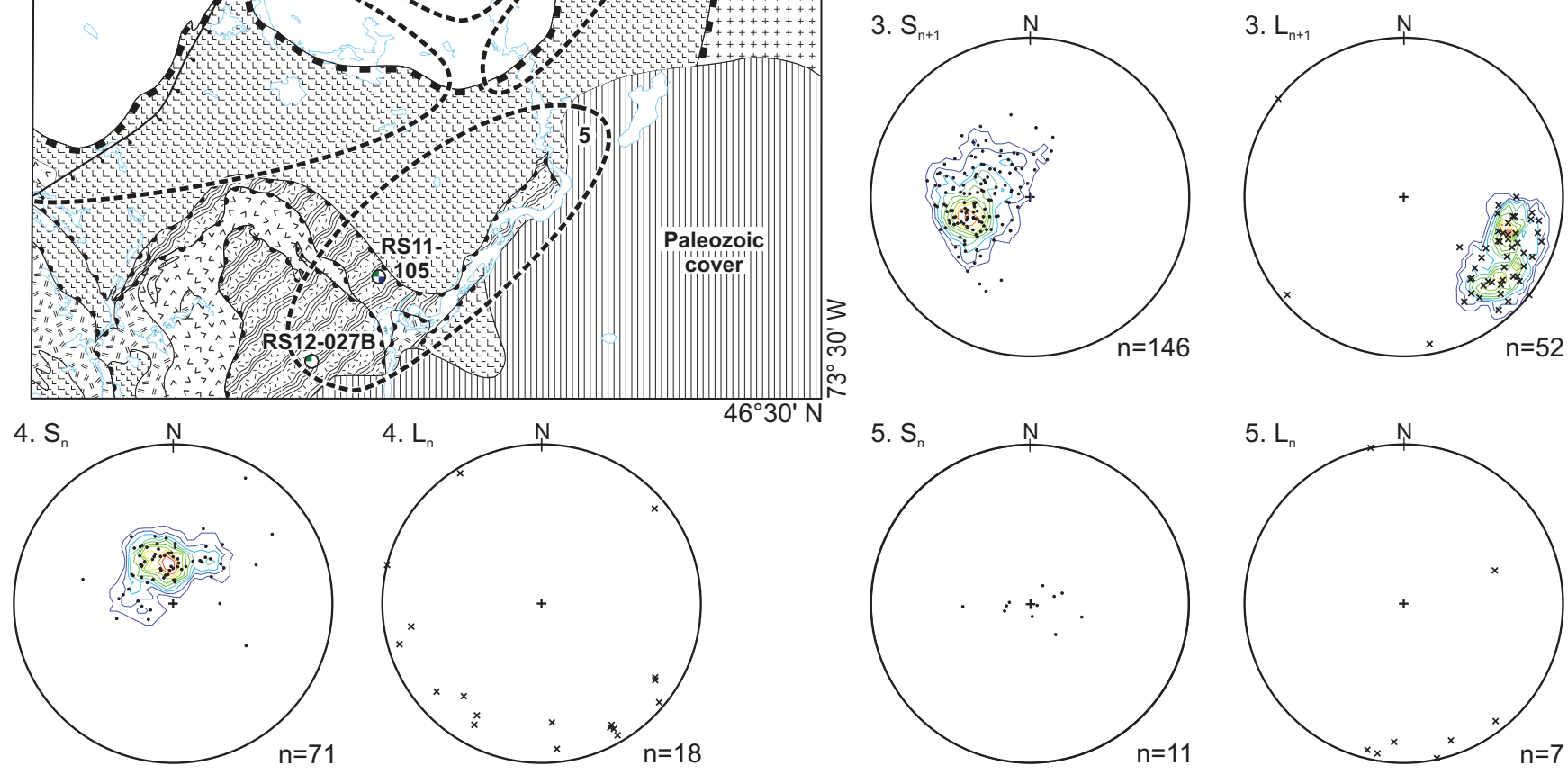

$46^{\circ} 30^{\prime} \mathrm{N}$
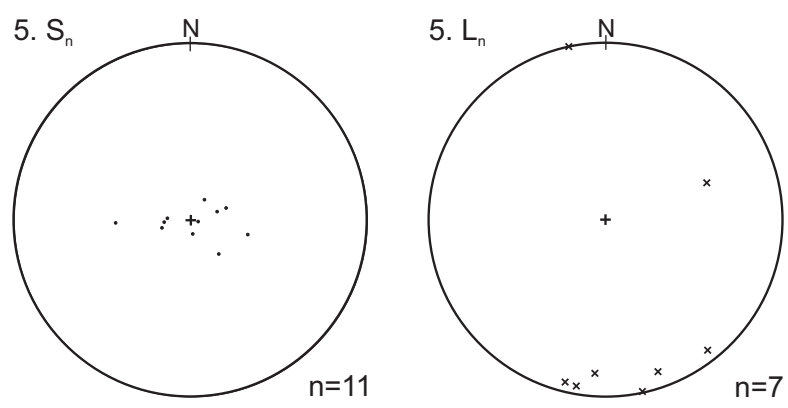

process, such as peer review, editing, corrections, structural formatting, and other quality control mechanisms may not be reflected in this document. Changes may have been made to this work since it was submitted for publication. A definitive version was subsequently published in Precambrian Research, 257, (Feb 2015). doi: 10.1016/j.precamres.2014.11.012

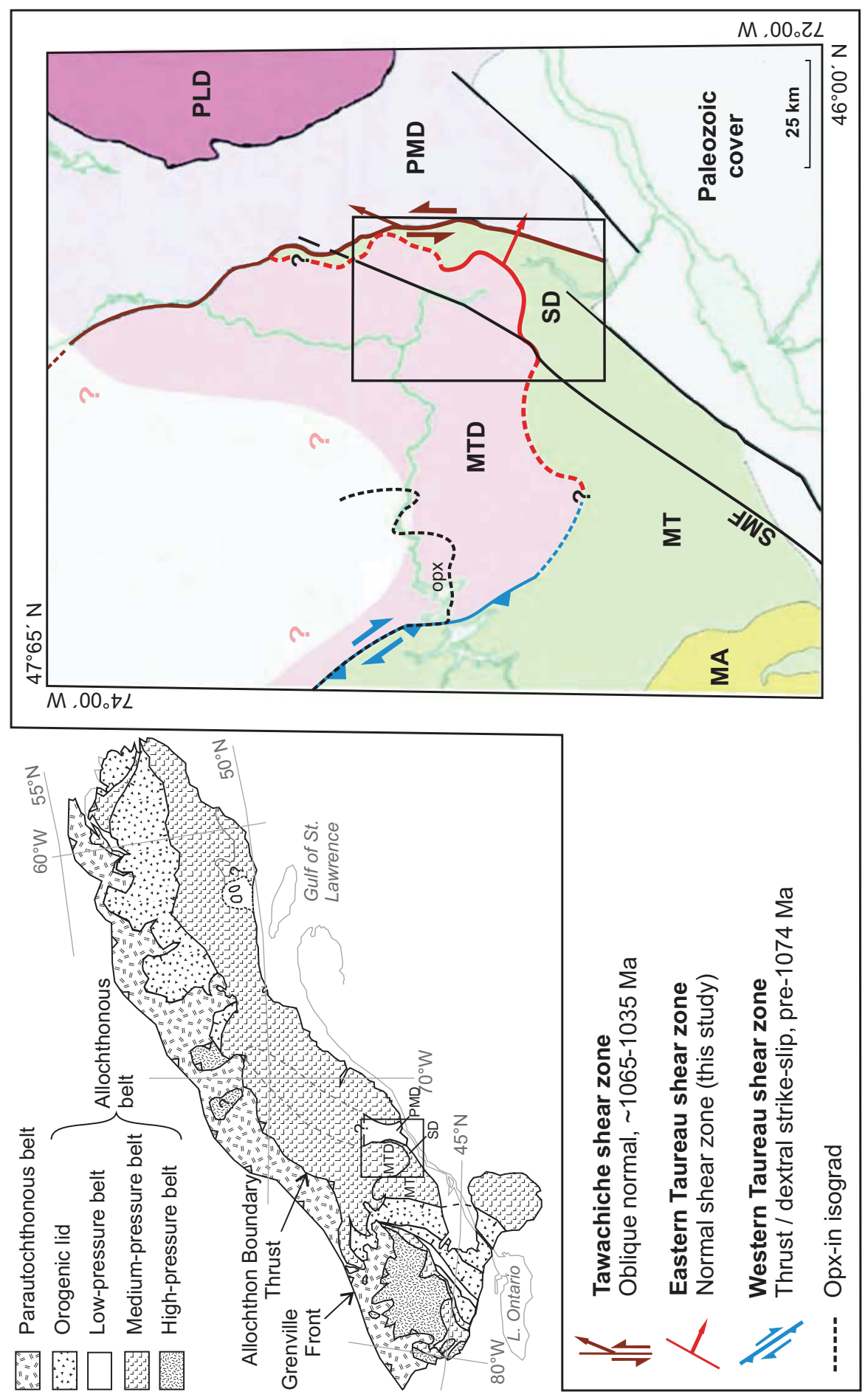

